\title{
Transition from normal to cancerous cell by precancerous niche (PCN) induced chronic cell-matrix stress
}

\author{
Björn L.D.M. Brücher ${ }^{1,2,3, *}$, and Ijaz S. Jamall ${ }^{1,2,4}$ \\ ${ }^{1}$ Theodor-Billroth-Akademie ${ }^{\circledR}$, Germany, USA \\ ${ }^{2}$ INCORE, International Consortium of Research Excellence of the Theodor-Billroth-Academy ${ }^{\circledR}$, Germany, USA \\ ${ }^{3}$ Department of Surgery, Carl-Thiem-Klinikum, Cottbus, Germany \\ ${ }^{4}$ Risk-Based Decisions Inc., Sacramento, CA, USA
}

Received 23 March 2018, Accepted 9 April 2019

\begin{abstract}
The attempt to restore homeostasis, once disrupted, such that complex signaling, crosstalk between ubiquitous proteins, and a diverse range of pathways gone awry is near impossible, especially in the presence of an ongoing pathogenic stimuli with incessant inflammation. This persistent inflammation, when unresolved, induces fibrosis with consequent remodeling of the extracellular matrix (ECM) which leads to the formation of the precancerous niche (PCN), the tipping point in the transition of normal to cancerous cells. Thus, the sustained disruption of homeostasis when confronted with limited adaptation capabilities either of cells or of the surrounding matrix and faced with chronic stress in the tissue microenvironment results in an escape strategy which, if unsuccessful, causes cells, tissue, or the organism to become unable to recover over the long term. All conditions necessary for cell-cell transition such as deregulation of cell-cell complexes, decrease in the stability of adherens junctions, together with the apical-basal polarity, and the loss of the cytoskeletal architecture occurs as a cascade of events inducing inappropriate and diverse signaling pathways and crosstalk. In biology, the transition of one cell type to another and the transition from one cell function to another is incompletely understood mechanistically, but within the context of embryogenesis and morphogenesis is acknowledged as a physiologically routine event. The constant stress that can result in the development of the PCN leads to a chronic stress escape strategy (CSES) which, if unsuccessful, eventually triggers a normal cell- to-cancer cell- transition (NCCCT).
\end{abstract}

Keywords: $\beta$-catenin, AHR, Akt, AP-1, Bcl-2, Cancer, Carcinogenesis, Cell transition, Chronic inflammation, CD44, Cx32, E1Q, E12/E47, EBV, ECM, Extracellular matrix, Epidemiology, Epigenetics, ERK, FADD, Fibrosis, FoxC1, Genomics, GSC, HATs, HGF, LINE-1, microRNA, MMPs, MMP-2, MMP-9, Mutation, NF$\kappa \mathrm{B}$, OSCC, p107, p130, p300, Pathogenesis, PBX, PI3K, PPAR- $\gamma$, Precancerous niche, Proteomics, RB1, RB1CC1, RBL1, SIP1, SP1, Slug, Snail, Somatic mutation theory, SOX, Src, Syk, STAT3, TALE, TCF3, TGF- $\beta 1$, TIMP-1, TNFR1, TRADD, Twist1, VEGF, ZEB1, ZEB2

\section{Introduction}

Cell transition is one of the miracles of biology and occurs by a variety of influences: polarity coordination [1-12], microtubule dynamics [13], various signaling pathway feedback [14] and by factors such as twist-related protein 1 (Twist1), Zinc finger protein SNAI1 (Snail)/zinc finger protein SNAI2 (slug), zinc finger E-box-binding homeobox 1 (ZEB1)/zinc finger E-box-binding homeobox 2 (ZEB2), transcription factor $3\left(\mathrm{TCF}_{3}, \mathrm{E} 2 \mathrm{~A}\right.$ immunoglobulin enhancer-binding factors E12/E47), homeobox protein goosecoid (GSC), and survival of motor neuron proteininteracting protein 1 (SIP1) [15-19]. For example, deletion

*Corresponding author: b-bruecher@gmx.de of Snail or Twist in a genetically engineered mouse model to suppress the epithelial-mesenchymal transition (EMT) showed that Snail2 (Slug) expression was restricted to early pancreatic intraepithelial lesion without affecting the extracellular matrix (ECM) and fibroblast content, tumor vessel density, intratumoral hypoxia, CD3+ T-cell infiltration, and cancer cell apoptosis, and was associated with induction of chemoresistance to gemcitabine [20].

However, cells can switch between different types of polarity and cell transition needs much more to go awry such as "signaling networks, transcription factors, membrane-trafficking pathways" [21].

"The transition from one cell function to another, as well as the transition of one cell type to another seems to be a 
routine event rather than a rare one" [22]. The cell-cell communication as well as of the ECM influences the polarity, and perhaps most importantly, malignant transformation of mammary epithelial cells by alterations of the ECM including the complex interplay of various signaling pathways such as the metalloproteinases (MMPs) and their inhibitors, the tissue inhibitors of metalloproteinases (TIMPs) ([23] reviewed in [24]).

Tissue inhibitor of metalloproteinases-1 (TIMP-1) can induce hepatocyte growth factor (HGF/scatter factor) accompanied by increased metastasis and triggering of its corresponding genes in colorectal cancer metastasis [25]. In this regard, gelatinases are of for cellular homeostasis as well as for metastasis [26]. For example, Helicobacter pylori (H. pylori) infected gastric mucosa increases interleukin 21 (IL-21) and promotes gelatinases, matrix metalloproteinase 2 (MMP-2), and matrix metalloproteinase 9 (MMP-9) synthesis through nuclear factor kappa-lightchain-enhancer of activated B cells (NF- $\kappa \mathrm{B})$ [27]. The disruption in homeostasis by signaling and crosstalk of ubiquitous proteins [28] in the presence of ongoing pathogenic stimuli induces unresolved chronic inflammation which has been reviewed elsewhere in this Special Issue [29, 30].

Cell transition during carcinogenesis is difficult to break down to just a few signaling pathways, receptors, or cell types. Some specific pathways might be differently affected and/or dependent on other influences, e.g., some signaling will occur during embryology (normal physiology) or influenced by ongoing pathogenic stimulus while different changes in homeostasis may provoke different effects. These may be the reasons why cell transition in general is restricted and why it is necessary to understand in all its complexity. Here we provide information on cell transition with regard to embryology, pathogenic stimulus, the role of the retinoblastoma (RB) protein family and apoptosis, chronic inflammation, and the role of the retinoblastoma coiled coil protein 1 (RB1CC1), fibrosis and its remodeling, all working towards the precancerous niche (PCN). In addition, various signaling pathways such as pituitary tumor transforming gene 1 (PTTG1), catenin beta-1 ( $\beta$-catenin), sex-determining region Y (Sry)-related high-mobility-group Box (SOX), microRNAs, histone acetyltransferase p300 (p300, adenovirus early region 1A (E1A)-associated protein p300), specificity protein 1 (transcription factor) (SP1), activator protein 1 (AP-1), aryl hydrocarbon receptor (AHR), long interspersed nuclear element-1 (LINE1) and chronic cell matrix stress including STE20-like serine/ threonine-protein kinase (SLK) signaling provide insights that are helpful to review so as to unmask the process of cell transition during carcinogenesis.

\section{Embryology}

Cell transition is absolutely necessary for embryogenesis and morphogenesis but incompletely understood. However, the "transition from one cell function to another, as well as the transition of one cell type to another seems to be a routine event rather than a rare one" [22, 31]. For example, some 50 years ago it was shown that free-floating "peritoneal macrophages" replaced destroyed mesothelial cells via transformation of its original macrophage role to that of mesothelial cells [32,33]. Chronic lung injury, under some circumstances, can result in transition to cancer [34]. An EMT in embryogenesis/morphogenesis acts in a direction opposite to that of a mesenchymal-epithelial transition (MET) [35]. EMT can induce non-cancer stem cells to become cancer stem cells [36, 37].

Mammalian morphogenesis is complex. The enzymes histone deacetylases (HDACs) remove acetyl groups to promote chromatin compaction ([38] reviewed in [39]) and contain 11 enzymes grouped into four classes: class I (Hdac1, Hdac2, Hdac3, and Hdac8), IIa (Hdac4, Hdac5, Hdac7, and Hdac9), IIb (Hdac 6 and 10), and IV (Hdac11) ([30] reviewed in [40]). HDACs counteract the promoting effect of histone acetylation on gene expression which is to catalyze an acetyl group to certain lysines in the tails of the core histones $\mathrm{H} 2 \mathrm{~A}, \mathrm{H} 2 \mathrm{~B}, \mathrm{H} 3$, and $\mathrm{H} 4$ by histone acetyltransferases (HATs) [39].

HDAC8 is involved in tissue development [39] and in various diseases. HDAC8 is increased in lung fibrosis and anti-HDAC8 therapy decreases type- 1 collagen and fibronectin while increasing the anti-fibrotic peroxisome proliferator-activated receptor gamma (PPAR- $\gamma$ ) [41] and is associated with poor survival in neuroblastoma [42]. HDAC8 knockdown decreases cell proliferation in lung, colon, and cervical cancer cell lines [43]. Furthermore, AHR and HDAC8 are enhanced in liver cancer cell lines and tissues, and HDAC8 inhibition upregulates the cyclin D-retinoblastoma protein $(\mathrm{RB}, \mathrm{RB} 1)$ in vitro and in vivo through AHR [44].

\section{Pathogenic stimulus}

Normal to metaplastic gastric epithelial cell proliferation is coordinated by hyaluronic acid cluster-ofdifferentiation (CD) cell surface glycoprotein (CD44) receptor in H. pylori- or tamoxifen-induced atrophy of acidsecreting parietal cells (PCs) [45]. Cell damage induces extracellular signal-regulated kinases (ERK, mitogenactivated protein kinase [MAPK]) signaling resulting in an increase in CD44 which then binds to signal transducer and activator of transcription 3 (STAT3) and reduces the proliferation response. CD44 is encoded by one gene on chromosome 11 [46] and consists of a constant part encoded by exon 1-5 and 16-20 which are included in all isoforms; $\mathrm{N}$ - and O-glycosylation increases CD44 heterogeneity and CD44 is synonymous with a large transmembranous proteoglycan surface molecule family.

Transforming growth factor $\beta 1$ (TGF- $\beta 1$ ) increases CD44 and down-regulates microRNA-138 contributing to cell transition [47]. Snail expression and partially Twist1 induce in a $\beta$-catenin-dependent manner CD44 expression [48]. Epstein-Barr virus (EBV) promotes latent membrane protein 1 (LMP1) introducing CD44 expression on the cell surface associated with lymphoid tumor growth and dissemination [49] and the EBV-CD44 axis is of importance 
in oral squamous cell carcinoma (OSCC) and nasopharyngeal carcinoma (NPC) [50], gastric cancer [51, 52] and Burkitt lymphoma [53].

In vitro experiments of EBV associated keratitis show that transforming growth factor beta 1 (TGF- $\beta 1$ ) promotes spleen tyrosine kinase (Syk) and proto-oncogene tyrosineprotein kinase $(\mathrm{Src})$ signaling after phosphatidylinositide 3-kinase (PI3K)/protein kinase B (Akt) and ERK activation resulting in cell transition in human corneal epithelial cells (HCECs) [54] which may be seen as an ignition point for cell-to-cell transition.

The association between pre-B-cell leukemia transcription factor homeobox (PBX) with PBX1-4 in human and H. pylori is of interest: H. pylori increases the transcriptional factor PBX1 followed by downregulation of connexin 32 (Cx32) [55]. Decreased Cx32 is correlated with "the degree of tumor cell differentiation with unrestricted growth control' ([56] reviewed in [55]).

Three amino acid extension loop proteins (TALE) play a role in cell differentiation and embryogenesis and include the trimeric DNA-binding complexes of PBX, the regulating protein-1-2 of the Homebox gene (Hox) with PBX/ Knotted 1 Homeobox 1 (PKNOX1), PKNOX1-2, PBXregulating protein-1-2 (PREP1-2), the DNA binding cofactors MEINOX (a contraction of MEIS and KNOX) for PBX and Hox with myeloid ecotropic viral integration site1-3 (homebox protein Meis1-3) [57-59]. However, these transcription factors interact independently in addition to being integrated into multiple pathways. For example, Meis1 acts as a purported oncogene, promoting cell proliferation and resistance to apoptosis, and was reported to be highly expressed in ovarian cancer [60].

Amplification of the Meis1 gene was reported in acute myeloid leukemias [61], neuroblastoma ([62] reviewed in [59]). Transcriptome analysis suggested that Meis1 was thought to be involved in carcinogenesis of colorectal adenomas [63]. Splice variants of Meis1 containing Meis1a and Meis1b found in human and mice and two new Meis1d transcripts were found with $27 \mathrm{kD}$ weight $\left(\mathrm{Meis}_{27}\right)$ in cytoplasm of proximal colon epithelial cells and the Meis1 $32 \mathrm{kD}$ variant $\left(\mathrm{Meis}_{32}\right)$ in the nuclei of non-epithelial cells in the stomach and colon; finding various Meis1 variants in different cell types and subcellular compartments [64]. This may explain the contradictory findings that Meis1D, the homeodomain-less splice variant of Meis1, is found to inhibit gastric [65] and clear renal cell carcinogenesis [66], or to be downregulated in colorectal carcinomas, suggesting that Meis1D is a tumor suppressor [64].

The pioneer transcription factor PBX1 cannot promote carcinogenesis by itself. In esophageal cancer tissues, the transcription factors, Forkhead box C1 (FoxC1) and ZEB2, are associated with both poor survival and diseasefree survival: FoxC1 transactivates ZEB2, which also suppresses E-Cadherin, through PBX1, which is a member of the three TALE-class homeodomain families [67]. The TALE homeodomain of PBX1 promotes cell transition in animals and plants [68] and in gastric cancer [69, 70].

Furthermore, the transcription factor, PREP1, also posseses tumor suppressor activity and both PREP-1 and
Meis1 require PBX1 with the effect being largely dependent on the level of expression. An increase in expression of PREP1 results in inhibition of Meis1-triggered tumor development but other genes such as AP-1 sequences are associated with Meis1-induced cancer. Blasi et al. reviewed the different PREP1 suppressive and Meis1 oncogenic signatures [59]. PREP1, Meis1, and PBX1 single nucleotides can be found in cancers and, the absence of PREP1, induces DNA damage. The fact that TALE gene amplifications are not frequent in that only $5 / 287$ gastric cancer patients showed a deletion with one patient showing a truncating mutation in PREB1 also suggests that Meis1 alterations are also not very common and reported in 14/178 lung squamous cell carcinomas. This may be due to the fact that the majority of mutations occur after the onset of carcinogenesis as previously proposed [22].

It appears that both PREP1 and Meis1 compete in terms of their suppressive and oncogenic effects in carcinogenesis [59]. This might be relevant since different cancer phenotypes might be dependent on the kind and grade of disruption of their homeostasis at different points in the pathways. PREP1 has been associated with induction of cell transition and cancer spread through the TGF- $\beta$ / SMAD3 pathway in non-small cell lung carcinoma (NSCLC) [71]. As Meis1 was reported to induce G1/2 arrests and non-apoptotic cell death through decreased levels of Survivin and B-cell lymphoma 2 (Bcl-2) [66], its non-oncogene effect might be a matter of concentration which, in turn, argues in favor of the disruption-of-homeostasis concept in carcinogenesis. Meis1 associated cell growth promotion is directly linked to RB1 cell-cycle signaling [72].

\section{Retinoblastoma (RB) protein family}

The RB protein family contains the tumor suppressor $\mathrm{RB} 1$, the retinoblastoma-like protein 1 (p107, RBL1), and the retinoblastoma-like protein 2 (p130, RBL2) [73]. RB1 can be inactivated by phosphorylation resulting in cell cycle progression. It is important to note that Rb1 has independent cellular functions depending on its being un-phosphorylated, mono-phosphorylated, or hyperphosphorylated [74-77]. This condition is also independent from Myc amplification [78]. RB1 binds and inactivates the transcription factors E2 promoter-binding-protein-dimerization partner (E2F-DP) dimers and thus prevents cell cycle progression [79]. This explains why the majority of human OSCC do not express RB1 measured by immunohistochemistry, and that those which express RB1 (some 20\%) reveal the inactive (phosphorylated) form [80].

EBV infection is inversely correlated with the expression of RB1 in Reed-Sternberg cells in classic Hodgkin lymphoma [81] and RB2/p130 was inversely correlated with vascular endothelial growth factor (VEGF) expression and tumor aggressiveness in cyclin-dependent kinase inhibitor 1B (p2 $7^{\mathrm{KIP} 1}$ )-negative hepatocellular carcinoma (HCC) patients and both were independent of tumor staging [82]. An inverse correlation of retinoblastoma protein was observed in head and neck squamous cell carcinoma [83]. 
Otherwise, it should be noted that the retinoblastoma protein $2(\mathrm{RB} 2) / \mathrm{p} 130$ immunohistochemistry (IHC) false positive rate can be as high as $22 \%$ [84] and that RB1 degradation by the human papillomavirus (HPV) E7 of the HPV type 16 might overcome the cellular response in high-risk HPV [85]. The necessity of zinc which has been reviewed in this Special Issue in various signaling pathways is also of importance as the E7 carboxyl terminus consists of a zinc-binding motif [86]. HPV E7 proteins even stimulate proliferation independently of their ability to interact with RB [87]. HPV E6/7 proteins can induce a decrease of the human suppressor protein 53 (p53) but also interact by p53 independent pathways inducing apoptosis [88].

\section{Apoptosis}

The self-induced death of cells called apoptosis involves "typical morphological features, such as shrinkage of the cell, fragmentation into membrane-bound apoptotic bodies and rapid phagocytosis by neighbouring cells" and chromatin condensation, membrane blebbing or ultrastructural modification of cytoplasmic organelles along with activation or suppression of specific signaling and crosstalk pathways [89-92]. At first, it was thought that apoptosis occurs spontaneously in cancers and was largely associated with anti-cancer treatment [93] but there is a difference in apoptosis in existing cancer compared to the development of a cancer cell (carcinogenesis) as here it is not just about how the double-strand cleavage of nuclear DNA occurs.

We now recognize the importance of the interruption of signaling pathways and decreased apoptosis, which typically is necessary for maintaining and regulating homeostasis of chronic cell stress matrix cells. Furthermore, decreased apoptosis is important during carcinogenesis [94]. Most important in the apoptotic process are caspases [95] but also caspase-independent pathways [96, 97] and the interplay between various extrinsic receptors, such as the death type 1 TNF receptor (TNFR1), TNF receptor-associated death domain (TRADD), Fas-associated death domain (FADD), as well as cysteine proteases like caspase 8 , and intrinsic pro-apoptotic proteins and the homeostasis between pro-apoptotic proteins Bax, Bak, Bad, Bcl-Xs, Bid, Bik, BIM and Hrk, and anti-apoptotic proteins Bcl-2, Bcl-XL, Bcl-W, Bfl-1 and Mcl-1 ([95, 98, 99] reviewed in [94]).

\section{Chronic inflammation}

The extensive review of chronic inflammation triggered by pathogenic biological and/or chemical stimulus is presented elsewhere in this Special Issue [29]. Chronic pancreatitis with chronic inflammation is a well-known precancerous condition $[100,101]$ and the important role of TGF- $\beta 1$ had been discussed [29].

TGF- $\beta 1$ induces lysyl oxidase (LOX) expression, secretion, and proteolytic processing in normal as well as in mammary epithelial cells and LOX downregulates the E-cadherin suppressive effect [102] while upregulating vimentin $[103,104]$. Both the upregulation of vimentin and the downregulation of E-Cadherin were observed at the mRNA level [104].

Chronic inflammation in mice and human colitis causes inactivation of retinoblastoma protein by hyperphosphorylation with consequent increase of cell proliferation [105]. Furthermore, dietaryinduced obesity in rats results in the downregulation of RB1 [106]. HPV proteins E6 ad E7 bind and inactivate p53 and RB1 [107] and HPV decreases E-cadherin and downregulates RB1, and interestingly, EBV seems to act as a co-factor [108]. The coinfection of H. pylori and EBV was reported to increase chronic inflammation being of importance for the severity of gastritis in young patients as well as for the development of gastric carcinogenesis $[109,110]$.

RB1CC1 is regulator of cell differentiation and proliferation and modulates TGF- $\beta$ signaling through the RINGtype E3 ubiquitin ligase, Arkadia [111].

\section{Retinoblastoma coiled coil protein 1 (RB1CC1)}

$\mathrm{RB} 1 \mathrm{CC} 1$ is closely related to $\mathrm{RB} 1$ expression in various epithelial and mesenchymal cancers [112, 113]. RB1CC1 is correlated with RB1, and RB1CC1 seems to be a RB1 regulator [114]. Furthermore, RB1CC1expression induces pancreatic stellate cells (PSCs) and correlates with pancreatic fibrogenesis [115]. RB1CC1 knockdown decreases alpha smooth muscle actin $(\alpha$-SMAD), collagen expression and autophagy with consequent inhibition of pancreatic duct ligation-induced pancreatic fibrosis while RB1CC1triggered autophagy induces PSC activation and pancreatic fibrogenesis in chronic pancreatitis. Comparing human OSCC progression with a mouse model revealed an increase of TGF- $\beta 1$, N-cadherin, p53 and RB1CC1 with a decrease of E-cadherin from normal oral mucosa to OSCC while it was "increased in lymph node metastases in both human and mouse samples" [116]. It was also shown that "altered ductal carcinoma in situ (DCIS)- associated myoepithelial cells promote the invasive progression of DCIS into invasive ductal carcinoma (IDC) via TGF- $\beta$ signaling activation" [117]. Only some $8 \%$ of 169 investigated DCIS cases showed an aberrant molecular alteration.

\section{Fibrosis and its remodeling resulting into the precancerous niche (PCN)}

The role of remodeled fibrosis in creating the PCN has been reviewed separately in this Special Issue [118]. The decrease of E-Cadherin contemporaneously with ECM degradation appears to be relevant for transition of a normal cell to a cancer cell. The subunit enhancer of the zeste homolog 2 (EZH2) of Polycomb Repressive Complex 2 (PRC2), a complex with histone methyltransferase activity, results in increased expressions of Snail, Slug and vimentin with decreased E-Cadherin expression, and is associated with increased fibrosis together with ECM destruction, 
plasminogen activation, downregulating of adherens junctions, and increased cell transition [119]. Inhibiting EZH2 with 3-Deazaneplanocin A (DZNep) results in the inhibition of growth and reduced fibrosis in endometriosis along with an attenuated EMT.

It has been suggested that all LOX family members, but especially lysyl oxidase-like-2 (LOXL2), can facilitate cell transition from normal to cancer as LOXL2 can stabilize Snail and repress E-cadherin, occludin, and estrogen receptor- $\alpha$, and up-regulate vimentin, fibronectin, and matrix metalloproteinase-14 (MMP-14, MT1-MMP) [103, 104, 120-122]. LOXL2 is thought to induce cell transition via focal adhesion kinase (FAK)/Src signaling [123] in gastric [124], breast [125], and pancreatic cancer [104, 126].

In human breast cancer cells (MDA-MB231), LOXL2 was shown to be inhibited by the flavone 5,6,7-trihydroxyflavone (baicalein) through the primary inhibition of of cysteine-rich protein 61 (CCN1/Cyr61) which weakened the LOXL2-Snail or-Slug interplay and resulted in a subsequent increase of glycogen synthase kinase $3 \beta$ (GSK-3 $\beta$ )-dependent Snail and Slug degradation, and the decrease of migration and invasion [127]. LOX activates FAK/Src signaling as well as Snail [104, 123, 128] and FAK/Src signaling promotes cell transition [129]. Furthermore, LOXL2 attenuates GSK-3 $\beta$ induced phosphorylation of Snail [120].

LOX phosphorylates p130(Cas) (breast cancer antiestrogen resistance protein 1, BCAR1) resulting in the formation of $\mathrm{p} 130$ (Cas)/adaptor protein $\mathrm{Crk} /$ dedicator of cytokinesis (DOCK180) signaling complex while increasing Rac and cdk42 activity regulating actin filament formation with an increase of the cytoskeleton protein, lamellipodium [123]. Lamellipodium is a myosin-independent mechanosensor [130] that drives cell migration in many normal and pathological conditions [131] and is promoted by Rac [132].

The FAK/p130(Cas)/Rac/lamellipodin complex transduces signaling information from matrix stiffnes into mechanosensitive cell cycling and "converts external information encoded by ECM stiffness into stable intracellular stiffness and mechanosensitive cell cycling" and, therefore, has an effect on cell migration as well as on the regulation of the cell cycle [133].

Snail promotes cell transition in a SMAD3/STAT3dependent manner in chronic pancreatitis associated with diabetes [134]. LOXL2 drives EMT through the inositolrequiring enzyme 1 (IRE1)/X-box binding protein 1 (XBP1) signaling pathway inducing Snail, Slug, ZEB2, $\mathrm{TCF}_{3}$ which are all direct transcriptional targets of XBP1 [135]. Snail and Slug downregulate E-Cadherin. Loss of Ecadherin expression was associated with cell transition in esophageal spindle cell carcinoma which may trigger Snail neoexpression while N-cadherin appears to be of lesser importance in the pathogenesis of this tumor type [136].

Upregulation of TGF- $\beta$ driven Wnt inhibitors e.g., Wnt family member 5a (WNT5A), Dickkopf Wnt signaling pathway inhibitor (DKK) 1 and 3, and genes involved in modulation of ECM, including LOX, collagen type V alpha (COL5A1), and thrombospondin 1 (THBS1) showed a more aggressive malignant melanoma phenotype [137]. Interestingly, the antibiotic, salinomycin, inhibits cell transition by downregulation of Wnt/catenin beta- 1 ( $\beta$-catenin) signaling [138].

Bleomycin induces collagen I synthesis in pleural mesothelial cells with increases of vimentin and $\alpha$-SMAD and decreases in E-Cadherin by TGF- $\beta 1 / \mathrm{Smad} 2 / 3$ signaling with associated cell transition [139]. Activating the complex consisting of TGF- $\beta 1$, lectin-like oxidized low density lipoprotein receptor-1, and krüppel-like factor 6 (KLF6), in lung tissues of diabetic patients results in increased cell transition along with pulmonary fibrosis [140]. A role for $N$-acetyl glucosaminyl transferase during cell transition induced by TGF- $\beta 1$ signaling was reported [141]. More recently, it has been shown that this occurs via downregulation of non-muscle myosin II-A through c-Jun $N$-terminal kinase (JNK)/P38 mitogen-activated protein kinase (P38)/ PI3K pathway in lung cancer [142].

Stiff, but not soft, fibronectin substrates induce cell transition dependent on a contractile phenotype with TGF- $\beta$ activation [143]. Matrix stiffness promotes Twist1 release from the cytoplasmic binding partner Ras GTPase-activating protein-binding protein 2 (G3BP2) with nuclear Twist1 translocation. Twist1/G3BP2 signaling responds to biomechanical signaling from the microenvironment with invasion and tumor spread and drives cell transition and metastasis [144]. The pro-inflammatory mediator, interleukin 6 (IL-6), enhances Twist1 in fibroblasts and STAT3 phosphorylation with consequent cancer-associated fribroblast transdifferentiation [145, 146]. Furthermore, Twist1 upregulates the nuclear transcriptor protein paired related homeobox 1 (Prrx1) which increases the glycoprotein Tenascin-C (TNC) with consequent positive feedback loop (PFL) by enhancing Twist1 again. The continous Twist1-Prrx1-TNC PFL interaction results in fibrosis in vivo in fibrotic disease and cancer-assosicated stroma and this positive feedback loop can become irreversibly activated [146, 147].

Many other enzymes and proteins are involved in cell transition, such as PTTG1, $\beta$-catenin (Catenin beta-1, called armadillo in drosophila), SOX, microRNAs (miRs), p300, SP1, AP-1, AHR, and long interspersed nuclear element-1 (LINE1).

\section{Pituitary tumor transforming gene1 (PTTG1)}

The highly aggressive castration-resistant prostate cancers (CRPC) grow outside the prostate into adjacent tissues or metastasize (mCRPC) early with a 5-year survival rate of between 15 and $30 \%$ [148, 149]. PTTG1 is upregulated in cancers such as colorectal cancer [150] and CRPC and regulated by IL-6/STAT3 promoting cell transition [151].

In another endocrine tumor, breast cancer, PTTG1 was increased in recurred estrogen receptor positive (ERpositive) breast cancers ([152] reviewed in [151]). Ionization radiation can induce senescence in PTTG1-depleted cancer cells $[153,154]$ and can suppress cancer cell proliferation by induction of cellular senescence; inhibiting autophagy can result in a "switch from radiation-induced senescence to apoptosis" [155]. 


\section{$\beta$-catenin}

$\beta$-catenin (Catenin beta-1, called armadillo in drosophila) was discovered in the 1980s and is a member of the catenin protein family and a subunit of the $\mathrm{Ca}^{2+}$ dependent transmembrane cadherin complex $([156,157]$ reviewed in [158]). It is involved in the $\beta$-catenin dependent (canonical Wnt) and -independent (non-canonical Wnt) signaling pathways [159]. $\beta$-catenin has tumor characteristics, triggers cancer cell proliferation [160], and is expressed in breast cancer [161], liver [162], colorectal [163], melanoma [164] and leukemia [165].

Dicer, an endoribonuclease, discovered in 2001 [166], is downregulated by $\beta$-catenin and reported as a marker for cancer aggressiveness which appears to facilitate the spread of ovarian cancer [167].

The canonical Wnt/ $\beta$-catenin signaling is co-activated by Smad 2 through the histone acetyltransferase activity of p300 [168].

\section{Sry-related high-mobility-group Box (SOX) imbalance (Fig. 1)}

SOX factors are regulators of transcription and multiple SOX factors have been reported in mammals in nearly every tissue [169]. The functions of SOX genes, including a phylogenetic study of the SOX family and its role in evolution, have been extensively reviewed [170]. SOX4 is a transcriptional factor expressed in B- and T-lymphocytes involved in embryonic development, but its function in apoptosis and cell fate is not completely understood. SOX4 is necessary during organogenesis of the heart, pancreas, and brain and SOX4 regulates EMT by controlling Ezh2 expression and epigenetic reprogramming [171]. Elevated SOX4 levels were associated with poor outcomes in colon cancer [172], gastric cancer [173], lung cancer [174] and osteosarcoma [175].

miR204 was shown to directly target SOX4 in human renal cancer cells suggesting that it could be a marker for the early detection of metastases [176]. Downregulation of SOX1 was associated with improved survival in HCC suggesting that the imbalance of SOX plays a role in the development of cancer [177].

\section{microRNAs (Fig. 1)}

microRNAs (miRNAs) are small non-coding RNA regulating genes in plants, animals and in some viruses and many miRNAs have been observed in association with cancer [178]. miR204 expression was reported as being lower in H. pylori- positive gastric mucosal tissue [179]. miR204 directly targets SOX4 and suppress both proliferation and metastasis of gastric cancer AGS cells. miR-204 is not associated with lymph node metastasis or early tumor stages whereas SOX4 was shown to be associated with lymph node metastasis and advanced tumor stages $[173,180]$. miR204 is downregulated in severe $H$. pylori associated gastritis as well as H. pylori-positive gastric cancer cells, and in a transfection model with hsa-miR-204 mimic/inhibitor oligonucleotides in human gastric cancer cell lines, SGC-7901 and MKN-45, cells suppresses in vitro migration/invasion and proliferation of gastric cancer cells [180]. This may explain why an inverse correlation of miRNA204 with SOX4 was reported viz., higher SOX4 is associated with lower miRNA204 and vice versa and miRNA204 directly targets SOX4.

miR-503 directly targets Cyclin D1 and functions as a tumor suppressor as it reduces Cyclin D1 expression [181] which might be of therapeutic value as high Cyclin D1 levels were associated with decreased survival and higher recurrence rates in esophageal squamous cell carcinoma (ESCC) [182].

miR21 is a regulator of mesenchymal phenotype transition which is triggered by TGF- $\beta$ [183]. Early fibrosis in chronic obstructive pulmonary disease (COPD) patients shows increased miR21 levels [184]. Increased miR21 levels also result in a decrease of the TGF- $\beta 1$ regulator Smad7 and this deregulation enhances $\alpha$ SMA-mRNA, protein levels, and collagen accumulation [185].

Programmed cell death protein $4(\operatorname{Pdcd} 4)$ interferes with JNK-mediated phosphorylation of c-Jun and recruitment of the coactivator p300 by c-Jun [186]. miR21 downstream of the tumor suppressor, Pdcd4, results in increased cancer invasion and spread [187, 188]. The disruption of miR21 homeostasis can be seen as miR21 inhibits Smad7 resulting in the withdrawal of the otherwise available negative feedback regulation of TGF- $\beta 1$ [189] miR21 represses the tumor suppressor phosphatase and tensin homolog (PTEN) [190] and inhibits protein BTG2 (Btg2), protein sprouty homolog 1 (SPRY1), and protein sprouty homolog 1 (SPRY2) that usually negatively regulate the RAS/ MAPK/Erk pathway [191] such that in the end the RAS/MAPK/Erk signaling is enhanced. However, the global dysregulation of the microRNA network is more complex than discussed here and much remains to be elucidated in vivo $[182,192]$.

\section{p300 (Fig. 1)}

The enzyme, p300 (synonym: histone acetyltransferase p300, E1A-associated protein p300, EP300), discovered in 1994 [193], is a transcription promoter catalyzing histone acetylation via its histone acetyltransferase activity [194]. p300 and related cyclic adenosine monophosphate (cAMP)-response element-binding-protein was suggested to be "molecular interpreters" that can parse and/or conjugate the regulatory "words," "phrases," and "sentences" of the genome" [195]. p300 is involved in TGF- $\beta$ /Smad mediated alpha 2(I) collagen expression [196] as well as in glomerulonephritis in a pSmad2/3 dependent manner [197].

p300 and had been reported in cancers of the breast [198], lung [199], colon [200], prostate [201] and in leukemia ([202] reviewed in [194]). However, its role depends on which cell lines and/or tissue and/or medium is being examined, the method by which p300 is measured, and even if 


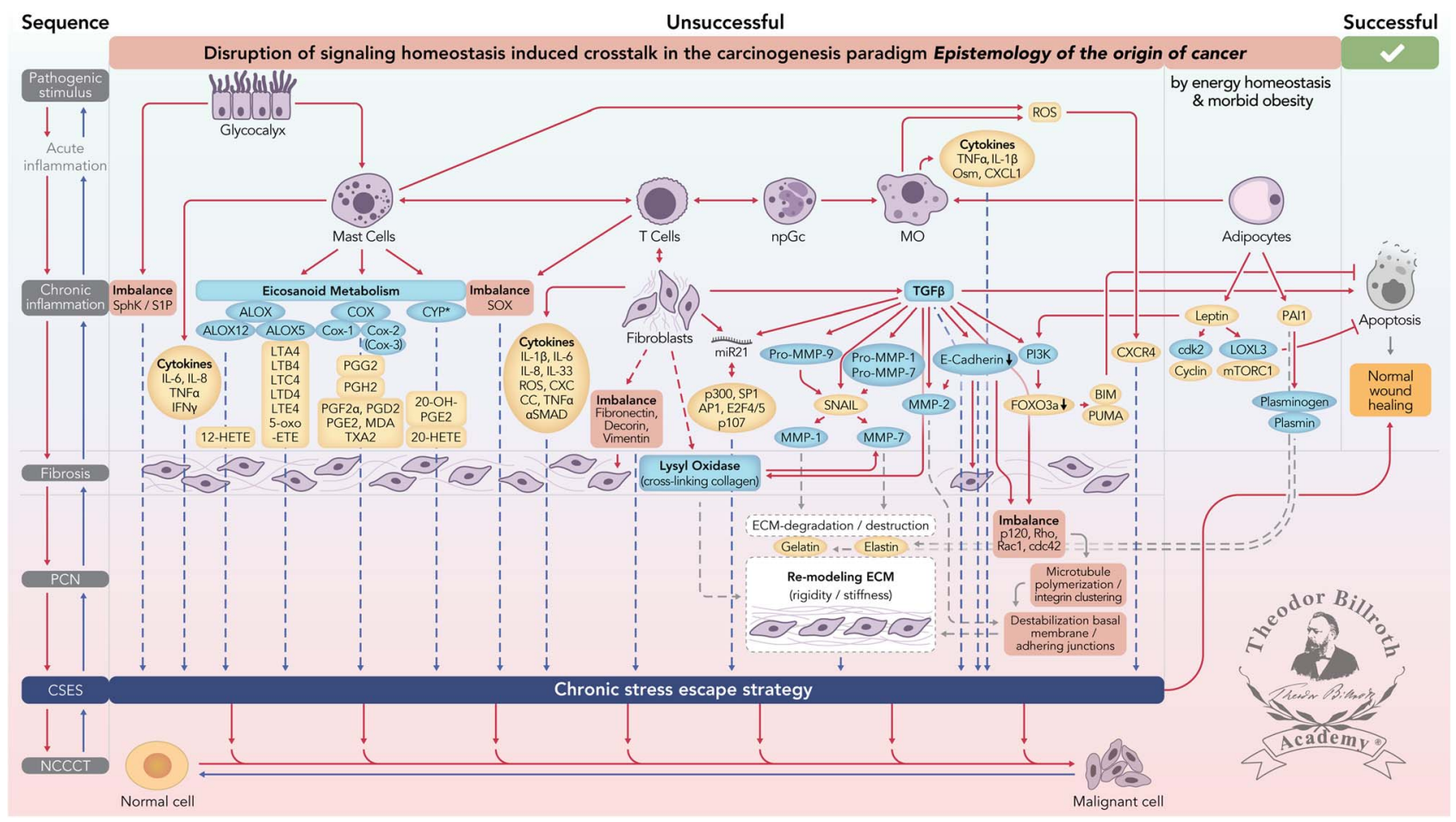

Figure 1. Disruption of signaling homeostasis induced crosstalk in the carcinogenesis paradigm "Epistemology of the origin of cancer". Simplified scheme of the Disruption of signaling homeostasis induced crosstalk in the carcinogenesis paradigm "Epistemology of the origin of cancer" consisting of a six-step sequence: (1) a pathogenic stimulus followed by (2) chronic inflammation from which develops (3) fibrosis with associated remodeling of the cellular microenvironment; and from these changes a (4) precancerous niche $(\mathrm{PCN})$, a product of fibrosis, with remodeling by persistent inflammation, develops which triggers the deployment of (5) a chronic stress escape strategy and when this fails resolve it by (6) normal cell to cancerous cell transition (NCCCT) by PCN-induced cell matrix stress occurs. This figure was published in paper 3 of this Special Issue [29]. Nomenclature: The nomenclature common abbreviations are bold, followed by the common trivial names (if available) and (if available) by the name in accordance to the International Union of Pure and Applied Chemistry (IUPAC): PCN: precancerous niche; CSES: chronic stress escape strategy; NCCCT: normal cell to cancerous cell transition; SphK: sphingosine kinase isoform; S1P: sphingosine-1-phosphate; IL-6: interleukin 6; IL-8: interleukin 8; TNF $\alpha$ : tumor necrosis factor alpha; IFN $\gamma$ interferon gamma; ALOX: lipoxygenase, arachidonate lipoxygenase; ALOX12: 12-lipoxygenase, 12-LOX, 12S-LOX, arachidonate 12-lipoxygenase 12S type; ALOX5: 5-lipoxygenase, 5LOX, arachidonate 5-lipoxygenase; 12-HETE: 12-hydroxyeicosatetraenoic acid; LTA4: leukotriene A4, 4-[(2S,3S)-3-[(1E,3E,5Z, 8Z)-tetradeca-1,3,5,8-tetraenyl]oxiran-2-yl]butanoic acid; LTB4: leukotriene B4, (5S,6Z,8E,10E,12R,14Z)-5,12-dihydroxyicosa6,8,10,14-tetraenoic acid; LTC4: leukotriene C4, (5S,6R,7E,9E,11Z,14Z)-6-[(2R)-2-[[(4S)-4-amino-4-carboxybutanoyl]amino]-3(carboxymethylamino)-3-oxopropyl]sulfanyl-5-hydroxyicosa-7,9,11,14-tetraenoic acid; LTD4: leukotriene D4, (5S,6R,7E,9E, 11Z,14Z)-6-[(2R)-2-amino-3-(carboxymethylamino)-3-oxopropyl]sulfanyl-5-hydroxyicosa-7,9,11,14-tetraenoic acid; LTE4: leukotriene E4, (5S,6R,7E,9E,11Z,14Z)-6-[(2R)-2-amino-2-carboxyethyl]sulfanyl-5-hydroxyicosa-7,9,11,14-tetraenoic acid; 5-oxo-ETE: (6E,8Z,11Z,14Z)-5-oxoicosa-6,8,11,14-tetraenoic acid; Cox: cyclooxygenase; Cox-1: cyclooxygenase 1; Cox-2: cyclooxygenase 2; Cox-3: isoform of Cox-2 (therefore in brakes); PGG2: prostaglandin G2, (Z)-7-[(1S,4R,5R,6R)-5-[(E,3S)-3-hydroperoxyoct-1-enyl]-2, 3-dioxabicyclo[2.2.1]heptan-6-yl|hept-5-enoic acid; PGH2: prostaglandin H2, (Z)-7-[(1S,4R,5R,6R)-5-[(E,3S)-3-hydroxyoct-1-enyl]2,3-dioxabicyclo[2.2.1]heptan-6-yl]hept-5-enoic acid; PGFF2 $\alpha$ : prostaglandine F2 alpha, (Z)-7-[(1R,2R,3R,5S)-3,5-dihydroxy-2-[(E, 3S)-3-hydroxyoct-1-enyl]cyclopentyl]hept-5-enoic acid; PGD2: prostaglandin D2, (Z)-7-[(1R,2R,5S)-5-hydroxy-2-[(E,3S)-3-hydroxyoct-1-enyl]-3-oxocyclopentyl]hept-5-enoic acid; PGE2: prostaglandin E2, (Z)-7-[(1R,2R,3R)-3-hydroxy-2-[(E,3S)-3-hydroxyoct-1enyl]-5-oxocyclopentyl]hept-5-enoic acid; MDA: malondialdehyde, propanedial; TXA2: thromboxane A2, (Z)-7-[(1S,2S,3R,5S)-3[(E,3S)-3-hydroxyoct-1-enyl]-4,6-dioxabicyclo[3.1.1]heptan-2-yl]hept-5-enoic acid; CYP*: cytochrome P450 isoforms; 20-OHPGE2: 20-hydroxy prostaglandin E2; 20-HETE: 20-hydroxyeicosatetraenoic acid, (5Z,8Z,11Z,14Z)-20-hydroxyicosa-5,8,11,14tetraenoic acid; SOX: [sex-determining region Y (Sry) box-containing] transcription factor family; IL- $\beta$ 1: interleukin beta 1; IL-33: interleukin 33; ROS: reactive oxygen species; CXC CC: chemokine receptors; $\alpha$ SMAD: alpha-smooth muscle actin; miR21: micro RNA-21; p300: protein 300 (p300-CBP coactivator family); SP1: specificity protein 1; AP1: activator protein 1; E2F4/5: cytoplasmic complex of Smad3, retinoblastoma-like protein 1 (P107, RBL1), E2F4/5 and D-prostanoid (DP1); p107: retinoblastomalike protein 1, RBL1; TGF $\beta$ : transforming growth factor beta; Pro-MMP-9: pro-matrix metalloproteinase 9; Pro-MMP-1: promatrix metalloproteinase 1; Pro-MMP-7: pro matrix metalloproteinase 7; SNAIL: zinc finger protein SNAI1; MMP-1: matrix metalloproteinase 1; MMP-7: matrix metalloproteinase 7; MMP-2: matrix metalloproteinase 2; E-Cadherin: CAM 120/80 or epithelial cadherin, cadherin-1, epithelial cadherin; CXCL1: chemokine (C-X-C motif) ligand 1; Osm: oncostatin-M; PI3K: phosphatidylinositide 3-kinase; FOXO3a: forkhead box protein O3a; p120: catenin delta-1, protein 120; Rho: Ras homolog gene family, member A; Rac1: Ras-related C3 botulinum toxin substrate 1; cdc42: cell division control protein 42 homolog; BIM: Bcl-2 interacting mediator of cell death; PUMA: BH3-only protein; CXCR4: C-X-C motif of chemokine receptor 4; cdk2: cyclindependent kinase 2; LOXL3: lysyl oxidase homolog 3; mTORc1: rapamycin complex 1; PAI1: Plasminogen activator inhibitor-1. 
Wnt/ $\beta$-catenin activity is involved. Huh et al. found that increased nuclear p300 was associated with improved disease-free survival rates in colorectal cancer patients [203]. As pointed out correctly by Bordonaro and Lazaravo, "we would expect that cell lines derived from metastases would exhibit a greater degree of CBP-Wnt activity and less p300-Wnt activity compared to matched primary tumor samples from the same patient' [204].

miR21 downregulates the transformation suppressor Pdcd4 [187], and Pdcd4 usually inhibits the recruitment of the coactivator, p300, by c-Jun [186], suggesting that increased miR21 together with Pdcd4 suppression may be associated with increased p300.

\section{Specificity protein 1 (SP1) (Fig. 1)}

SP1 is a member of the SP transcription factor family containing "C2H2-type zinc fingers and resembles the larger family of 'Krüppel-like factors' ([205] reviewed in [206]) [Black J Cell Physiol 2001 reviewed in Beishline FEBS J 2015] and was first cloned in 1987 [207] [Kadonaga Cell 1987]. Zinc is necessary for nuclear translocation as well as for specific high-affinity binding ([208, 209] reviewed in [206]).

SP1 can have dual roles. For example, SP1 binding at the proximal and distal enhancer site activates transcription of the human topoisomerase IIa promoter "while competition between Sp1 and Sp3 for binding at either the distal enhancer or at both binding regions results in Sp3dependent repression" ([210] reviewed in [206]).

In cancer, elevated SP1 levels are associated with poor survival and tumor spread in glioma [211], thyroid [212], breast [213], lung [214] and gastrointestinal cancers such as gastric [215] and pancreatic cancer ([216] reviewed in [206]).

Fibroblast stimulation results in SP1 phosphorylation and is associated with increased transcription of SP1 [217]. SP1 stability at Ser586 regulates MMP-9 transcription secondary to Erk in alveolar macrophages [218]. Heptatits C virus (HCV)-induced increase of TGF- $\beta 1$ mediated by p38 MAPK, Src, JNK, and MEK1/2 also induces transcription factors $\mathrm{AP}-1, \mathrm{Sp} 1, \mathrm{NF}-\kappa \mathrm{B}$ and STAT-3 [219].

Angiotensin-II increases SP1 in a dose- and timedependent manner; microRNA-7a/b (miR-7a/b) effectively represses TGF- $\beta$, ERK, JNK and p38, and inhibits SP1mediated expression of MMP-2 and MMP-9, and activates fibroblast proliferation [220].

The important interplay between SP1 and chronic inflammation as a sequence in carcinogenesis is supported by the following examples: cytokine-driven PI3K/Akt/ Sp1 together with hydrogen sulphide $\left(\mathrm{H}_{2} \mathrm{~S}\right)$ impairs inflammation in an in vitro pancreatitis model [221]. SP1 binds to the promoter of the T-cell-specific T-box transcription factor (TBET) and enhances it in a dose-dependent manner, TBET and interferon gamma (IF $\gamma)$, in secretion in natural killer (NK) cells and $\mathrm{T}$ cells [222]; non-steroidal antiinflammatory drugs (NSAIDs) inhibited ERK activity with consequent lower SP1 phosphorylation and lower activation of MMP-2 [223].
Blocking the Sp1-TGF- $\beta 1 /$ Smad-connective tissue growth factor (CTGF) pathway by miRNA-29b in a rat model inhibited endometrial fibrosis [224]. Decreasing reactive oxygen species (ROS), cyclooxygenase 2 (Cox-2), collagen type II alpha 1 (Col 1A2), calcium, $\alpha$-SMA, Smad4-p-Smad2/3 co-localization in the cell nucleus, as well as DNA binding activity of SP1, in an early liver fibrosis model was achieved by a maleic acid derivative isolated from the Antrodia camphorata mycelium [225]. Knockdown of SP1 resulted in the abolishment of TGF- $\beta 1$ induced type I collagen production in renal fibrosis by miR-29c downregulation [226].

The Food and Drug Administration (FDA)-approved antihypertensive, Losartan, is an angiotensin II receptor type 1 inhibitor. Losartan (Los) suppresses fibrosis in cardiac muscle in mice [227], as well as inflammation and beta amyloid in rats [228]. Los decreases aszites in ovarian cancer [229], and experimental hepatocarcinogenesis and HCC development together with acyclic retinoid (ACR) [230] as well as tumor progression from DCIS to invasive cancer in breast cancer cell lines [231]. The Los effect appears to be associated through the suppression of THBS1 [232-234] with consecutive decrease of TGF- $\beta 1$, via decreases in the MAPK and NF- $\kappa$ B pathways in B and T cells [235] and induced antifibrotic miRNAs [229]. Furthermore, Los suppressed "cell proliferation in a dose-dependent manner, induced apoptosis, decreased YAP (Ser127), and downregulated the YAP target genes CTGF, CYR61, ANKRD1, and MFAP5" [236]. Los inhibit "intracellular angiotensinII production and AGTR2 nuclear localization to enhance the antitumoral effect of 5-FU in an OSCC tumor model' [237].

The intratumoral distribution and antitumor efficacy of nanoparticles are increased by Los [238]. Los increases paclitaxel efficacy and delivery for ovarian cancer [229], doubled progression free-survival in pancreatic cancer patients [239], reduced cancer-specific mortality in a population-based cohort study gastro-esophageal cancer between 1998 and 2012 from English cancer registries [240], and increased, retrospectively, overall survival by 30 months compared to standard therapy in ovarian cancer patients [229].

Treating pancreatic cancer xenografts with mithramycin (M) and tolfenamic acid (TA) resulted in Sp1 protein degradation and the combined treatment revealed fewer side effects compared to MIT or TA treatment alone [241]. Combining MIT with betulinic acid (BA) in a xenograft mouse pancreatic cancer model resulted in SP1 and VEGF promotion, transcription, and downregulation. This therapeutic regime resulted in fewer side effects compared to gemcitabine [242]. SP1 can function as TGF- $\beta$ mediated increased expression [243] and it has been reported to play a role in cell transition in gastric carcinoma cells which can be inhibited via miRNA-223 [244]. Dehydroandrographolide is an extract from the herbal medicine, Andrographis paniculata (Burm f), which upregulates tissue inhibitor of metalloproteinase-2 (TIMP-2) and downregulates NF- $\kappa \mathrm{B}, \mathrm{SP}-1$ and AP-1 expression with consequent MMP-2 inhibition suppressing cell transition, cancer cell migration and invasiveness [245]. 


\section{AP-1 (Fig. 1)}

AP-1 is composed of Jun (c-Jun, JunB, JunD) and Fos proteins (c-Fos, FosB, Fra-1, Fra-2) and is involved in inflammation, wound healing, and cancer [246]. Increased Fra-2 was shown to induce remodeling with chronic inflammation and fibrosis questioning the autoimmune cause of idiopathic pulmonary fibrosis (IPF). AP-1 can be induced by platelet-derived growth factor (PDGF) [247] or Bacteroides fragilis-induced enteritis together with Ras and MAPK signaling [248]. Furthermore, it can increase matrix metalloproteinase-7 (MMP-7, pump-1 protease, PUMP 1) [249]. AP-1 is also associated in HPV-induced cervical cancer [250] and radioresistance [251]. Increases in interleukin 13 (IL-13) by AP-1 induces TGF- $\beta 1$, triggering fibrosis in the bleomycin model [252].

Salvia miltiorrhiza extracts, used in traditional Chinese medicine for gynecological diseases, have an anti-inflammatory effect [253] and inhibit AP-1 suppressing 12-O-tetradecanoylphorbol-13-acetate (TPA)-treated MCF-7 cells and MMP-9 expression [254]. Otherwise, AP-1 and mitogenactivated protein kinase (MAPK) was shown to increase MMP-9 expression in fibroblasts [255]. The PI3K and MAPK paths are involved in MMP-9 increase and are also regulated by $\mathrm{AP}-1, \mathrm{NF}-\kappa \mathrm{B}$ or SP1. Blocking ERK/AP-1 and protein kinase $\mathrm{C}(\mathrm{PKC})$ extracellular signaling by $3,5,7,3^{\prime}, 4^{\prime}$-pentahydroxylflavone (QUE, Quercetin) suppresses MMP-9 in breast cancer cells [256].

TGF- $\beta 1$ increases AP-1 through CD44V6/ERK1/early growth response protein 1 (EGR1) signaling [257] and miR21 expression was shown to be increased in the Jun/AP-1 psoriasis-like mouse model [258]. The miR21 promoter region provides binding sites for AP-1 [259]. miR21 inhibits Pdcd4 and upregulation of miR21 "is mediated by AP-1 components c-Jun and c-Fos in SP cells" [260]. AP-1 inhibition by 2,3,7,8-tetrachlorodibenzo-p-dioxin (TCDD) is dependent from AHR [261].

\section{Aryl hydrocarbon receptor (AHR)}

AHR is a cytosolic transcription factor with pro- and anti-inflammatory activity and serves as a central modulating receptor of inflammatory response [262]. AhR was discovered as a specific binding site to TCDD [263], inducing aryl hydrocarbon hydroxylase [264], with proven AHR induction by TCDD [265]. Later, it was proven that cytosolic AHR translocates temperature-dependent into the nucleus which is necessary to induce cytochrome P450 $[266,267]$ and that aryl hydrocarbon receptor nuclear translocator (ARNT) is an essential dimerization partner for the AHR [268].

AHR is usually inactive and a higher expression is associated with breast cancer [269-272]. AHR is thought to directly increase c-myc mRNA and c-Myc protein [273] which may explain why c-myc expression is also increased in breast cancers [274-278] as well as in various other cancers, such as leukemia, lymphoma, plasmocytoma [279-281], lung cancer [282, 283], neuroblastoma [284], liver cancer [285, 286], testicular cancer [287], or colorectal cancer [288, 289].

Constitutive NF- $\kappa \mathrm{B}$ activation is increased in both breast cancer tissues and cell lines [290] and there is a direct association between the NF- $\kappa \mathrm{B}$ subunit RelA and AHR in murine hepatoma cells [291]. Kim et al. showed in malignant and non-malignant breast cell lines, that RelA and AHR but not NF- $\kappa$ B RelB or c-Rel subunits build a transcription factor complex resulting in c-myc gene expression [292]. "The pleiotropic interleukin (IL)-6-type cytokine oncostatin M (OSM) is an inducer of AHR mRNA and protein expression in human HepG2 hepatocarcinoma cells" [293] and AHR-dependent IL-6 expression which is associated with IL- $\beta 1$-induced binding of NF- $\kappa \mathrm{B}$ components [294]. AHR-inhibition, but not cytochrome P450, family 1 , subfamily A, polypeptide 1 (CYP1A1) inhibition, induces transcription factor p65 encoded by RELA gene (RelA), transcription factor encoded by the RELB gene interacting with $\mathrm{NF}-\kappa \mathrm{B}$ (RelB), nuclear factor kappalight-chain-enhancer of activated B cells 1 (NF- $\kappa \mathrm{B} 1$ ), nuclear factor kappa-light-chain-enhancer of activated $\mathrm{B}$ cells 2 (NF- $\kappa$ B2) and MMP-1 promoting cancer invasiveness. Additionally, there is a different mechanism affecting 12-hydroxyeicosatetraenoic acid (12-HETE). Inhibiting $\mathrm{NF}-\kappa \mathrm{B} 2$ is associated with induced AHR, CYP1A1 and 12 -HETE synthesis and both CYP1A1 and NF- $\kappa \mathrm{B}$ can be inhibited in vitro by the alpha-2A adrenergic receptor $\left(\alpha_{2 \mathrm{~A}}\right.$ receptor $)$ agonist guanfacine and ethyl apovincaminate (vinpocetine) [295].

AHR deletion was associated with "failure to control Citrobacter rodentium infection due to unrestricted intestinal stem cell (ISC) proliferation and impaired differentiation, culminating in malignant transformation" [296].

AHR deficiency is enhanced by chronic inflammation in colon carcinogenesis. Otherwise, AHR activation by AHR dietary ligands such as dietary components and tryptophan metabolites regulated intestinal crypt stem cell differentiation and was associated with prevention of carcinogenesis in mice through really interesting new gene (ring) finger protein 43 (Rnf43) and the cell-surface transmembrane E3 ubiquitin ligase zinc and ring finger 3 (Znrf3, homologue of Rnf43), E3 ubiquitin ligases with inhibition of Wnt$\beta$-catenin signaling and consequent decrease of ISC proliferation. This may underpin the integrity role of AHR acting as a host defense [297].

Applying the potent AHR ligand, TCDD, in lymphoma cells (U937) increased " $m R N A$ levels of cyclooxygenase-2, interleukin 1beta, and tumor necrosis factor-alpha" in a dose-dependent manner with enhanced MMP-1, matrix metalloproteinase 3 (MMP-3, stromelysin-1), matrix metalloproteinase 12 (MMP-12, macrophage metalloelastase, $\mathrm{MME}$ ), and matrix metalloproteinase 13 (MMP-13, collagenase 3) and TCDD stimulated macrophage cell migration and promoted its differentiation into atherosclerotic plaque-forming foam cells [298].

Therapy with the AHR agonist TCDD in mice induced fibrosis markers (collagen 1A1 and $\alpha$-smooth muscle actin), with increased interleukin-1 beta, tumor necrosis factor $\alpha$ and fibroblast activating fibroblast-specific protein 1 
(FSP1, S100A4) together with an increase of TGF- $\beta$ and Snail with an decrease of E-Cadherin and Claudin 1. The fibrosis was histologically apparent after 6 weeks [299]. As AHR knockout rats are insensitive to repeated TCDD exposure, AHR seems to be a regulator of fibrosis and carcinogenesis following TCDD treatment [300]. TCDD treatment at first increased rodent hepatic stem cells (rHpSCs) followed by a loss of loss of viability of hepatoblasts (rHBs) [301]. TCDD promotes cell transition through AHR-mediated EGFR/ERK signaling [302].

A catabolite of tryptophan, kynurenine (Kyn), was shown to be excessively produced by glioma cells through tryptophan-2,3-dioxygenase (TDO) with consequent binding and activation of AHR [303]. AHR was found to downregulate TGF- $\beta$ signaling in non-neoplastic astrocytes and "constitutive AHR activity positively controls TGF- $\beta 1$, TGF- $\beta 2$ and latent TGF- $\beta$-binding protein-1 protein levels in malignant glioma cells" and AHR inhibition resulted in lower survival and invasiveness of glioma cells [304].

Although indoleamine-2,3-dioxygenase 1 (IDO1) and IDO2 are expressed in human cancers it was shown, that levo- but not dextro-1-methyl tryptophan (D-1MT) inhibits tryptophan catabolism [305]. Otherwise D-1MT reduces tumor $\mathrm{CD} 133+$ cells, Wnt $/ \beta$-catenin and $\mathrm{NF}-\kappa \beta \mathrm{p} 65$ and decreases TGF- $\beta$, IDO, chemokine $(\mathrm{C}-\mathrm{C}$ motif) ligand 5 (CCL5, RANTES), and programmed death-ligand 1 (PDL1) in murine pancreatic adenocarcinoma [306]. The selective IDO inhibitor and synthetic analog of tryptophan, 1methyl tryptophan (1MT) increases in vitro the AHR nucleo-translocation and response in mesenchymal stromal cells [307]. AHR is associated with MMP-1 [308], MMP-9 increase [309-311]. The carcinogen, benzo[a|pyrene, triggers MMP-9 together with c-myc expression which is mediated through AHR and ERK signaling [312] and decreasing AHR inhibits gastric cancer cell growth and invasiveness [313].

Heat-shock protein 90 (Hsp90), binds to cytoplasmatic AHR and chaperones with nucleus translocation and dimerization of AHR with ARNT and dissociation of chaperone proteins. The xenobiotic responsive element (XRE, AAH response element, AHRE) [314] binds to AHR with induction of cytochrome isoform (CYP*) [315] such as CYP1A1, CYP1A2, CYP1B1, CYP2S1 and glutathione-S-transferase (GST) and uridine glucuronosyltransferases (UGT) ([316] reviewed in [317]). Benzo[a]pyrene $(\mathrm{B}[\mathrm{a}] \mathrm{P})$ is an inducer of CYP1A1 while AHR is present; topical $\mathrm{B}[\mathrm{a} \mid \mathrm{P}$ application only induces skin cancer in AHR positive mice [318] using AHR-mediated enzyme induction as an anti-cancer strategy $[317,319]$.

In terms of the proposed sequences of carcinogenesis [22, $31,320]$, dioxin induces leukotriene B4, $(5 \mathrm{~S}, 6 \mathrm{Z}, 8 \mathrm{E}, 10 \mathrm{E}$, 12R,14Z)-5,12-dihydroxyicosa-6,8,10,14-tetraenoic acid, LTB4) through AHR [321] and AHR mediates fibroblast migration through upregulated arachidonic acid metabolism [322]. Hexachlorobenzene (HCB) induces chronic inflammation increasing MMP-9 via c-Src kinase with disruption of eicosanoid homeostasis by upregulation of Cox-2, prostaglandin E2 (Z)-7-[(1R,2R,3R)-3-hydroxy-2[(E,3S)-3-hydroxyoct-1-enyl]-5-oxocyclopentyl]hept-5-enoic acid, PGE2) and omega-3 fatty acids eicosapentaenoic acid (EPA) receptor with implication of AHR and induction of endometriosis in vitro [323]. Using rat liver and humanderived hepatoma cell line, HepG2, it was shown that HCB induces an increase of AHR expression, cell proliferation and "cyclin D1 protein levels and ERK1/2 phosphorylation in a dose-dependent manner" which is mediated by AHR promoting liver carcinogenesis [324].

Recently AHR was reported to act as a repressor of inflammation associated in colon cancer [325]. These contradictory dictionary findings can be explained as was clearly shown that the concentration on one variable will not be enough to understand complexity and that AHR is involved in carcinogenesis but CYP isoforms will not be expressed in AHR knockdown mice $\operatorname{AhR}(-/-)$ mouse and that CYP1A1 is needed [318]. This reveals how just looking at findings in one knockout mouse model without simultaneously taking into account coactivator and/or associated other necessary variables and mediators will result in complete contradictionary findings and interpretations. Moreover, AHR negatively cross-talks with NF- $\kappa \mathrm{B}$ but not with CYP1A1 [295]. The AHR ligand 6-formylindolo (3,2-b) carbazole (Ficz) is an AHR agonist in zebrafish inducing various CYP* such as CYP1A1, CYP1B1 [326] which explains why Ficz is protective against AHRmediated chronic inflammation and downregulates interleukin 7 (IL-7) and dextran sulfate sodium (DSS)-induced colitis in wild-type C57BL/6J mice [327]. We assume that assessing AHR can only be accomplished by taking into account the eicosanoid pathway and its cytochrome P450 pathway, including its many isoforms which has been reviewed in this Special Issue [30].

AHR-mediated carcinogenesis with the disruption of eicosanoid homeostasis as reviewed recently [30], is involved in breast cancer [328, 329], colitis associated colon cancer through miR-132 expression after AHR activation by TCDD [330].

$\mathrm{B}[\mathrm{a}] \mathrm{P}$ induces AHR-dependent IL-10 increase with chronic inflammation [331] and AHR is involved in inflammatory fibrosis of the pancreas [332] and the liver [333]. It depends whether or not AHR is already translocated from its inactive cytoplasmic form to the nucleus.

L-kynurenine ((S)-2-Amino-4-(2-aminophenyl)- 4-oxobutanoic acid) is a metabolite of the amino acid L-tryptophan through tryptophan dioxygenase in the liver and indoleamine 2,3-dioxygenase (IDO) by various human cells; IDO derived Kyn is an endogenous ligand of the human AHR, which is increased in chronic inflammation, promoting cancer cell survival and metastasis in brain cancer cells [303]. The D-enantiomer of kynurenine, D-kynurenine (D-Kyn), is increased in lung cancer cells and is associated with increased vimentin and increases in CYP1A1 and AHR nuclear translocation promoting cell transition [334]. Inactivating the dioxin-like polychlorinated biphenyl (PCB), PCB126, stimulates upregulation of ROS through AHR. Promoting cell transition is in this instance regulated through signal transducer and activator of transcription 3 (STAT3)/Snail1 which is dependent on pyruvate kinase M2 (PKM2) [335]. High expression of its 
members IDO, STAT3 and the AHR target gene CYP1B1 is associated with reduced relapse-free survival in lung cancer patients [336]. GSK-3 $\beta$ suppresses ESCC growth via STAT3 [337] but it seems that AHR is involved as well. Inactivating GSK-3 $\beta$ by the aminopyrimidine derivative CHIR-99021 reverses vimentin degradation in AHR overexpressed H1299 cells but it depends where AHR is increased/ activated. Cytoplasmatic (inactive) AHR suppresses cell transition via augmentation of mesenchymal vimentin level, and GSK-3 $\beta$ Ser-9 hyper-phosphorylation [338].

The AHR-TGF- $\beta 1$ crosstalk is also complex. AHR can downregulate TGF- $\beta 1$ signaling through latent transforming growth factor-beta binding protein 1 (LTBP-1) [339] or result in a deregulation of TGF- $\beta 1$ secretion [340], but there is an association between AHR, TGF- $\beta 1$ and the repetitive DNA sequence long interspersed nuclear element-1 (LINE1) which sheds a new light on carcinogenesis and cancer associated findings.

\section{Long interspersed nuclear element-1 (LINE1)}

Human transposable elements include RNA and DNA families, and RNA transposons (retrotransposons, retroelements) are divided into long-terminal repeat (LTR) LTR)containing or non-LTR groups and "The active, human non-LTR group includes LINE-1 (or L1), next to short interspersed elements (SINE) represented by Alu, and the more recently characterized SVA elements" and estimated some $45 \%$ of the human genome originates from transposable elements [341, 342]. LINE1 "retrotransposons make up a significant portion of human genomes, with an estimated 500000 copies per genome" [343].

LINE-1 is regulated and repressed in human tissue by DNA methylation [344-347] and "long-term NSAID use and a normal BMI were associated with increased LINE-1 DNA methylation" as well as a healthy life-style [348, 349]. Chronic inflammation, oxidative stress, and environmental changes can induce and restore LINE-1 methylation [350-353] but not in gingival inflamed tissues [354]. LINE-1 is reactivated by the AHR agonist $(\mathrm{B}[\mathrm{a}] \mathrm{P})$ through TGF- $\beta 1$ signaling in human liver cancer samples "at various stages of malignant progression" [355].

The association of chronic inflammatory, environmental, oxidative stress and external pathogenic stimuli induced somatic LINE-1 restoration without the need of any mutations together with $\mathrm{AHR}$ and $\mathrm{CYP}^{*}$ findings should cast a new light in the observed LINE-1 transpositions observed in various diseases and cancers.

LINE-1 demethylation and restoration (reviewed in [341, 342, 344]) is associated with neuronal development [356, 357], inflammatory diseases [358], colitis [359], disruption of the adenomatous polyposis coli (APC) gene [360], colorectal cancer [361, 362], breast cancer [363-365] or liver cancer [366].

"Factors belonging to the family of the testis-determining factor gene SRY (the SOX family)" regulate LINE-1 [367] and Dicer, which is downregulated by $\beta$-catenin and decreased in aggressive cancers [167], and which negatively regulates LINE-1 [368]. A LINE1 transcript "driven by an $H B x$ promoter, referred to as HBx-LINE-1" activates $\mathrm{Wnt} / \beta$-catenin signaling, promotes cell transition, and is expressed in HCC in mice and associated with poor survival and HBx-LINE-1 [369]. LINE1 inhibition results in altered cell morphology [370, 371] and reversed cell transition (Fig. 2 from [372] not shown).

LINE1 hypermethylation as well as transcription factor SOX-11 (SOX11) and insulin-like growth factor 2 (IGF2), solute carrier family 22 (organic anion/cation transporter), member 12 (SLC16A12), P2X purinoceptor 7 (P2RX7) and myogenic differentiation 1 (MYOD1) were associated with H. pylori infection status and atrophic gastritis, which are precancerous conditions of gastric cancer [373]. LINE1 and IGF2 methylation in the leukocyte DNA hypermethylation was associated with more aggressive gastric cancer and progression [374].

\section{Chronic cell matrix stress Activin A receptor like type (ALK)}

p120 selectively inhibits the small GTPase Ras homolog gene family, member A (RhoA) activity both in vitro and in vivo [375]. TGF- $\beta 1$ induces cell transition via increased RhoA activity [376] which is dependent on activin receptor-like kinase 5 (ALK5) [377].

The transmembrane serine/threonine receptor kinase, activin A receptor like type 1 (ALK1), functions as an alternative type I receptor for TGF- $\beta$ and increases in ALK1 occur due to elevated MMP-13. The interaction between ALK1 and the TGF- $\beta$ type I receptor activin-like kinase 5 (T $\beta$ RI or ALK5) with its ALK1/ALK5 ratio is age-related with a shift to decreased ALK5 in aged mice [378]. ALK1 signaling via MMP-13 results in type II collagen degradation. In young animals, ALK5 is protective of collagen degradation but during aging the ALK1/ALK5 ratio changes as does the role of TGF- $\beta$. This maybe relevant as ALK1 is involved in angiogenesis [379] and lends credence to why anti-ALKL1 therapy may be useful in certain cancer therapies [380].

\section{Protein 120 (p120, catenin delta-1)}

The shift in localization of protein 120 (p120, catenin delta-1) was associated with a decrease in RhoA activation, and E-cadherin loss which resulted in decreased mobility of cells [381]. In p53-deficient mice, the tumor suppressor p120 "is dominant over E-cadherin inactivation and its inactivation promotes the development of basal, EMT-type invasive mammary tumors" [382]. Due to an increase of TGF- $\beta$ [383, 384] and a decrease in E-Cadherin, the long isoform of p120 dissociates from the membrane and accumulates within the cytoplasm [385]. The p120 family shows redundancy including delta catenin $(\delta$-catenin, cadherin-associated protein 2 , CTNND2, neural plakophilin-related arm-repeat protein, NPRAP), armadillo repeat protein deleted in velo-cardiofacial syndrome (ARVCF), armadillo protein p0071 (plakophili4), the more distantly related plakophilins $1-3$, which 
regulate cadherins important for cell-cell communication and for adhesion [386].

The RhoGTPase family consists of, among others, RhoA, cell division control protein 42 homolog (Cdc42), and Ras-related C3 botulinum toxin substrate 1 (Rac1) [387]. The chemokine growth-regulated purported oncogene 1 (Gro-1) [388] binds to C-X-C motif chemokine receptor 2 (CXCR2, Interleukin 8 receptor, beta, IL8RB) receptors [389], is activated by the small GTP-binding protein RAS, and induces senescence of fibroblasts with consequent stromal reprogramming facilitating carcinogenesis, which is why it is considered a potential target in cancer therapy [390].

Ras is activated by epidermal growth factor (EGF) with consequent RAS movement from an inactive GDP-bound state to an active GTP-bound state [391]. p120 can increase Cdc42 and Rac without altering Rho activity [392]. It is considered that the localization of p120 affects cell motility. p120 activates Rac1/MAPK signaling in breast cancer cells [393] but p120 can also be regulated depending on cancer cell type and through inactivation of E-cadherin [394].

Increased cytoplasmic p120 levels were observed in invasive gastric cancer [395] and loss, or even p120 translocation into the cytoplasm, was associated with cancer and with disease progression [394]. H. pylori induced MMP-7 expression is regulated by p120 and Kaiso [396], which is "a novel member of the rapidly growing BTB/POZ (Broad complex, Tramtrak, Bric à brac/Pox virus and zinc finger) family of zinc finger $(Z F)$ transcription factors (hereafter referred to as POZ-ZF proteins" [397]. The interaction between p120, Rho and cadherins is complex [398], as Rho increases, Rac activity increases through loss of p120 [399].

ECM remodeling through Rac and Cdc42 activation was shown in rat fibroblasts [400]. Silencing of the Rac1 gene results in increased degradation of the ECM, suggesting that Rac1 inhibitors might play an important role in cancer therapy [401]. Rac1 silencing in lung cancer cells was also associated with inhibition of NF- $\kappa \mathrm{B}$ with a corresponding decrease in cell proliferation [402].

The ROS-mediated Src activation also increases tyrosine phosphorylation of p120-catenin with consequent p120 translocation [403]. As mentioned earlier, the p120 translocation and cytoplasmatic accumulation due to continuous TGF- $\beta$ and LOX activation influence ECM remodeling and "this process may be seen as the starting point for the chronic-stress escape strategy as proposed' [22, 31].

\section{Summary}

In nature, cells routinely undergo both de-differentiation and re-differentiation. The transition of one cell type to another, including its transition from one cell function to another is incompletely understood mechanistically. Science has learned from embryogenesis and morphogenesis that this biological process is routine and not an exception. The normal cell to cancer cell transition occurs when the necessary groundwork has been prepared by sequences that include pathogenic stimuli, chronic inflammation, remodeled fibrosis (PCN) and a failed chronic stress escape strategy (CSES) that results in a disruption of homeostasis essentially creating an imbalance of pro- and contra- cell transition conditions (Fig. 1). The multiplicity of pathways and signaling events that a cell, tissue, or organism can enlist to prevent or abort the transition from a normal to a cancer cell in a sequenced process that describes carcinogenesis does not need the invocation of somatic mutations. Many of the pathways and signaling mechanisms described involve biochemical processes that are a routine part of a dynamic homeostasis involved in growth and development. Thus, an overview of these complex inter-connected "Disruption of signaling homeostasis induced crosstalk in the carcinogenesis paradigm Epistemology of the origin of cancer" plays a key role in the development of cancer although current understanding does not permit a weightof-evidence risk assessment on the importance of any given signaling pathway or biochemical mechanism. Despite that limitation, the data strongly support crucial roles for inflammation and fibrosis via a PCN-sequenced event that comprises carcinogenesis.

\section{Nomenclature of abbreviations}

1MT 1-methyl tryptophan

5-oxo-ETE (6E,8Z,11Z,14Z)-5-oxoicosa-6,8,11, 14-tetraenoic acid

12-HETE 12-hydroxyeicosatetraenoic acid

20-HETE 20-hydroxyeicosatetraenoic acid, (5Z,8Z,11Z,14Z)-20-hydroxyicosa$5,8,11,14$-tetraenoic acid

20-OH-PGE2 20-hydroxy prostaglandin E2

$\alpha_{2 \mathrm{~A}}$ receptor Alpha-2A adrenergic receptor

$\alpha$ SMAD Alpha-smooth muscle actin

$\beta$-catenin $\quad$ Catenin beta- 1

$\delta$-catenin Delta catenin, cadherin-associated protein 2, CTNND2, neural plakophilin-related arm-repeat protein, NPRAP),

\section{ACR Acyclic retinoid}

AHR

Akt

ALK

ALK5

ALOX

ALOX12

Aryl hydrocarbon receptor

Protein kinase B

Activin A receptor like type

Activin receptor-like kinase 5

Lipoxygenase, arachidonate lipoxygenase 12-lipoxygenase, 12-LOX, 12S-LOX, arachidonate 12-lipoxygenase $12 \mathrm{~S}$ type

ALOX5 5-lipoxygenase, 5-LOX, arachidonate 5 -lipoxygenase

AP-1 Activator protein 1

ARNT Aryl hydrocarbon receptor nuclear translocator

ARVCF Armadillo repeat protein deleted in velo-cardio-facial syndrome

B[a]P Benzo[a]pyrene

BA Betulinic acid 


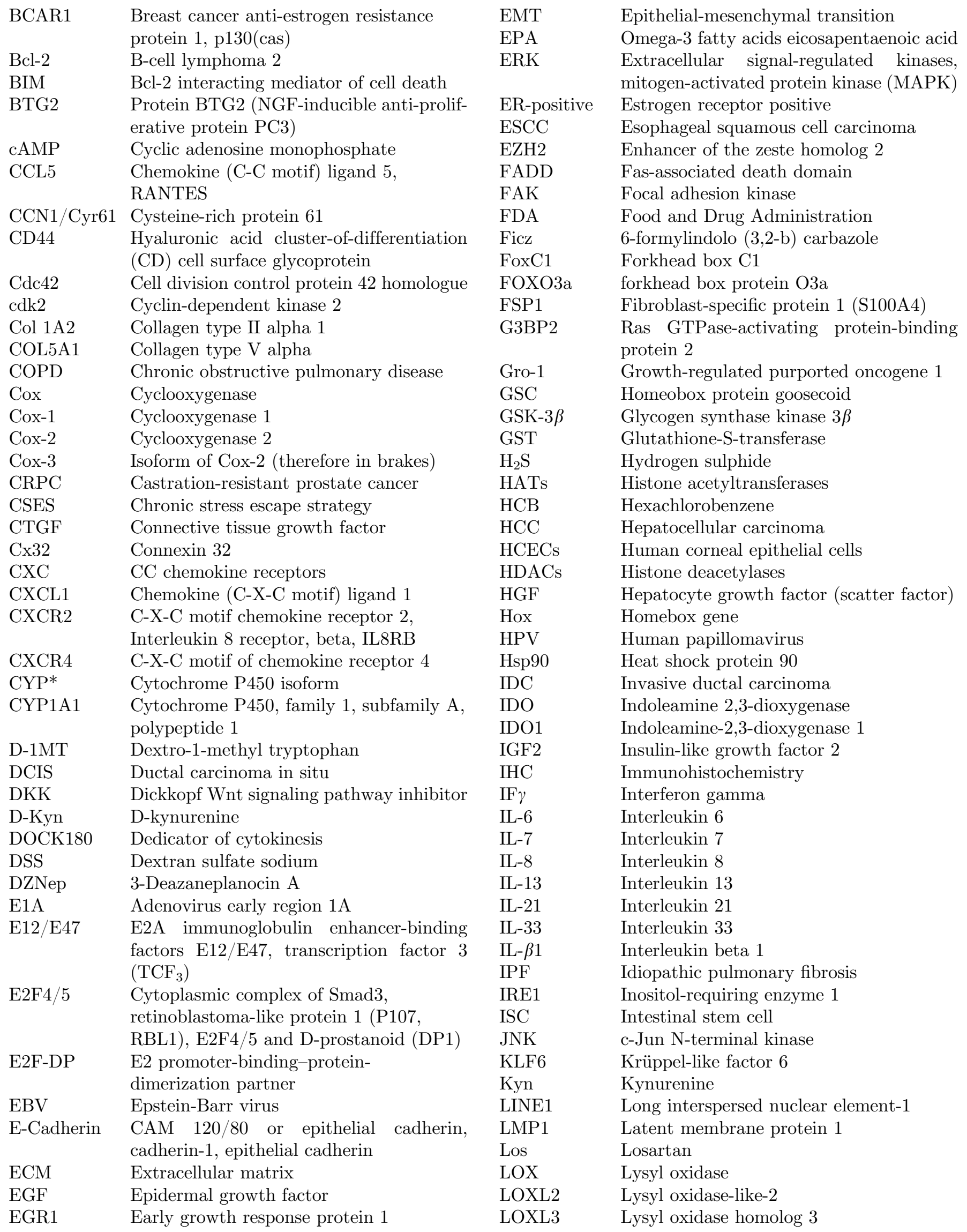




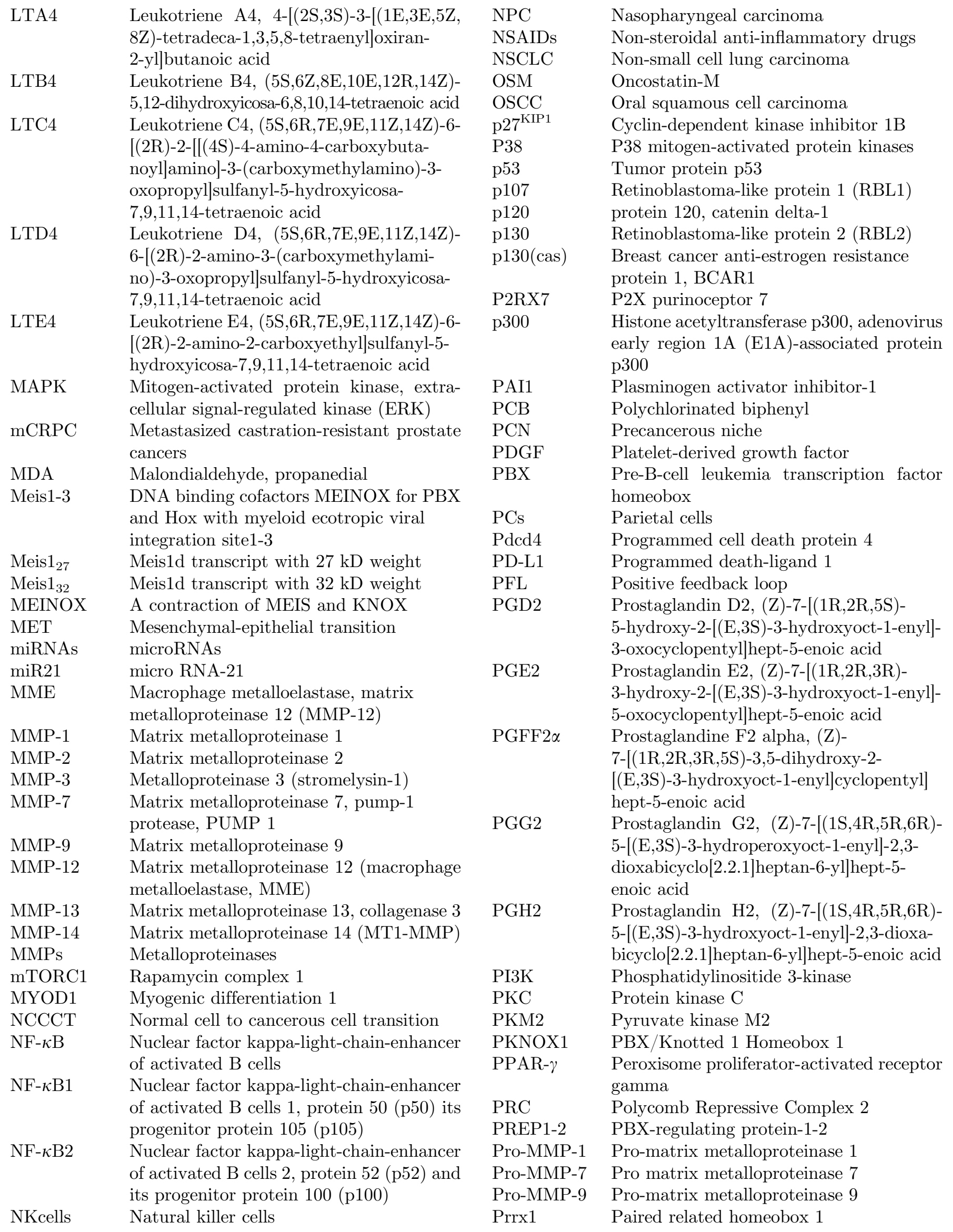


PSCs

PTEN

PTTG1

PUMA

PUMP1

QUE

Rac1

RANTES

$\mathrm{RB}$

RB1

RB2

RB1CC1

RBL1

RBL2

RelA

RelB

rHBs

RhoA

Rnf43

ROS

S1P

SIP1

Sine

SLC16A12

SLK

Slug

SNAI1

SNAI2

Snail

SOX

SOX11

SP1

SphK

Src

SPRY1

SPRY2

Sry

Syk

STAT3

TALE

TBET

TCDD

$\mathrm{TCF}_{3}$
Pancreatic stellate cells

Phosphatase and tensin homolog

Pituitary tumor transforming gene 1

BH3-only protein

Pump-1 protease, matrix

metalloproteinase 7, MMP-7

$3,5,7,3^{\prime}, 4^{\prime}$-pentahydroxylflavone,

Quercetin

Ras-related C3 botulinum toxin substrate

1

Chemokine (C-C motif) ligand 5, CCL5

Retinoblastoma

Retinoblastoma protein 1

Retinoblastoma protein 2

Retinoblastoma coiled coil protein 1

Retinoblastoma-like protein 1 (p107)

Retinoblastoma-like protein 2 (p130)

Transcription factor p65 encoded by

RELA gene,

Transcription factor encoded by the

RELB gene interacting with NF- $\kappa \mathrm{B}$

Hepatoblasts

Ras homolog gene family, member A

Really interesting new gene (ring) finger

protein 43

Reactive oxygen species

Sphingosine-1-phosphate

Survival of motor neuron protein-

interacting protein 1

Short interspersed elements

Solute carrier family 22 (organic anion/

cation transporter), member 12

STE20-like serine/threonine-protein

kinase

Zinc finger protein SNAI2

Zinc finger protein SNAI1 (Snail)

Zinc finger protein SNAI2 (Slug)

Zinc finger protein SNAI1

Sry-related high-mobility-group Box

Transcription factor SOX-11

Specificity protein 1

Sphingosine kinase isoform

Proto-oncogene tyrosine-protein kinase

Protein sprouty homolog 1

Protein sprouty homolog 2

Sex-determining region $\mathrm{Y}$

Spleen tyrosine kinase

Signal transducer and activator of transcription 3

Three-amino acid extension loop protein

T-box transcription factor

2,3,7,8-tetrachlorodibenzo-p-dioxin

Transcription factor 3, E2A immunoglobulin enhancer-binding factors E12/E47
TDO

TGF- $\beta 1$

THBS1

TIMPs

TIMP-1

TIMP-2

TNC

$\mathrm{TNF} \alpha$

TNFR1

TPA

TRADD

Twist1

TXA2

UGT

VEGF

WNT5A

XBP1

XRE

ZEB1

ZEB2

Znrf3

\section{Acknowledgments}

The manuscripts of this Special Issue were supported by the Theodor-Billroth-Academy ${ }^{\circledR} \quad\left(\mathrm{TBA}^{\circledR}\right)$ and INCORE, (International Consortium of Research Excellence) of the $\left(\mathrm{TBA}^{\circledR}\right)$. We express our gratitude to the discussions on the web group of the Theodor-BillrothAcademy ${ }^{\circledR}\left(\mathrm{TBA}^{\circledR}\right)$ on LinkedIn, the exchange with scientists at Researchgate.com, as well as personal exchanges with distinguished colleagues who stimulated our thinking all named individually earlier in publications - we thank each one.

\section{Conflict of Interest}

The author reports the following conflict of interest: Björn LDM Brücher is Editor-in-Chief in Life SciencesMedicine of 4open by EDP Sciences. Ijaz S. Jamall is Senior Editorial Board member in Life Sciences-Medicine of 4open by EDP Sciences. The authors, of their own initiative, suggested to the Managing Editorial to perform a transparent peer-review of their submittals. Neither author took any action to influence the standard submission and peer-review process, and report no conflict of interest. The authors alone are responsible for the content and writing of the manuscript of this Special Issue. This manuscript contains origi- 
nal material that has not previously been published. Both authors contributed to the discussion on its contents and approved the manuscript.

\section{References}

1. Brocklehurst JR, Freedman RB, Hancock DJ, Radda GK (1970), Membrane studies with polarity-dependent and excimer-forming fluorescent probes. Biochem J 116, 4, 721-731. PMCID: PMC1185418.

2. Euteneuer U, Jackson WT, McIntosh JR (1982), Polarity of spindle microtubules in Haemanthus endosperm. J Cell Biol 94, 3, 644-653. PMCID: PMC2112214.

3. Svetina S, Zeks B (1990), The mechanical behaviour of cell membranes as a possible physical origin of cell polarity. J Theor Biol 146, 1, 115-122. PMID: 2232827.

4. Montesano R, Schaller G, Orci L (1991), Induction of epithelial tubular morphogenesis in vitro by fibroblastderived soluble factors. Cell 66, 4, 697-711.

5. Montesano R, Matsumoto K, Nakamura T, Orci L (1991), Identification of a fibroblast-derived epithelial morphogen as hepatocyte growth factor. Cell 67, 5, 901-908. PMID: 1835669 .

6. Graf von Stosch A, Kinzel V, Reed J (1996), Extension of the polarity-dependent "switch phenomenon" of the gp120 binding domain as a target for antiviral chemotherapy. Biochemistry 35, 2, 411-417. https://doi.org/10.1021/ bi952045w.

7. O'Brien LE, Jou TS, Pollack AL, Zhang Q, Hansen SH, Yurchenco P, Mostov KE (2001), Rac1 orientates epithelial apical polarity through effects on basolateral laminin assembly. Nat Cell Biol 3, 9, 831-838. https://doi.org/ 10.1038/ncb0901-831.

8. O'Brien LE, Zegers MM, Mostov KE (2002), Opinion: Building epithelial architecture: Insights from threedimensional culture models. Nat Rev Mol Cell Biol 3, 7, 531-537. https://doi.org/10.1038/nrm859.

9. Wedlich-Soldner R, Wai SC, Schmidt T, Li R (2004), Robust cell polarity is a dynamic state established by coupling transport and GTPase signaling. J Cell Biol 166, 6, 889-900. https://doi.org/10.1083/jcb.200405061.

10. Cui C, Chatterjee B, Lozito TP, Zhang Z, Francis RJ, Yagi H, Swanhart LM, Sanker S, Francis D, Yu Q, San Agustin JT, Puligilla C, Chatterjee T, Tansey T, Liu X, Kelley MW, Spiliotis ET, Kwiatkowski AV, Tuan R, Pazour GJ, Hukriede NA, Lo CW (2013), Wdpcp, a PCP protein required for ciliogenesis, regulates directional cell migration and cell polarity by direct modulation of the actin cytoskeleton. PLoS Biol 11, 11, e1001720. https://doi.org/ 10.1371/journal.pbio.1001720.

11. Roignot J, Peng X, Mostov K (2013), Polarity in mammalian epithelial morphogenesis. Cold Spring Harb Perspect Biol 5, 2, a013789. https://doi.org/10.1101/cshperspect. a013789.

12. Burute M, Prioux M, Blin G, Truchet S, Letort G, Tseng Q, Bessy T, Lowell S, Young J, Filhol O, Théry M (2017), Polarity reversal by centrosome repositioning primes cell scattering during epithelial-to-mesenchymal transition. Dev Cell 40, 2, 168-184. https://dpo.org/10.1016/j. devcel.2016.12.004.

13. Yu W, O'Brien LE, Wang F, Bourne H, Mostov KE, Zegers MM (2004), Hepatocyte growth factor switches orientation of polarity and mode of movement during morphogenesis of multicellular epithelial structures. Mol Biol Cell 14, 2, 748-763. https://doi.org/10.1091/mbc.e02-06-0350.
14. Liang J, Balachandra S, Ngo S, O’Brien LE (2017), Feedback regulation of steady-state epithelial turnover and organ size. Nature 548, 7669, 588-591. https://doi.org/10.1038/ nature23678.

15. Hartwell KA, Muir B, Reinhardt F, Carpenter AE, Sgroi DC, Weinberg RA (2006), The Spemann organizer gene, Goosecoid, promotes tumor metastasis. Proc Natl Acad Sci USA 103, 50, 18969-18974. https://doi.org/10.1073/ pnas.0608636103.

16. Peinado H, Olmeda D, Cano A (2007), Snail, Zeb and bHLH factors in tumour progression: An alliance against the epithelial phenotype? Nat Rev Cancer 7, 6, 415-428. https://doi.org/10.1038/nrc2131.

17. Ouyang G, Wang Z, Fang X, Liu J, Yang CJ (2010), Molecular signaling of the epithelial to mesenchymal transition in generating and maintaining cancer stem cells. Cell Mol Life Sci 67, 15, 2605-2618. https://doi.org/10.1007/ s00018-010-0338-2.

18. Gregory PA, Bracken CP, Smith E, Bert AG, Wright JA, Roslan S, Morris M, Wyatt L, Farshid G, Lim YY, Lindeman GJ, Shannon MF, Drew PA, Khew-Goodall Y, Goodall GJ (2011), An autocrine TGF-beta/ZEB/miR-200 signaling network regulates establishment and maintenance of epithelial-mesenchymal transition. Mol Biol Cell 22, 10, 1686-1698. https://doi.org/10.1091/mbc.E11-02-0103.

19. Liu X, Fan D (2015), The epithelial-mesenchymal transition and cancer stem cells: Functional and mechanistic links. Curr Pharm Des 21, 10, 1279-1291. PMID: 25506898.

20. Zheng X, Carstens JL, Kim J, Scheible M, Kaye J, Sugimoto H, Wu CC, LeBleu VS, Kalluri R (2015), Epithelial-to-mesenchymal transition is dispensable for metastasis but induces chemoresistance in pancreatic cancer. Nature 527 7579, 525-530. https://doi.org/10.1038/nature16064.

21. Bryant DM, Mostov KE (2008), From cells to organs: Building polarized tissue. Nat Rev Mol Cell Biol 9, 11, 887-901. https://doi.org/10.1038/nrm2523.

22. Brücher BLDM, Jamall IS (2014), Epistemology of the origin of cancer: A New paradigm. BMC Cancer 14, 1-15. https://doi.org/10.1186/1471-2407-14-331.

23. Fata JE, Werb Z, Bissell MJ (2004), Regulation of mammary gland branching morphogenesis by the extracellular matrix and its remodeling enzymes. Breast Cancer Res 6, 1, 1-11. https://doi.org/10.1186/bcr634.

24. Kass L, Erler JT, Dembo M, Weaver VM (2007), Mammary epithelial cell: Influence of extracellular matrix composition and organization during development and tumorigenesis. Int J Biochem Cell Biol 39, 11, 1987-1994. https://doi.org/ 10.1016/j.biocel.2007.06.025.

25. Kopitz C, Gerg M, Bandapalli OR, Ister D, Pennington CJ, Hauser S, Flechsig C, Krell HW, Antolovic D, Brew K, Nagase H, Stangl M, von Weyhern CW, Brücher BL, Brand K, Coussens LM, Edwards DR, Krüger A (2007), Tissue inhibitor of metalloproteinases-1 promotes liver metastasis by induction of hepatocyte growth factor signaling. Cancer Res 67, 18, 8615-8623. https://doi.org/10.1158/0008-5472. CAN-07-0232.

26. Gerg M, Kopitz C, Schaten S, Tschukes A, Kahlert C, Stangl M, von Weyhern CW, Brücher BL, Edwards DR, Brand K, Krüger A (2008), Distinct functionality of tumor cell-derived gelatinases during formation of liver metastases. Mol Cancer Res 6, 3, 341-351. https://doi.org/10.1158/ 1541-7786.MCR-07-2032.

27. Caruso R, Fina D, Peluso I, Fantini MC, Tosti C, Del Vecchio Blanco G, Paoluzi OA, Caprioli F, Andrei F, Stolfi C, Romano M, Ricci V, MacDonald TT, Pallone F, Monteleone G (2007), IL-21 is highly produced in Helicobacter pylori-infected gastric mucosa and promotes 
gelatinases synthesis. J Immunol 178, 9, 5957-5965. PMID: 17442980.

28. Brücher BLDM, Jamall IS (2019), Undervalued ubiquitous proteins. 4open 2, 7, 1-13. https://doi.org/10.1051/fopen/ 2019002.

29. Brücher BLDM, Jamall IS (2019), Chronic inflammation evoked by pathogenic stimulus during carcinogenesis. 4open 2, 8, 1-22. https://doi.org/10.1051/fopen/2018006.

30. Brücher BLDM, Jamall IS (2019), Eicosanoids in carcinogenesis. 4open 2, 9, 1-34. https://doi.org/10.1051/fopen/ 2018008.

31. Brücher BLDM, Jamall IS (2014), Cell-cell communication in tumor microenvironment, carcinogenesis and anticancer treatment. Cell Physiol Biochem 34, 2, 213-243. https://doi.org/10.1159/000362978.

32. Eskeland G (1966), Regeneration of parietal peritoneum in rats. 1. A light microscopical study. Acta Pathol Microbiol Scand 68, 3, 355-378. PMID: 5959843.

33. Eskeland G, Kjaerheim A (1966), Regeneration of parietal peritoneum in rats. 2. An electron microscopical study. Acta Pathol Microbiol Scand 68, 3, 379-395. PMID: 5959844.

34. Kitamura J, Uemura M, Kurozumi M, Sonobe M, Manabe T, Hiai H, Date H, Kinoshita K (2015), Chronic lung injury by constitutive expression of activation-induced cytidine deaminase leads to focal mucous cell metaplasia and cancer. PLoS One 10, 2, e0117986. https://doi.org/10.1371/journal.pone.0117986. Erratum in: PLoS One 2015, 10(8), $\mathrm{e} 0136807$.

35. Thiery JP, Acloque H, Huang RY, Nieto MA (2009), Epithelial-mesenchymal transitions in development and disease. Cell 139, 5, 871-890. https://doi.org/10.1016/ j.cell.2009.11.007.

36. Mani SA, Guo W, Liao MJ, Eaton EN, Ayyanan A, Zhou AY, Brooks M, Reinhard F, Zhang CC, Shipitsin M, Campbell LL, Polyak K, Brisken C, Yang J, Weinberg RA (2008), The epithelial-mesenchymal transition generates cells with properties of stem cells. Cell 133, 4, 704-715. https://doi.org/10.1016/j.cell.2008.03.027.

37. Morel AP, Lievre M, Thomas C, Hinkal G, Ansieau S, Puisieux A (2008), Generation of breast cancer stem cells through epithelial-mesenchymal transition. PLoS One 3, 8, e2888. https://doi.org/10.1371/journal.pone.0002888.

38. Shahbazian MD, Grunstein M (2007), Functions of sitespecific histone acetylation and deacetylation. Annu Rev Biochem 76, 75-100. https://doi.org/10.1146/annurev. biochem.76.052705.162114.

39. Haberland M, Mokalled MH, Montgomery RL, Olson EN (2009), Epigenetic control of skull morphogenesis by histone deacetylase 8. Genes Dev 23, 14, 1625-1630. https://doi. org/10.1101/gad.1809209.

40. Yang XJ, Seto E (2008), The Rpd3/Hda1 family of lysine deacetylases: From bacteria and yeast to mice and men. Nat Rev Mol Cell Biol 9, 3, 206-218. https://doi.org/10.1038/ nrm2346.

41. Saito S, Zhuang Y, Suzuki T, Ota Y, Bateman ME, Alkhatib AL, Morris GF, Lasky JA (2019), HDAC8 inhibition ameliorates pulmonary fibrosis. Am J Physiol Lung Cell Mol Physiol 316, 1, L175-L186. https://doi.org/ 10.1152/ajplung.00551.2017.

42. Oehme I, Deubzer HE, Wegener D, Pickert D, Linke JP, Hero B, Kopp-Schneider A, Westermann F, Ulrich SM, von Deimling A, Fischer M, Witt O (2009), Histone deacetylase 8 in neuroblastoma tumorigenesis. Clin Cancer Res 15, 1, 91-99. https://doi.org/10.1158/1078-0432.CCR-08-0684.

43. Vannini A, Volpari C, Filocamo G, Casavola EC, Brunetti M, Renzoni D, Chakravarty P, Paolini C, De Francesco R, Gallinari P, Steinkühler C, Di Marco S (2004), Crystal structure of a eukaryotic zinc-dependent histone deacetylase, human HDAC8, complexed with a hydroxamic acid inhibitor. Proc Natl Acad Sci USA 101, 42, 15064-15069. https://doi.org/10.1073/pnas.0404603101.

44. Wang LT, Chiou SS, Chai CY, Hsi E, Wang SN, Huang SK, Hsu SH (2017), Aryl hydrocarbon receptor regulates histone deacetylase 8 expression to repress tumor suppressive activity in hepatocellular carcinoma. Oncotarget 8, 5, 7489-7501. https://doi.org/10.18632/oncotarget.9841. Erratum. In: Oncotarget 2018 9(102), 37807.

45. Khurana SS, Riehl TE, Moore BD, Fassan M, Rugge M, Romero-Gallo J, Noto J, Peek RM Jr, Stenson WF, Mills JC (2013), The hyaluronic acid receptor CD44 coordinates normal and metaplastic gastric epithelial progenitor cell proliferation. J Biol Chem 288, 22, 16085-16097. https://doi.org/10.1074/jbc.M112.445551.

46. Orian-Rousseau V (2015), CD44 acts as a signaling platform controlling tumor progression and metastasis. Front Immunol 6, 154 . https://doi.org/ 10.3389/fimmu.2015.00154.

47. Zhang F, Li T, Han L, Qin P, Wu Z, Xu B, Gao Q, Song Y (2018), TGF $\beta 1$-induced down-regulation of microRNA-138 contributes to epithelial-mesenchymal transition in primary lung cancer cells. Biochem Biophys Res Commun 496, 4, 1169-1175. https://doi.org/10.1016/j.bbrc.2018.01.164.

48. Kidan N, Khamaisie H, Ruimi N, Roitman S, Eshel E, Dally N, Ruthardt M, Mahajna J (2017), Ectopic expression of snail and twist in $\mathrm{Ph}+$ leukemia cells upregulates CD44 expression and alters their differentiation potential. J Cancer 8, 19, 3952-3968. https://doi.org/10.7150/ jca.19633.

49. Walter J, Schirrmacher V, Mosier D (1995), Induction of CD44 expression by the Epstein-Barr virus latent membrane protein LMP1 is associated with lymphoma dissemination. Int J Cancer 61, 3, 363-369. Erratum in: Int J Cancer 1995, 63(2), 318.

50. Groma V, Kazanceva A, Nora-Krukle Z, Murovska M (2012), Oropharyngeal malignant epithelial cell, lymphocyte and macrophage CD44 surface receptors for hyaluronate are expressed in sustained EBV infection: Immunohistochemical data and EBV DNA tissue indices. Pathol Res Pract 208, 9, 518-526. https://doi.org/10.1016/ j.prp.2012.05.017.

51. Chong JM, Fukayama M, Hayashi Y, Funata N, Takizawa T, Koike M, Muraoka M, Kikuchi-Yanoshita R, Miyaki M, Mizuno S (1997), Expression of CD44 variants in gastric carcinoma with or without Epstein-Barr virus. Int J Cancer 74, 4, 450-454. PMID: 9291438.

52. Lee MA, Hong YS, Kang JH, Lee KS, You JY, Lee KY, Park CH (2004), Detection of Epstein-Barr virus by PCR and expression of LMP1, p53, CD44 in gastric cancer. Korean J Intern Med 19, 1, 43-47. PMCID: PMC4531546.

53. Gee K, Kozlowski M, Kryworuchko M, Diaz-Mitoma F, Kumar A (2001), Differential effect of IL-4 and IL-13 on CD44 expression in the Burkitt's lymphoma B cell line BL30/B95-8 and in Epstein-Barr virus (EBV) transformed human B cells: loss of IL-13 receptors on Burkitt's lymphoma B cells. Cell Immunol 211, 2, 131-142. https://doi.org/10.1006/cimm.2001.1829.

54. Park GB, Kim D, Kim YS, Kim S, Lee HK, Yang JW, Hur DY (2014), The Epstein-Barr virus causes epithelialmesenchymal transition in human corneal epithelial cells via Syk/src and Akt/Erk signaling pathways. Invest Ophthalmol Vis Sci 55, 3, 1770-1779. https://doi.org/10.1167/ iovs.13-12988.

55. Liu XM, Xu CX, Zhang LF, Huang LH, Hu TZ, Li R, Xia XJ, Xu LY, Luo L, Jiang XX, Li M (2017), PBX1 attributes 
as a determinant of connexin 32 downregulation in Helicobacter pylori-related gastric carcinogenesis. World J Gastroenterol 23, 29, 5345-5355. https://doi.org/10.3748/ wjg.v23.i29.5345.

56. Jee H, Nam KT, Kwon HJ, Han SU, Kim DY (2011), Altered expression and localization of connexin32 in human and murine gastric carcinogenesis. Dig Dis Sci 56, 5, 13231332. https://doi.org/10.1007/s10620-010-1467-z.

57. Hudry B, Thomas-Chollier M, Volovik Y, Duffraisse M, Dard A, Frank D, Technau U, Merabet S (2014), Molecular insights into the origin of the Hox-TALE patterning system, eLife 18, 3, e01939. https://doi.org/10.7554/eLife.01939.

58. Longobardi E, Penkov D, Mateos D, De Florian G, Torres M, Blasi F (2014), Biochemistry of the tale transcription factors PREP, MEIS, and PBX in vertebrates. Dev Dyn 243, 1, 59-75. https://doi.org/10.1002/dvdy.24016.

59. Blasi F, Bruckmann C (2017), A tale of TALE, PREP1, PBX1, and MEIS1: Interconnections and competition in cancer. Bioessays 39, 5. https://doi.org/10.1002/bies. 201600245.

60. Crijns AP, de Graeff P, Geerts D, Ten Hoor KA, Hollema H, van der Sluis T, Hofstra RM, de Bock GH, de Jong S, van der Zee AG, de Vries EG (2007), MEIS and PBX homeobox proteins in ovarian cancer. Eur J Cancer 43, 17, 2495-2505. https://doi.org/10.1016/j.ejca.2007.08.025.

61. Hisa T, Spence SE, Rachel RA, Fujita M, Nakamura T, Ward JM, Devor-Henneman DE, Saiki Y, Kutsuna H, Tessarollo L, Jenkins NA, Copeland NG (2004), Hematopoietic, angiogenic and eye defects in Meis1 mutant animals. EMBO J 23, 2, 450-459. https://doi.org/10.1038/ sj.emboj.7600038.

62. Jones TA, Flomen RH, Senger G, Nizetić D, Sheer D (2000), The homeobox gene MEIS1 is amplified in IMR-32 and highly expressed in other neuroblastoma cell lines. Eur J Cancer 36, 18, 2368-2374. PMID: 11094311.

63. Sabates-Bellver J, Van der Flier LG, de Palo M, Cattaneo E, Maake C, Rehrauer H, Laczko E, Kurowski MA, Bujnicki JM, Menigatti M, Luz J, Ranalli TV, Gomes V, Pastorelli A, Faggiani R, Anti M, Jiricny J, Clevers H, Marra G (2007), Transcriptome profile of human colorectal adenomas. Mol Cancer Res 5, 12, 1263-1275. https://doi.org/ 10.1158/1541-7786.MCR-07-0267.

64. Crist RC, Roth JJ, Waldman SA, Buchberg AM (2011), A conserved tissue-specific homeodomain-less isoform of MEIS1 is downregulated in colorectal cancer. PLoS One 6, 8, e23665. https://doi.org/10.1371/journal.pone. 0023665 .

65. Song F, Wang H, Wang Y (2017), Myeloid ecotropic viral integration site 1 inhibits cell proliferation, invasion or migration in human gastric cancer. Oncotarget 8, 52, 90050-90060. https://doi.org/10.18632/oncotarget.21376.

66. Zhu J, Cui L, Xu A, Yin X, Li F, Gao J (2017), MEIS1 inhibits clear cell renal cell carcinoma cells proliferation and in vitro invasion or migration. BMC Cancer 17, 1, 176. https://doi.org/10.1186/s12885-017-3155-2.

67. Zhu X, Wei L, Bai Y, Wu S, Han S (2017), FoxC1 promotes epithelial-mesenchymal transition through PBX1 dependent transactivation of ZEB2 in esophageal cancer. Am J Cancer Res 7, 8, 1642-1653. PMCID: PMC5574937.

68. Bellaoui M, Pidkowich MS, Samach A, Kushalappa K, Kohalmi SE, Modrusan Z, Crosby WL, Haughn GW (2001), The Arabidopsis BELL1 and KNOX TALE homeodomain proteins interact through a domain conserved between plants and animals. Plant Cell 13, 11, 2455-2470. PMCID: PMC139464.

69. Feng Y, Li L, Zhang X, Zhang Y, Liang Y, Lv J, Fan Z, Guo J, Hong T, Ji B, Ji Q, Mei G, Ding L, Zhang S, Xu X, Ye Q
(2015), Hematopoietic pre-B cell leukemia transcription factor interacting protein is overexpressed in gastric cancer and promotes gastric cancer cell proliferation, migration, and invasion. Cancer Sci 106, 10, 1313-1322. https://doi. org $/ 10.1111 /$ cas. 12754 .

70. He C, Wang Z, Zhang L, Yang L, Li J, Chen X, Zhang J, Chang Q, Yu Y, Liu B, Zhu Z (2017), A hydrophobic residue in the TALE homeodomain of PBX1 promotes epithelial-to-mesenchymal transition of gastric carcinoma. Oncotarget 8, 29, 46818-46833. https://doi.org/10.18632/ oncotarget.17473.

71. Risolino M, Mandia N, Iavarone F, Dardaei L, Longobardi E, Fernandez S, Talotta F, Bianchi F, Pisati F, Spaggiari L, Harter PN, Mittelbronn M, Schulte D, Incoronato M, Di Fiore PP, Blasi F, Verde P (2014), Transcription factor PREP1 induces EMT and metastasis by controlling the TGF- $\beta$-SMAD3 pathway in non-small cell lung adenocarcinoma. Proc Natl Acad Sci USA 111, 36, E3775-E3784. https://doi.org/10.1073/pnas.1407074111.

72. Argiropoulos B, Yung E, Xiang P, Lo CY, Kuchenbauer F, Palmqvist L, Reindl C, Heuser M, Sekulovic S, Rosten P, Muranyi A, Goh SL, Featherstone M, Humphries RK (2010), Linkage of the potent leukemogenic activity of Meis1 to cell-cycle entry and transcriptional regulation of cyclin D3. Blood 115, 20, 4071-4482. https://doi.org/ 10.1182/blood-2009-06-225573.

73. Montoya-Durango DE, Ramos KS (2011), Retinoblastoma family of proteins and chromatin epigenetics: A repetitive story in a few LINEs. Biomol Concepts 2, 4, 233-245. https://doi.org/10.1515/bmc.2011.027.

74. Mihara K, Cao XR, Yen A, Chandler S, Driscoll B, Murphree AL, T'Ang A, Fung YK (1989), Cell cycledependent regulation of phosphorylation of the human retinoblastoma gene product. Science 246, 4935, 1300-1303.

75. Goodrich DW, Wang NP, Qian YW, Lee EY, Lee WH (1991), The retinoblastoma gene product regulates progression through the G1 phase of the cell cycle. Cell 67, 2, 293302 .

76. Narasimha AM, Kaulich M, Shapiro GS, Choi YJ, Sicinski P, Dowdy SF (2014), Cyclin D activates the Rb tumor suppressor by mono-phosphorylation. eLife 3, e02872. https://doi.org/10.7554/eLife.02872.

77. Sobhani N, Corona SP, Zanconati F, Generali D (2017), Cyclin dependent kinase 4 and 6 inhibitors as novel therapeutic agents for targeted treatment of malignant mesothelioma. Genes Cancer 8, 3-4, 495-496. https://doi. org/10.18632/genesandcancer.138.

78. Ewens KG, Bhatti TR, Moran KA, Richards-Yutz J, Shields CL, Eagle RC, Ganguly A (2017), Phosphorylation of $\mathrm{pRb}$ : Mechanism for RB pathway inactivation in MYCNamplified retinoblastoma. Cancer Med 6, 3, 619-630. https://doi.org/10.1002/cam4.1010.

79. Chellappan SP, Hiebert S, Mudryj M, Horowitz JM, Nevins JR (1991), The E2F transcription factor is a cellular target for the RB protein. Cell 65, 6, 1053-1061.

80. Holley SL, Matthias C, Jahnke V, Fryer AA, Strange RC, Hoban PR (2005), Association of cyclin D1 polymorphism with increased susceptibility to oral squamous cell carcinoma. Oral Oncol 41, 2, 156-160. https://doi.org/10.1016/ j.oraloncology.2004.08.005.

81. Al-Salam S, Awwad A, Alashari M (2014), Epstein-Barr virus infection is inversely correlated with the expression of retinoblastoma protein in Reed-Sternberg cells in classic Hodgkin lymphoma. Int J Clin Exp Pathol 7, 11, 7508-7517.

82. Claudio PP, Russo G, Kumar CA, Minimo C, Farina A, Tutton S, Nuzzo G, Giuliante F, Angeloni G, Maria V, Vecchio FM, Campli CD, Giordano A (2004), pRb2/p130, 
vascular endothelial growth factor, p27(KIP1), and proliferating cell nuclear antigen expression in hepatocellular carcinoma: Their clinical significance. Clin Cancer Res 10, 10, 3509-3517. https://doi.org/10.1158/1078-0432.CCR03-0662.

83. Beck TN, Smith CH, Flieder DB, Galloway TJ, Ridge JA, Golemis EA, Mehra R (2017), Head and neck squamous cell carcinoma: Ambiguous human papillomavirus status, elevated p16, and deleted retinoblastoma 1 . Head Neck 39, 3, E34-E39. https://doi.org/10.1002/hed.24604.

84. Claudio PP, Zamparelli A, Garcia FU, Claudio L, Ammirati G, Farina A, Bovicelli A, Russo G, Giordano GG, McGinnis DE, Giordano A, Cardi G (2002), Expression of cell-cycleregulated proteins pRb2/p130, p107, p27(kip1), p53, mdm2, and Ki-67 (MIB-1) in prostatic gland adenocarcinoma. Clin Cancer Res 8, 6, 1808-1815.

85. Munger K, Jones DL (2015), Human papillomavirus carcinogenesis: An identity crisis in the retinoblastoma tumor suppressor pathway. J Virol 89, 9, 4708-4711. https://doi.org/10.1128/JVI.03486-14.

86. Roman A, Munger K (2013), The papillomavirus E7 proteins. Virology 445, 1-2, 138-168. https://doi.org/ 10.1016/j.virol.2013.04.013.

87. Caldeira S, de Villiers EM, Tommasino M (2000), Human papillomavirus E7 proteins stimulate proliferation independently of their ability to associate with retinoblastoma protein. Oncogene 19, 6, 821-826. https://doi.org/10.1038/ sj.onc. 1203375 .

88. Butz K, Geisen C, Ullmann A, Spitkovsky D, Hoppe-Seyler F (1996), Cellular responses of HPV-positive cancer cells to genotoxic anti-cancer agents: repression of E6/E7-oncogene expression and induction of apoptosis. Int J Cancer 68, 4, 506-513.

89. Kerr JF, Wyllie AH, Currie AR (1972), Apoptosis: A basic biological phenomenon with wide-ranging implications in tissue kinetics. Br J Cancer 26, 4, 239-257. PMCID: PMC2008650.

90. Majno G, Joris I (1995), Apoptosis, oncosis, and necrosis. An overview of cell death. Am J Pathol 146, 1, 3-15. PMCID: PMC1870771.

91. Saraste A, Pulkki K (2000), Morphologic and biochemical hallmarks of apoptosis. Cardiovasc Res 45, 3, 528-537. PMID: 10728374.

92. Kroemer G, El-Deiry WS, Golstein P, Peter ME, Vaux D, Vandenabeele P, Zhivotovsky B, Blagosklonny MV, Malorni W, Knight RA, Piacentini M, Nagata S, Melino G, Nomenclature Committee on Cell Death (2005), Classification of cell death: Recommendations of the Nomenclature Committee on Cell Death. Cell Death Differ 12, Suppl 2, 1463-1467. https://doi.org/10.1038/sj.cdd.4401724.

93. Kerr JF, Winterford CM, Harmon BV (1994), Apoptosis. Its significance in cancer and cancer therapy. Cancer 73, 8, 2013-2026. Erratum in: Cancer 73, 12, 3108.

94. Wong RS (2011), Apoptosis in cancer: From pathogenesis to treatment. J Exp Clin Cancer Res 30, 87. https://doi. org/10.1186/1756-9966-30-87.

95. Hengartner M (1998), Apoptosis. Death by crowd control. Science 281, 5381, 1298-1299. PMID: 9735047.

96. Bröker LE, Kruyt FA, Giaccone G (2005), Cell death independent of caspases: A review. Clin Cancer Res 11, 9, 3155-3162. https://doi.org/10.1158/1078-0432.CCR-042223.

97. Kutscher LM, Shaham S (2017), Non-apoptotic cell death in animal development. Cell Death Differ 24, 8, 1326-1336. https://doi.org/10.1038/cdd.2017.20.
98. Reed JC (1997), Bcl-2 family proteins: Regulators of apoptosis and chemoresistance in hematologic malignancies. Semin Hematol 34, 4 Suppl 5, 9-19. PMID: 9408956.

99. Schneider P, Tschopp J (2000), Apoptosis induced by death receptors. Pharm Acta Helv 74, 2-3, 281-286. PMID: 10812970

100. Lerch MM, Gorelick FS (2013), Models of acute and chronic pancreatitis. Gastroenterology 144, 6, 1180-1193. https://doi.org/10.1053/j.gastro.2012.12.043.

101. Pinho AV, Chantrill L, Rooman I (2014), Chronic pancreatitis: A path to pancreatic cancer. Cancer Lett 345, 2, 203209. https://doi.org/10.1016/j.canlet.2013.08.015.

102. Taylor MA, Amin JD, Kirschmann DA, Schiemann WP (2011), Lysyl oxidase contributes to mechanotransductionmediated regulation of transforming growth factor- $\beta$ signaling in breast cancer cells. Neoplasia 13, 5, 406-418.

103. Moon HJ, Finney J, Xu L, Moore D, Welch DR, Mure M (2013), MCF-7 cells expressing nuclear associated lysyl oxidase-like 2 (LOXL2) exhibit an epithelial-to-mesenchymal transition (EMT) phenotype and are highly invasive in vitro. J Biol Chem 288, 42, 30000-30008. https://doi. org $/ 10.1074 /$ jbc.C113.502310.

104. Park JS, Lee JH, Lee YS, Kim JK, Dong SM, Yoon DS (2016), Emerging role of LOXL2 in the promotion of pancreas cancer metastasis. Oncotarget 7, 27, 42539-42552. https://doi.org/10.18632/oncotarget.9918.

105. Ying L, Marino J, Hussain SP, Khan MA, You S, Hofseth AB, Trivers GE, Dixon DA, Harris CC, Hofseth LJ (2005), Chronic inflammation promotes retinoblastoma protein hyperphosphorylation and E2F1 activation. Cancer Res 65, 20, 9132-9136. https://doi.org/10.1158/0008-5472. CAN-05-1358.

106. Moreno-Navarrete JM, Petrov P, Serrano M, Ortega F, García-Ruiz E, Oliver P, Ribot J, Ricart W, Palou A, Bonet ML, Fernández-Real JM (2013), Decreased RB1 mRNA, protein, and activity reflect obesity-induced altered adipogenic capacity in human adipose tissue. Diabetes 62,6 , 1923-1931. https://doi.org/10.2337/db12-0977.

107. Tommasino M, Crawford L (1995), Human papillomavirus E6 and E7: Proteins which deregulate the cell cycle. Bioessays 17, 6, 509-518. https://doi.org/10.1002/bies.950170607.

108. McCormick TM, Canedo NH, Furtado YL, Silveira FA, de Lima RJ, Rosman AD, Almeida Filho GL, Carvalho Mda G (2015), Association between human papillomavirus and Epstein - Barr virus DNA and gene promoter methylation of RB1 and CDH1 in the cervical lesions: A transversal study. Diagn Pathol 10, 59. https://doi.org/10.1186/ s13000-015-0283-3.

109. Cárdenas-Mondragón MG, Carreón-Talavera R, CamorlingaPonce M, Gomez-Delgado A, Torres J, Fuentes-Pananá EM (2013), Epstein Barr virus and Helicobacter pylori co-infection are positively associated with severe gastritis in pediatric patients. PLoS One 8, 4, e62850. https://doi.org/10.1371/ journal.pone.0062850.

110. Cárdenas-Mondragón MG, Torres J, Flores-Luna L, Camorlinga-Ponce M, Carreón-Talavera R, Gomez-Delgado A, Kasamatsu E, Fuentes-Pananá EM (2015), Case-control study of Epstein-Barr virus and Helicobacter pylori serology in Latin American patients with gastric disease. Br J Cancer 112, 12, 1866-7183. https://doi.org/10.1038/bjc.2015.175.

111. Koinuma D, Shinozaki M, Nagano Y, Ikushima H, Horiguchi K, Goto K, Chano T, Saitoh M, Imamura T, Miyazono K, Miyazawa K (2011), RB1CC1 protein positively regulates transforming growth factor-beta signaling through the modulation of Arkadia E3 ubiquitin ligase 
activity. J Biol Chem 286, 37, 32502-32512. https://doi. org/10.1074/jbc.M111.227561.

112. Chano T, Saeki Y, Serra M, Matsumoto K, Okabe H (2002), Preferential expression of RB1-inducible coiled-coil 1 in terminal differentiated musculoskeletal cells. Am J Pathol $161,2,359-364$.

113. Ikebuchi K, Chano T, Ochi Y, Tameno H, Shimada T, Hisa Y, Okabe H (2009), RB1CC1 activates the promoter and expression of RB1 in human cancer. Int J Cancer 125, 4, 861-867. https://doi.org/10.1002/ijc.24466.

114. Chano T, Ikegawa S, Kontani K, Okabe H, Baldini N, Saeki Y (2002), Identification of RB1CC1, a novel human gene that can induce RB1 in various human cells. Oncogene 21, 8, 1295-1298. https://doi.org/10.1038/sj.onc.1205171.

115. Li L, Wang G, Hu JS, Zhang GQ, Chen HZ, Yuan Y, Li YL, Lv XJ, Tian FY, Pan SH, Bai XW, Sun B (2018), RB1CC1enhanced autophagy facilitates PSCs activation and pancreatic fibrogenesis in chronic pancreatitis. Cell Death Dis 9, 10, 952. https://doi.org/10.1038/s41419-018-0980-4.

116. Guo M, Mu Y, Yu D, Li J, Chen F, Wei B, Bi S, Yu J, Liang F (2018), Comparison of the expression of TGF- $\beta 1$, Ecadherin, N-cadherin, TP53, RB1CC1 and HIF- $1 \alpha$ in oral squamous cell carcinoma and lymph node metastases of humans and mice. Oncol Lett 15, 2, 1639-1645. doi: https://doi.org/10.3892/ol.2017.7456.

117. Lo PK, Zhang Y, Yao Y, Wolfson B, Yu J, Han SY, Duru N, Zhou Q (2017), Tumor-associated myoepithelial cells promote the invasive progression of ductal carcinoma in situ through activation of TGF $\beta$ signaling. J Biol Chem 292, 27, 11466-11484. https://doi.org/10.1074/jbc.M117.775080.

118. Brücher BLDM, Jamall IS (2019), Precancerous niche (PCN), a product of fibrosis with remodeling by incessant chronic inflammation. 4open 2, 11, 1-21. https://doi.org/ $10.1051 /$ fopen $/ 2018009$

119. Zhang Q, Dong P, Liu X, Sakuragi N, Guo SW (2017), Enhancer of Zeste homolog 2 (EZH2) induces epithelialmesenchymal transition in endometriosis. Sci Rep 7, 1, 6804. https://doi.org/10.1038/s41598-017-06920-7.

120. Zhou BP, Deng J, Xia W, Xu J, Li YM, Gunduz M, Hung MC (2004), Dual regulation of Snail by GSK-3betamediated phosphorylation in control of epithelial-mesenchymal transition. Nat Cell Biol 6, 931-940.

121. Moreno-Bueno G, Salvador F, Martín A, Floristán A, Cuevas EP, Santos V, Montes A, Morales S, Castilla MA, Rojo-Sebastián A, Martínez A, Hardisson D, Csiszar K, Portillo F, Peinado H, Palacios J, Cano A (2011), Lysyl oxidase-like 2 (LOXL2), a new regulator of cell polarity required for metastatic dissemination of basal-like breast carcinomas. EMBO Mol Med 3, 9, 528-544. https://doi. org/10.1002/emmm.201100156.

122. Salvador F, Martin A, López-Menéndez C, Moreno-Bueno G, Santos V, Vázquez-Naharro A, Santamaria PG, Morales S, Dubus PR, Muinelo-Romay L, López-López R, Tung JC, Weaver VM, Portillo F, Cano A (2017), Lysyl oxidase-like protein LOXL2 promotes lung metastasis of breast cancer. Cancer Res 77, 21, 5846-5859. https://doi.org/10.1158/ 0008-5472.CAN-16-3152.

123. Payne SL, Hendrix MJ, Kirschmann DA (2006), Lysyl oxidase regulates actin filament formation through the p130 (Cas)/Crk/DOCK180 signaling complex. J Cell Biochem 98, 4, 827-837. https://doi.org/10.1002/jcb.20792.

124. Peng L, Ran YL, Hu H, Yu L, Liu Q, Zhou Z, Sun YM, Sun LC, Pan J, Sun LX, Zhao P, Yang ZH (2009), Secreted LOXL2 is a novel therapeutic target that promotes gastric cancer metastasis via the Src/FAK pathway. Carcinogenesis 30, 10, 1660-1669. https://doi.org/10.1093/carcin/bgp178.
125. Ahn SG, Dong SM, Oshima A, Kim WH, Lee HM, Lee SA, Kwon SH, Lee JH, Lee JM, Jeong J, Lee HD, Green JE (2013), LOXL2 expression is associated with invasiveness and negatively influences survival in breast cancer patients. Breast Cancer Res Treat 141, 1, 89-99. https://doi.org/ 10.1007/s10549-013-2662-3.

126. Wiel C, Augert A, Vincent DF, Gitenay D, Vindrieux D, Le Calvé B, Arfi V, Lallet-Daher H, Reynaud C, Treilleux I, Bartholin L, Lelievre E, Bernard D (2013), Lysyl oxidase activity regulates oncogenic stress response and tumorigenesis. Cell Death Dis 4, e855. https://doi.org/10.1038/ cddis.2013.382.

127. Nguyen LT, Song YW, Cho SK (2016), Baicalein inhibits epithelial to mesenchymal transition via downregulation of Cyr61 and LOXL-2 in MDA-MB231 breast cancer cells. Mol Cells 39, 12, 909-914. https://doi.org/10.14348/molcells. 2016.0243.

128. Laczko R, Szauter KM, Jansen MK, Hollosi P, Muranyi M, Molnar J, Fong KS, Hinek A, Csiszar K (2007), Active lysyl oxidase (LOX) correlates with focal adhesion kinase $(\mathrm{FAK}) /$ paxillin activation and migration in invasive astrocytes. Neuropathol Appl Neurobiol 33, 6, 631-643. https://doi.org/10.1111/j.1365-2990.2007.00858.x.

129. Ungewiss C, Rizvi ZH, Roybal JD, Peng DH, Gold KA, Shin DH, Creighton CJ, Gibbons DL (2016), The microRNA-200/ Zeb1 axis regulates ECM-dependent $\beta 1$-integrin/FAK signaling, cancer cell invasion and metastasis through CRKL. Sci Rep 6, 18652. https://doi.org/10.1038/srep18652.

130. Oakes PW, Bidone TC, Beckham Y, Skeeters AV, RamirezSan Juan GR, Winter SP, Voth GA, Gardel ML (2018), Lamellipodium is a myosin-independent mechanosensor. Proc Natl Acad Sci USA 115, 11, 2646-2651. https://doi. org $/ 10.1073 /$ pnas. 1715869115 .

131. Krause M, Gautreau A (2014), Steering cell migration: Lamellipodium dynamics and the regulation of directional persistence. Nat Rev Mol Cell Biol 15, 9, 577-590. https://doi.org/10.1038/nrm3861.

132. Hall A (1998), Rho GTPases and the actin cytoskeleton. Science 279, 5350, 509-514. PMID: 9438836.

133. Bae YH, Mui KL, Hsu BY, Liu SL, Cretu A, Razinia Z, Xu T, Puré E, Assoian RK (2014), A FAK-Cas-Rac-lamellipodin signaling module transduces extracellular matrix stiffness into mechanosensitive cell cycling. Sci Signal 7, 330, ra57. https://doi.org/10.1126/scisignal.2004838

134. Xiao X, Fischbach S, Zhang T, Chen C, Sheng Q, Zimmerman R, Patnaik S, Fusco J, Ming Y, Guo P, Shiota C, Prasadan K, Gangopadhyay N, Husain SZ, Dong H, Gittes GK (2017), SMAD3/Stat3 signaling mediates $\beta$-cell epithelial-mesenchymal transition in chronic pancreatitisrelated diabetes. Diabetes 66, 10, 2646-2658. https://doi. org $/ 10.2337 / \mathrm{db} 17-0537$.

135. Cuevas EP, Eraso P, Mazón MJ, Santos V, Moreno-Bueno G, Cano A, Portillo F (2017), LOXL2 drives epithelialmesenchymal transition via activation of IRE1-XBP1 signalling pathway. Sci Rep 7, 44988. https://doi.org/ $10.1038 /$ srep44988.

136. Brücher BLDM, Becker KF, Sarbia M (2006), Expression of proteins involved in epithelial-mesenchymal transition in spindle cell (pseudosarcomatous) carcinoma of the esophagus. J Clin Gastroenterol 40, S164-S165. September 2006. http://journals.lww.com/jcge/Citation/2006/09001/ Expression of proteins involved in.5.aspx.

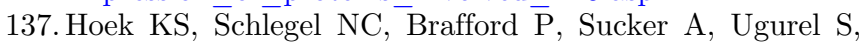
Kumar R, Weber BL, Nathanson KL, Phillips DJ, Herlyn M, Schadendorf D, Dummer R (2006), Metastatic potential of melanomas defined by specific gene expression profiles 
with no BRAF signature. Pigment Cell Res 19, 4, 290-302. https://doi.org/10.1111/j.1600-0749.2006.00322.x.

138. Li R, Dong T, Hu C, Lu J, Dai J, Liu P (2017), Salinomycin repressed the epithelial-mesenchymal transition of epithelial ovarian cancer cells via downregulating Wnt/ $\beta$-catenin pathway. Onco Targets Ther 10, 1317-1325. https://doi. org/10.2147/OTT.S126463.

139. Chen LJ, Ye H, Zhang Q, Li FZ, Song LJ, Yang J, Mu Q, Rao SS, Cai PC, Xiang F, Zhang JC, Su Y, Xin JB, Ma WL (2015), Bleomycin induced epithelial-mesenchymal transition (EMT) in pleural mesothelial cells. Toxicol Appl Pharmacol 283, 2, 75-82. https://doi.org/10.1016/ j.taap.2015.01.004.

140. Zou XZ, Gong ZC, Liu T, He F, Zhu TT, Li D, Zhang WF, Jiang JL, Hu CP (2017), Involvement of epithelialmesenchymal transition afforded by activation of LOX-1/ TGF- $\beta 1 /$ KLF6 signaling pathway in diabetic pulmonary fibrosis. Pulm Pharmacol Ther 44, 70-77. https://doi.org/ 10.1016/j.pupt.2017.03.012.

141. Xu Q, Isaji T, Lu Y, Gu W, Kondo M, Fukuda T, Du Y, Gu $\mathrm{J}$ (2012), Roles of N-acetylglucosaminyltransferase III in epithelial-to-mesenchymal transition induced by transforming growth factor $\beta 1$ (TGF- $\beta 1$ ) in epithelial cell lines. J Biol Chem 287, 20, 16563-16574. https://doi.org/10.1074/jbc. M111.262154.

142. Khan GJ, Gao Y, Gu M, Wang L, Khan S, Naeem F, Yousef BA, Roy D, Semukunzi H, Yuan S, Sun L (2018), TGF- $\beta 1$ causes EMT by regulating $\mathrm{N}$-acetyl glucosaminyl transferases via downregulation of non muscle myosin II-A through JNK/P38/PI3K pathway in lung cancer. Curr Cancer Drug Targets 18, 2, 209-219. https://doi.org/ 10.2174/1568009617666170807120304.

143. Barker TH, Dysart MM, Brown AC, Douglas AM, Fiore VF, Russell AG, Health Review Committee HEI (2014), Synergistic effects of particulate matter and substrate stiffness on epithelial-to-mesenchymal transition. Res Rep Health Eff Inst 182, 3-41. https://www.healtheffects.org/ system/files/Barker-182.pdf.

144. Wei SC, Fattet L, Tsai JH, Guo Y, Pai VH, Majeski HE, Chen AC, Sah RL, Taylor SS, Engler AJ, Yang J (2015), Matrix stiffness drives epithelial-mesenchymal transition and tumour metastasis through a TWIST1-G3BP2 mechanotransduction pathway. Nat Cell Biol 17, 5, 678-688. https://doi.org/10.1038/ncb3157.

145. Lee KW, Yeo SY, Sung CO, Kim SH (2015), Twist1 is a key regulator of cancer-associated fibroblasts. Cancer Res 75, 1, 73-85. https://doi.org/10.1158/0008-5472.CAN-140350.

146. Yeo SY, Ha SY, Lee KW, Cui Y, Yang ZT, Xuan YH, Kim SH (2017), Twist1 is highly expressed in cancer-associated fibroblasts of esophageal squamous cell carcinoma with a prognostic significance. Oncotarget 8, 39, 65265-65280. https://doi.org/10.18632/oncotarget.17941.

147. Yeo SY, Lee KW, Shin D, An S, Cho KH, Kim SH (2018), A positive feedback loop bi-stably activates fibroblasts. Nat Commun 9, 1, 3016. https://doi.org/10.1038/s41467-01805274-6.

148. Moreira DM, Howard LE, Sourbeer KN, Amarasekara HS, Chow LC, Cockrell DC, Pratson CL, Hanyok BT, Aronson WJ, Kane CJ, Terris MK, Amling CL, Cooperberg MR, Freedland SJ (2017), Predicting time from metastasis to overall survival in castration-resistant prostate cancer: Results from SEARCH. Clin Genitourin Cancer 15, 1, 6066.e2. https://doi.org/10.1016/j.clgc.2016.08.018.

149. National Cancer Institute (2017), SEER cancer stat facts: Prostate cancer, http://seer.cancer.gov/statfacts/html/ prost.html. Accessed September 25, 2018.
150. Chiu SJ, Chao JI, Lee YJ, Hsu TS (2008), Regulation of gamma-H2AX and securin contribute to apoptosis by oxaliplatin via a p38 mitogen-activated protein kinase dependent pathway in human colorectal cancer cells. Toxicol Lett 179, 63-70. https://doi.org/10.1016/ j.toxlet.2008.04.004.

151. Huang S, Liu Q, Liao Q, Wu Q, Sun B, Yang Z, Hu X, Tan M, Li L (2018), Interleukin-6/signal transducer and activator of transcription 3 promotes prostate cancer resistance to androgen deprivation therapy via regulating pituitary tumor transforming gene 1 expression. Cancer Sci 109, 3, 678-687. https://doi.org/10.1111/cas.13493.

152. Ghayad SE, Vendrell JA, Bieche I, Spyratos F, Dumontet C, Treilleux I, Lidereau R, Cohen PA (2009), Identification of TACC1, NOV, and PTTG1 as new candidate genes associated with endocrine therapy resistance in breast cancer. J Mol Endocrinol 42, 2, 87-103. https://doi.org/ 10.1677/JME-08-0076.

153. Chen WS, Yu YC, Lee YJ, Chen JH, Hsu HY, Chiu SJ (2010), Depletion of securin induces senescence after irradiation and enhances radiosensitivity in human cancer cells regardless of functional p53 expression. Int J Radiat Oncol Biol Phys 77, 566-574. https://doi.org/10.1016/j. ijrobp.2009.12.013.

154. Yu YC, Yang PM, Chuah QY, Huang YH, Peng CW, Lee YJ, Chiu SJ (2013), Radiation-induced senescence in securin-deficient cancer cells promotes cell invasion involving the IL-6/STAT3 and PDGF-BB/PDGFR pathways. Sci Rep 3, 1675. https://doi.org/10.1038/srep01675.

155. Huang YH, Yang PM, Chuah QY, Lee YJ, Hsieh YF, Peng CW, Chiu SJ (2014), Autophagy promotes radiationinduced senescence but inhibits bystander effects in human breast cancer cells. Autophagy 10, 7, 1212-1228. https://doi.org/10.4161/auto.28772.

156. Wieschaus E, Nüsslein-Volhard C, Jürgens G (1984), Mutations affecting the pattern of the larval cuticle in Drosophila melanogaster III. Zygotic loci on the X-chromosome and fourth chromosome. Wilhelm Rouxs Arch Dev Biol 193, 5, 296-387. https://doi.org/10.1007/BF00848158.

157. Ozawa M, Baribault H, Kemler R (1989), The cytoplasmic domain of the cell adhesion molecule uvomorulin associates with three independent proteins structurally related in different species. EMBO J 8, 6, 1711-1717.

158. Valenta T, Hausmann G, Basler K (2012), The many faces and functions of $\beta$-catenin. EMBO J 31, 12, 2714-2736. https://doi.org/10.1038/emboj.2012.150.

159. van Ooyen A, Nusse R (1984), Structure and nucleotide sequence of the putative mammary oncogene int-1; proviral insertions leave the protein-encoding domain intact. Cell 39, 1, 233-240. https://doi.org/10.1016/00928674(84)90209-5.

160. Valkenburg KC, Graveel CR, Zylstra-Diegel CR, Zhong Z, Williams BO (2011), Wnt/beta-catenin signaling in normal and cancer stem cells. Cancers (Basel) 3, 2, 2050-2079. https://doi.org/10.3390/cancers3022050.

161. Khramtsov AI, Khramtsova GF, Tretiakova M, Huo D, Olopade OI, Goss KH (2010), Wnt/beta-catenin pathway activation is enriched in basal-like breast cancers and predicts poor outcome. Am J Pathol 176, 6, 2911-2920. https://doi.org/10.2353/ajpath.2010.091125.

162. Tao J, Calvisi DF, Ranganathan S, Cigliano A, Zhou L, Singh S, Jiang L, Fan B, Terracciano L, Armeanu-Ebinger S, Ribback S, Dombrowski F, Evert M, Chen X, Monga SPS (2014), Activation of beta-catenin and Yap1 in human hepatoblastoma and induction of hepatocarcinogenesis in mice. Gastroenterology 147, 3, 690-701. https://doi.org/ 10.1053/j.gastro.2014.05.004. 
163. Kobayashi M, Honma T, Matsuda Y, Suzuki Y, Narisawa R, Ajioka Y, Asakura H (2000), Nuclear translocation of betacatenin in colorectal cancer. Br J Cancer 82, 10, 16891693. https://doi.org/10.1054/bjoc.1999.1112.

164. Damsky WE, Curley DP, Santhanakrishnan M, Rosenbaum LE, Platt JT, Gould Rothberg BE, Taketo MM, Dankort D, Rimm DL, McMahon M, Bosenberg M (2011), $\beta$-catenin signaling controls metastasis in Braf-activated PTENdeficient melanomas. Cancer Cell 20, 6, 741-754. https://doi.org/10.1016/j.ccr.2011.10.030.

165. Gekas C, D'Altri T, Aligue R, Gonzalez J, Espinosa L, Bigas A (2016), $\beta$-catenin is required for T-cell leukemia initiation and MYC transcription downstream of Notch1. Leukemia 30, 10, 2002-2010. https://doi.org/10.1038/ leu.2016.106.

166. Bernstein E, Caudy AA, Hammond SM, Hannon GJ (2001), Role for a bidentate ribonuclease in the initiation step of RNA interference. Nature 409, 6818, 363-366. https://doi. org $/ 10.1038 / 35053110$.

167. To SKY, Mak ASC, Eva Fung YM, Che CM, Li SS, Deng W, Ru B, Zhang J, Wong AST (2017), $\beta$-catenin downregulates Dicer to promote ovarian cancer metastasis. Oncogene $36, \quad 43, \quad 5927-5938$. https://doi.org/10.1038/ onc. 2017.185 .

168. Hirota M, Watanabe K, Hamada S, Sun Y, Strizzi L, Mancino M, Nagaoka T, Gonzales M, Seno M, Bianco C, Salomon DS (2008), Smad2 functions as a co-activator of canonical Wnt/beta-catenin signaling pathway independent of Smad4 through histone acetyltransferase activity of p300. Cell Signal 20, 9, 1632-1641. https://doi.org/10.1016/ j.cellsig.2008.05.003.

169. Gracz AD, Magness ST (2011), Sry-box (Sox) transcription factors in gastrointestinal physiology and disease. Am J Physiol Gastrointest Liver Physiol 300, 4, G503-G515. https://doi.org/10.1152/ajpgi.00489.2010.

170. Bowles J, Schepers G, Koopman P (2000), Phylogeny of the SOX family of developmental transcription factors based on sequence and structural indicators. Dev Biol 227, 2, 239255. https://doi.org/10.1006/dbio.2000.9883.

171. Tiwari N, Tiwari VK, Waldmeier L, Balwierz PJ, Arnold P, Pachkov M, Meyer-Schaller N, Schübeler D, van Nimwegen E, Christofori G (2013), Sox4 is a master regulator of epithelial-mesenchymal transition by controlling Ezh2 expression and epigenetic reprogramming. Cancer Cell 23, 6, 768-783. https://doi.org/10.1016/j.ccr.2013.04.020.

172. Lin CM, Fang CL, Hseu YC, Chen CL, Wang JW, Hsu SL, Tu MD, Hung ST, Tai C, Uen YH, Lin KY (2013), Clinical and prognostic implications of transcription factor SOX4 in Patients with Colon Cancer. PLoS One 8, 6, e67128. https://doi.org/10.1371/journal.pone.0067128.

173. Fang CL, Hseu YC, Lin YF, Hung ST, Tai C, Uen YH, Lin KY (2012), Clinical and prognostic association of transcription factor SOX4 in gastric cancer. PLoS One 7, 12, e52804. https://doi.org/10.1371/journal.pone.0052804.

174. Wang D, Hao T, Pan Y, Qian X, Zhou D (2015), Increased expression of SOX4 is a biomarker for malignant status and poor prognosis in patients with non-small cell lung cancer. Mol Cell Biochem 402, 1-2, 75-82. https://doi.org/ 10.1007/s11010-014-2315-9.

175. Bao ZQ, Zhang CC, Xiao YZ, Zhou JS, Tao YS, Chai DM (2016), Over-expression of Sox 4 and $\beta$-catenin is associated with a less favorable prognosis of osteosarcoma. J Huazhong Univ Sci Technol Med Sci 36, 2, 193-199. https://doi.org/ 10.1007/s11596-016-1565-z.

176. Wu D, Pan H, Zhou Y, Zhang Z, Qu P, Zhou J, Wang W (2015), Upregulation of microRNA-204 inhibits cell proliferation, migration and invasion in human renal cell carcinoma cells by downregulating SOX4. Mol Med Rep 12, 5, 7059-7064. https://doi.org/10.3892/mmr. 2015.4259 .

177. Lou J, Zhang K, Chen J, Gao Y, Wang R, Chen LB (2015), Prognostic significance of SOX-1 expression in human hepatocellular cancer. Int J Clin Exp Pathol 8, 5, 54115418.

178. Brücher BLDM, Li Y, Schnabel P, Daumer M, Wallace TJ, Kube R, Zilberstein B, Steele S, Voskuil JL, Jamall IS (2016), Genomics, microRNA, epigenetics, and proteomics for future diagnosis, treatment and monitoring response in upper GI cancers. Clin Transl Med 5, 1, 1-16. https://doi. org/10.1186/s40169-016-0093-6.

179. Matsushima K, Isomoto H, Inoue N, Nakayama T, Hayashi T, Nakayama M, Nakao K, Hirayama T, Kohno S (2011), MicroRNA signatures in Helicobacter pylori-infected gastric mucosa. Int J Cancer 128, 2, 361-370. https://doi.org/ $10.1002 /$ ijc. 25348 .

180. Zhou X, Li L, Su J, Zhang G (2014), Decreased miR-204 in $H$. pylori-associated gastric cancer promotes cancer cell proliferation and invasion by targeting SOX4. PLoS One 9, 7, e101457. https://doi.org/10.1371/journal.pone.0101457.

181. Jiang L, Zhao Z, Zheng L, Xue L, Zhan Q, Song Y (2017), Downregulation of miR-503 promotes ESCC cell proliferation, migration, and invasion by targeting cyclin D1. Genom Proteom Bioinform 15, 3, 208-217. https://doi.org/ 10.1016/j.gpb.2017.04.003.

182. Brücher BLDM, Keller G, Werner M, Müller U, Lassmann S, Cabras AC, Fend F, Busch R, Stein H, Allescher HD, Molls M, Siewert JR, Höfler H, Specht K (2009), Using QRT-PCR to measure Cyclin D1, TS, TP, DPD, and Her-2/ neu as predictors for response, survival, and recurrence in patients with esophageal squamous cell carcinoma following radiochemotherapy. Int $\mathrm{J}$ Colorectal Dis 24, 1, 69-77. https://doi.org/10.1007/s00384-008-0562-5.

183. Wang T, Zhang L, Shi C, Sun H, Wang J, Li R, Zou Z, Ran $\mathrm{X}$, Su Y (2012), TGF- $\beta$-induced miR-21 negatively regulates the antiproliferative activity but has no effect on EMT of TGF- $\beta$ in HaCaT cells. Int $\mathrm{J}$ Biochem Cell Biol 44, 2, 366-376. https://doi.org/10.1016/j.biocel.2011.11.012.

184. Xie L, Wu M, Lin H, Liu C, Yang H, Zhan J, Sun S (2014), An increased ratio of serum miR-21 to miR-181a levels is associated with the early pathogenic process of chronic obstructive pulmonary disease in asymptomatic heavy smokers. Mol Biosyst 10, 5, 1072-1081. https://doi.org/ $10.1039 / \mathrm{c} 3 \mathrm{mb} 70564 \mathrm{a}$.

185. Fu RQ, Hu DP, Hu YB, Hong L, Sun QF, Ding JG (2017), miR-21 promotes $\alpha$-SMA and collagen I expression in hepatic stellate cells via the Smad7 signaling pathway. Mol Med Rep 16, 4, 4327-4333. https://doi.org/10.3892/ mmr.2017.7054.

186. Bitomsky N, Bohm M, Klempnauer KH (2004), Transformation suppressor protein Pdcd4 interferes with JNKmediated phosphorylation of c-Jun and recruitment of the coactivator p300 by c-Jun. Oncogene 23, 45, 7484-7493. https://doi.org/10.1038/sj.onc.1208064.

187. Asangani IA, Rasheed SA, Nikolova DA, Leupold JH, Colburn NH, Post S, Allgayer H (2008), MicroRNA-21 (miR-21) post-transcriptionally downregulates tumor suppressor Pdcd4 and stimulates invasion, intravasation and metastasis in colorectal cancer. Oncogene 27, 15, 2128 2136. https://doi.org/10.1038/sj.onc.1210856.

188. Krichevsky AM, Gabriely G (2009), miR-21: A small multifaceted RNA. J Cell Mol Med 13, 1, 39-53. https://doi.org/ 10.1111/j.1582-4934.2008.00556.x. 
189. Luo M, Tan X, Mu L, Luo Y, Li R, Deng X, Chen N, Ren M, Li Y, Wang L, Wu J, Wan Q (2017), MiRNA-21 mediates the antiangiogenic activity of metformin through targeting PTEN and SMAD7 expression and PI3K/AKT pathway. Sci Rep 7, 43427. https://doi.org/10.1038/srep43427.

190. Yamanaka Y, Tagawa H, Takahashi N, Watanabe A, Guo YM, Iwamoto K, Yamashita J, Saitoh H, Kameoka Y, Shimizu N, Ichinohasama R, Sawada K (2009), Aberrant overexpression of microRNAs activate AKT signaling via down-regulation of tumor suppressors in natural killercell lymphoma/leukemia. Blood 114, 15, 3265-3275. https://doi.org/10.1182/blood-2009-06-222794.

191. Hatley ME, Patrick DM, Garcia MR, Richardson JA, Bassel-Duby R, van Rooij E, Olson EN (2010), Modulation of K-Ras-dependent lung tumorigenesis by MicroRNA-21. Cancer Cell 18, 3, 282-293. https://doi.org/10.1016/j. ccr.2010.08.013.

192. Cilek EE, Ozturk H, Gur Dedeoglu B (2017), Construction of miRNA-miRNA networks revealing the complexity of miRNA-mediated mechanisms in trastuzumab treated breast cancer cell lines. PLoS One 12, 10, e0185558. https://doi.org/10.1371/journal.pone.0185558.

193. Eckner R, Ludlow JW, Lill NL, Oldread E, Arany Z, Modjtahedi N, DeCaprio JA, Livingston DM, Morgan JA (1996), Association of p300 and CBP with simian virus 40 large T antigen. Mol Cell Biol 16, 7, 3454-3464. https://doi. org/10.1128/MCB.16.7.3454.

194. Xiao XS, Cai MY, Chen JW, Guan XY, Kung HF, Zeng YX, Xie D (2011), High expression of p300 in human breast cancer correlates with tumor recurrence and predicts adverse prognosis. Chin J Cancer Res 23, 3, 201-207. https://doi.org/10.1007/s11670-011-0201-5.

195. Smith JL, Freebern WJ, Collins I, De Siervi A, Montano I, Haggerty CM, McNutt MC, Butscher WG, Dzekunova I, Petersen DW, Kawasaki E, Merchant JL, Gardner K (2004), Kinetic profiles of p300 occupancy in vivo predict common features of promoter structure and coactivator recruitment. Proc Natl Acad Sci USA 101, 32, 11554-11559. https://doi.org/10.1073/pnas.0402156101.

196. Kanamaru Y, Nakao A, Tanaka Y (2003), Involvement of p300 in TGF-beta/Smad-pathway-mediated alpha2(I) collagen expression in mouse mesangial cells. Nephron Exp Nephrol 95, 1, e36-e42. https://doi.org/10.1159/ 000073022 .

197. Kassimatis TI, Giannopoulou I, Koumoundourou D, Theodorakopoulou E, Varakis I, Nakopoulou L (2006), Immunohistochemical evaluation of phosphorylated SMAD2/SMAD3 and the co-activator P300 in human glomerulonephritis: Correlation with renal injury. J Cell Mol Med 10, 4, 908-921. https://doi.org/10.2755/ jcmm010.004.05.

198. Kurebayashi J, Otsuki T, Kunisue H, Tanaka K, Yamamoto S, Sonoo H (2000), Expression levels of estrogen receptor-alpha, estrogen receptor-beta, coactivators, and corepressors in breast cancer. Clin Cancer Res 6, 2, 512-518.

199. Karamouzis MV, Konstantinopoulos PA, Papavassiliou AG (2007), Roles of CREB-binding protein (CBP)/p300 in respiratory epithelium tumorigenesis. Cell Res 17, 4, 324332. https://doi.org/10.1038/cr.2007.10.

200. Ishihama K, Yamakawa M, Semba S, Takeda H, Kawata S, Kimura S, Kimura W (2007), Expression of HDAC1 and $\mathrm{CBP} /$ p300 in human colorectal carcinomas. J Clin Pathol 60, 11, 1205-1210. https://doi.org/10.1136/ jcp.2005.029165.

201. Debes JD, Sebo TJ, Lohse CM, Murphy LM, Haugen DA, Tindall DJ (2003), p300 in prostate cancer proliferation and progression. Cancer Res 63, 22, 7638-7640.
202. Borrow J, Stanton VP Jr, Andresen JM, Becher R, Behm FG, Chaganti RS, Civin CI, Disteche C, Dubé I, Frischauf AM, Horsman D, Mitelman F, Volinia S, Watmore AE, Housman DE (1996), The translocation $\mathrm{t}(8 ; 16)(\mathrm{p} 11 ; \mathrm{p} 13)$ of acute myeloid leukaemia fuses a putative acetyltransferase to the CREB-binding protein. Nat Genet 14, 1, 33-41. https://doi.org/10.1038/ng0996-33.

203. Huh JW, Kim HC, Kim SH, Park YA, Cho YB, Yun SH, Lee WY, Chun HK (2013), Prognostic impact of p300 expression in patients with colorectal cancer. J Surg Oncol 108, 6, 374-377. https://doi.org/10.1002/jso.23405.

204. Bordonaro M, Lazarova DL (2015), CREB-binding protein, p300, butyrate, and Wnt signaling in colorectal cancer. World J Gastroenterol 21, 27, 8238-8248. https://doi.org/ 10.3748/wjg.v21.i27.8238.

205. Black AR, Black JD, Azizkhan-Clifford J (2001), Sp1 and krüppel-like factor family of transcription factors in cell growth regulation and cancer. J Cell Physiol 188, 2, 143160. https://doi.org/10.1002/jcp.1111.

206. Beishline K, Azizkhan-Clifford J (2015), Sp1 and the 'hallmarks of cancer'. FEBS J 282, 2, 224-258. https://doi.org/10.1111/febs.13148.

207. Kadonaga JT, Carner KR, Masiarz FR, Tjian R (1987), Isolation of cDNA encoding transcription factor $\mathrm{Sp} 1$ and functional analysis of the DNA binding domain. Cell 51, 6, 1079-1090. https://doi.org/10.1016/0092-8674(87)90594-0.

208. Kriwacki RW, Schultz SC, Steitz TA, Caradonna JP (1992), Sequence-specific recognition of DNA by zinc-finger peptides derived from the transcription factor Sp1. Proc Natl Acad Sci USA 89, 20, 9759-9763.

209. Ito T, Azumano M, Uwatoko C, Itoh K, Kuwahara J (2009), Role of zinc finger structure in nuclear localization of transcription factor Sp1. Biochem Biophys Res Commun 380, 1, 28-32. https://doi.org/10.1016/j.bbrc.2008.12.165.

210. Williams AO, Isaacs RJ, Stowell KM (2007), Sp1 and Sp3 bound at proximal and distal promoter regions. BMC Mol Biol 8, 36. https://doi.org/10.1186/1471-2199-8-36.

211. Guan H, Cai J, Zhang N, Wu J, Yuan J, Li J, Li M (2012), Sp1 is upregulated in human glioma, promotes MMP-2mediated cell invasion and predicts poor clinical outcome. Int J Cancer 130, 3, 593-601. https://doi.org/10.1002/ ijc. 26049 .

212. Chiefari E, Brunetti A, Arturi F, Bidart JM, Russo D, Schlumberger M, Filetti S (2002), Increased expression of AP2 and Sp1 transcription factors in human thyroid tumors: A role in NIS expression regulation? BMC Cancer 2,35 .

213. Wang XB, Peng WQ, Yi ZJ, Zhu SL, Gan QH (2007), Expression and prognostic value of transcriptional factor sp1 in breast cancer. Ai Zheng 26, 9, 996-1000.

214. Hsu TI, Wang MC, Chen SY, Yeh YM, Su WC, Chang WC, Hung JJ (2012), Sp1 expression regulates lung tumor progression. Oncogene 31, 35, 3973-3988. https://doi.org/ 10.1038/onc.2011.568.

215. Wang L, Wei D, Huang S, Peng Z, Le X, Wu TT, Yao J, Ajani J, Xie K (2003), Transcription factor Sp1 expression is a significant predictor of survival in human gastric cancer. Clin Cancer Res 9, 17, 6371-6380.

216. Jiang NY, Woda BA, Banner BF, Whalen GF, Dresser KA, Lu D (2008), Sp1, a new biomarker that identifies a subset of aggressive pancreatic ductal adenocarcinoma. Cancer Epidemiol Biomarkers Prev 17, 7, 1648-1652. https://doi. org/10.1158/1055-9965.EPI-07-2791.

217. Black AR, Jensen D, Lin SY, Azizkhan JC (1999), Growth/cell cycle regulation of Sp1 phosphorylation. J Biol Chem 274, 3, 1207-1215. https://doi.org/10.1074/ jbc.274.3.1207. 
218. Murthy S, Ryan AJ, Carter AB (2012), SP-1 regulation of MMP-9 expression requires Ser586 in the PEST domain. Biochem J 445, 2, 229-236. https://doi.org/10.1042/ BJ20120053.

219. Presser LD, McRae S, Waris G (2013), Activation of TGF$\beta 1$ promoter by hepatitis $\mathrm{C}$ virus-induced $\mathrm{AP}-1$ and $\mathrm{Sp} 1$ : role of TGF- $\beta 1$ in hepatic stellate cell activation and invasion. PLoS One 8, 2, e56367. https://doi.org/10.1371/ journal.pone.0056367.

220. Li R, Xiao J, Qing X, Xing J, Xia Y, Qi J, Liu X, Zhang S, Sheng X, Zhang X, Ji X (2015), Sp1 mediates a therapeutic role of $\mathrm{MiR}-7 \mathrm{a} / \mathrm{b}$ in angiotensin II-Induced cardiac fibrosis via mechanism involving the TGF- $\beta$ and MAPKs pathways in cardiac fibroblasts. PLoS One 10, 4, e0125513. https://doi.org/10.1371/journal.pone.0125513.

221. Liu Y, Liao R, Qiang Z, Zhang C (2017), Pro-inflammatory cytokine-driven PI3K/Akt/Sp1 signalling and $\mathrm{H}_{2} \mathrm{~S}$ production facilitates the pathogenesis of severe acute pancreatitis. Biosci Rep 37, 2, 1-11. https://doi.org/10.1042/ BSR20160483.

222. Yu J, Wei M, Boyd Z, Lehmann EB, Trotta R, Mao H, Liu S, Becknell B, Jaung MS, Jarjoura D (2007), Transcriptional control of human T-BET expression: The role of Sp1. Eur J Immunol 37, 9, 2549-2561. https://doi.org/10.1002/ eji.200737088.

223. Pan MR, Hung WC (2002), Nonsteroidal anti-inflammatory drugs inhibit matrix metalloproteinase-2 via suppression of the ERK/Sp1-mediated transcription. J Biol Chem 277, 36, 32775-32780. https://doi.org/10.1074/jbc.M202334200.

224. Li J, Du S, Sheng X, Liu J, Cen B, Huang F, He Y (2016), MicroRNA-29b inhibits endometrial fibrosis by regulating the Sp1-TGF- $\beta 1 /$ Smad-CTGF axis in a rat model. Reprod Sci 23, 3, 386-394. https://doi.org/10.1177/ 1933719115602768.

225. Yang KL, Chang WT, Hong MY, Hung KC, Chuang CC (2017), Prevention of TGF- $\beta$-induced early liver fibrosis by a maleic acid derivative anti-oxidant through suppression of ROS, inflammation and hepatic stellate cells activation. PLoS One 12, 4, e0174008. https://doi.org/10.1371/journal.pone.0174008.

226. Jiang L, Zhou Y, Xiong M, Fang L, Wen P, Cao H, Yang J, Dai C, He W (2013), Sp1 mediates microRNA-29c-regulated type I collagen production in renal tubular epithelial cells. Exp Cell Res 319, 14, 2254-2265. https://doi.org/10.1016/j. yexcr.2013.06.007.

227. Spurney CF, Sali A, Guerron AD, Iantorno M, Yu Q, Gordish-Dressman H, Rayavarapu S, van der Meulen J, Hoffman EP, Nagaraju K (2017), Losartan decreases cardiac muscle fibrosis and improves cardiac function in dystrophin-deficient mdx mice. J Cardiovasc Pharmacol Ther 16, 1, 87-95. https://doi.org/10.1177/ 1074248410381757.

228. Drews HJ, Yenkoyan K, Lourhmati A, Buadze M, Kabisch D, Verleysdonk S, Petschak S, Beer-Hammer S, Davtyan T, Frey WH 2nd, Gleiter CH, Schwab MDanielyanL (2019), Intranasal losartan decreases perivascular beta amyloid, inflammation, and the decline of neurogenesis in hypertensive rats. Neurotherapeutics. 1-16. https://doi.org/ 10.1007/s13311-019-00723-6.

229. Zhao Y, Cao J, Melamed A, Worley M, Gockley A, Jones D, Nia HT, Zhang Y, Stylianopoulos T, Kumar AS, Mpekris F, Datta M, Sun Y, Wu L, Gao X, Yeku O, Del Carmen MG, Spriggs DR, Jain RK, Xu L (2019), Losartan treatment enhances chemotherapy efficacy and reduces ascites in ovarian cancer models by normalizing the tumor stroma. Proc Natl Acad Sci USA 116, 6, 2210-2219. https://doi. org $/ 10.1073 /$ pnas. 1818357116 .
230. Nishimura N, Kaji K, Kitade M, Aihara Y, Sato S, Seki K, Sawada Y, Takaya H, Okura Y, Kawaratani H, Moriya K, Namisaki T, Mitoro A, Yoshiji H (2018), Acyclic retinoid and angiotensin-II receptor blocker exert a combined protective effect against diethylnitrosamine-induced hepatocarcinogenesis in diabetic OLETF rats. BMC Cancer 18, 1, 1164. https://doi.org/10.1186/s12885-018-5099-6.

231. Coulson R, Liew SH, Connelly AA, Yee NS, Deb S, Kumar B, Vargas AC, O'Toole SA, Parslow AC, Poh A, Putoczki T, Morrow RJ, Alorro M, Lazarus KA, Yeap EFW, Walton KL, Harrison CA, Hannan NJ, George AJ, Clyne CD, Ernst M, Allen AM, Chand AL (2017), The angiotensin receptor blocker. Losartan, inhibits mammary tumor development and progression to invasive carcinoma, Oncotarget 812, 18640-18656. https://doi.org/10.18632/oncotarget.15553.

232. Chua CC, Hamdy RC, Chua BH (1997), Regulation of thrombospondin-1 production by angiotensin II in rat heart endothelial cells. Biochim Biophys Acta 1357, 2, 209-214. PMID: 9223624

233. Chauhan VP, Martin JD, Liu H, Lacorre DA, Jain SR, Kozin SV, Stylianopoulos T, Mousa AS, Han X, Adstamongkonkul P, Popović Z, Huang P, Bawendi MG, Boucher Y, Jain RK (2013), Angiotensin inhibition enhances drug delivery and potentiates chemotherapy by decompressing tumour blood vessels. Nat Commun 4, 2516. https://doi. org $/ 10.1038 /$ ncomms 3516 .

234. Diop-Frimpong B, Chauhan VP, Krane S, Boucher Y, Jain RK (2011), Losartan inhibits collagen I synthesis and improves the distribution and efficacy of nanotherapeutics in tumors. Proc Natl Acad Sci USA 108, 7, 2909-2914. https://doi.org/10.1073/pnas.1018892108.

235. Wang X, Chen X, Huang W, Zhang P, Guo Y, Körner H, Wu H, Wei W (2018), Losartan suppresses the inflammatory response in collagen-induced arthritis by inhibiting the MAPK and NF- $\kappa$ B pathways in B and T cells. Inflammopharmacology, 1-16. https://doi.org/10.1007/s10787018-0545-2.

236. Saikawa S, Kaji K, Nishimura N, Seki K, Sato S, Nakanishi K, Kitagawa K, Kawaratani H, Kitade M, Moriya K, Namisaki T, Mitoro A, Yoshiji H (2018), Angiotensin receptor blockade attenuates cholangiocarcinoma cell growth by inhibiting the oncogenic activity of yes-associated protein. Cancer Lett 434, 120-129. https://doi.org/ 10.1016/j.canlet.2018.07.021.

237. Matsushima-Otsuka S, Fujiwara-Tani R, Sasaki T, Ohmori H, Nakashima C, Kishi S, Nishiguchi Y, Fujii K, Luo Y, Kuniyasu H (2018), Significance of intranuclear angiotensin-II type 2 receptor in oral squamous cell carcinoma. Oncotarget 9, 93, 36561-36574. https://doi.org/10.18632/ oncotarget.26337.

238. Shen H, Gao Q, Ye Q, Yang S, Wu Y, Huang Q, Wang X, Sun Z (2018), Peritumoral implantation of hydrogelcontaining nanoparticles and losartan for enhanced nanoparticle penetration and antitumor effect. Int J Nanomedicine 13, 7409-7426. https://doi.org/10.2147/ IJN.S178585.

239. Murphy JE, et al. (2018), Potentially curative combination of TGF-b1 inhibitor losartan and FOLFIRINOX (FFX) for locally advanced pancreatic cancer (LAPC): R0 resection rates and preliminary survival data from a prospective phase II study. J Clin Oncol 36, 15_Suppl, 4116-4116.

240. Busby J, McMenamin Ú, Spence A, Johnston BT, Hughes C, Cardwell CR (2018), Angiotensin receptor blocker use and gastro-oesophageal cancer survival: A population-based cohort study. Aliment Pharmacol Ther 47, 2, 279-288. https://doi.org/10.1111/apt.14388. 
241. Jia Z, Gao Y, Wang L, Li Q, Zhang J, Le X, Wei D, Yao JC, Chang DZ, Huang S, Xie K (2010), Combined treatment of pancreatic cancer with mithramycin A and tolfenamic acid promotes Sp1 degradation and synergistic antitumor activity. Cancer Res 70, 3, 1111-1119. https://doi.org/10.1158/ 0008-5472.CAN-09-3282.

242. Gao Y, Jia Z, Kong X, Li Q, Chang DZ, Wei D, Le X, Suyun H, Huang S, Wang L, Xie K (2011), Combining betulinic acid and mithramycin A effectively suppresses pancreatic cancer by inhibiting proliferation, invasion and angiogenesis. Cancer Res 71, 15, 5182-5193. https://doi.org/10.1158/ 0008-5472.CAN-10-2016.

243. Li JM, Datto MB, Shen X, Hu PP, Yu Y, Wang XF (1998), Sp1, but not Sp3, functions to mediate promoter activation by TGF-beta through canonical Sp1 binding sites. Nucleic Acids Res 26, 10, 2449-2456.

244. Hu J, Shan Z, Hu K, Ren F, Zhang W, Han M, Li Y, Feng K, Lei L, Feng Y (2016), miRNA-223 inhibits epithelialmesenchymal transition in gastric carcinoma cells via Sp1. Int J Oncol 49, 1, 325-335. https://doi.org/10.3892/ ijo.2016.3533.

245. Hsieh MJ, Chen JC, Yang WE, Chien SY, Chen MK, Lo YS, Hsi YT, Chuang YC, Lin CC, Yang SF (2017), Dehydroandrographolide inhibits oral cancer cell migration and invasion through NF- $\kappa$ B-, AP-1-, and SP-1-modulated matrix metalloproteinase-2 inhibition. Biochem Pharmacol 130, 10-20. https://doi.org/10.1016/j.bcp.2017.01.011.

246. Eferl R, Hasselblatt P, Rath M, Popper H, Zenz R, Komnenovic V, Idarraga MH, Kenner L, Wagner EF (2008), Development of pulmonary fibrosis through a pathway involving the transcription factor Fra-2/AP-1. Proc Natl Acad Sci USA 105, 30, 10525-10530. https://doi. org $/ 10.1073 /$ pnas.0801414105.

247. Angel P, Szabowski A, Schorpp-Kistner M (2001), Function and regulation of AP-1 subunits in skin physiology and pathology. Oncogene 20, 19, 2413-2423. https://doi.org/ 10.1038 /sj.onc. 1204380 .

248. Kim JM, Jung HY, Lee JY, Youn J, Lee CH, Kim KH (2005), Mitogen-activated protein kinase and activator protein-1 dependent signals are essential for Bacteroides fragilis enterotoxin-induced enteritis. Eur J Immunol 35, 9, 2648-2657. https://doi.org/10.1002/eji.200526321.

249. Jayakar SK, Loudig O, Brandwein-Gensler M, Kim RS, Ow TJ, Ustun B, Harris TM, Prystowsky MB, Childs G, Segall JE, Belbin TJ (2017), Apolipoprotein E promotes invasion in oral squamous cell carcinoma. Am J Pathol 187, 10, 2259-2272. https://doi.org/10.1016/j.ajpath.2017.06.016.

250. Prusty BK, Das BC (2005), Constitutive activation of transcription factor AP-1 in cervical cancer and suppression of human papillomavirus (HPV) transcription and AP-1 activity in HeLa cells by curcumin. Int J Cancer 113, 6, 951960. https://doi.org/10.1002/ijc.20668.

251. Tyagi A, Vishnoi K, Kaur H, Srivastava Y, Roy BG, Das BC, Bharti AC (2017), Cervical cancer stem cells manifest radioresistance: Association with upregulated AP-1 activity. Sci Rep 7, 1, 4781. https://doi.org/10.1038/s41598-01705162-x.

252. Fichtner-Feigl S, Strober W, Kawakami K, Puri RK, Kitani A (2006), IL-13 signaling through the IL-13alpha2 receptor is involved in induction of TGF-beta1 production and fibrosis. Nat Med 12, 1, 99-106. https://doi.org/10.1038/ nm1332.

253. Park CH, Kim DH, Park MH, Kim MK, Kim ND, Kim CM, Tanaka T, Yokozawa T, Chung HY, Moon HR (2014), Chinese prescription Kangen-karyu and Salviae miltiorrhizae Radix improve age-related oxidative stress and inflammatory response through the PI3K/Akt or MAPK pathways. Am J Chin Med 42, 4, 987-1005. https://doi. org/10.1142/S0192415X14500621.

254. Kim JM, Noh EM, Song HK, Lee M, Lee SH, Park SH, Ahn CK, Lee GS, Byun EB, Jang BS, Kwon KB, Lee YR (2017), Salvia miltiorrhiza extract inhibits TPA-induced MMP-9 expression and invasion through the MAPK/AP-1 signaling pathway in human breast cancer MCF-7 cells. Oncol Lett 14, 3, 3594-3600. https://doi.org/10.3892/ol.2017.6638.

255. Kajanne R, Miettinen P, Mehlem A, Leivonen SK, Birrer M, Foschi M, Kähäri VM, Leppä S (2007), EGF-R regulates MMP function in fibroblasts through MAPK and AP-1 pathways. J Cell Physiol 212, 2, 489-497. https://doi.org/ $10.1002 /$ jcp. 21041.

256. Lin CW, Hou WC, Shen SC, Juan SH, Ko CH, Wang LM, Chen YC (2008), Quercetin inhibition of tumor invasion via suppressing PKC delta/ERK/AP-1-dependent matrix metalloproteinase- 9 activation in breast carcinoma cells. Carcinogenesis 29, 9, 1807-1815. https://doi.org/ $10.1093 /$ carcin/bgn162.

257. Ghatak S, Markwald RR, Hascall VC, Dowling W, Lottes RG, Baatz JE, Beeson G, Beeson CC, Perrella MA, Thannickal VJ, Misra S (2017), Transforming growth factor $\beta 1$ (TGF $\beta 1$ ) regulates CD44V6 expression and activity through extracellular signal-regulated kinase (ERK)-induced EGR1 in pulmonary fibrogenic fibroblasts. J Biol Chem 292, 25, 10465-10489. https://doi.org/ 10.1074/jbc.M116.752451.

258. Guinea-Viniegra J, Jiménez M, Schonthaler HB, Navarro R, Delgado Y, Concha-Garzón MJ, Tschachler E, Obad S, Daudén E, Wagner EF (2014), Targeting miR-21 to treat psoriasis. Sci Transl Med 6, 225, 225. https://doi.org/ 10.1126/scitranslmed.3008089.

259. Talotta F, Cimmino A, Matarazzo MR, Casalino L, De Vita G, D'Esposito M, Di Lauro R, Verde P (2009), An autoregulatory loop mediated by miR-21 and PDCD4 controls the AP-1 activity in RAS transformation. Oncogene 28, 1, 73-84. https://doi.org/10.1038/onc.2008.370.

260. Misawa A, Katayama R, Koike S, Tomida A, Watanabe T, Fujita N (2010), AP-1-dependent miR-21 expression contributes to chemoresistance in cancer stem cell-like SP cells. Oncol Res 19, 1, 23-33.

261. Suh J, Jeon YJ, Kim HM, Kang JS, Kaminski NE, Yang KH (2002), Aryl hydrocarbon receptor-dependent inhibition of AP-1 activity by 2,3,7,8-tetrachlorodibenzo-p-dioxin in activated B cells. Toxicol Appl Pharmacol 181, 2, 116123. https://doi.org/10.1006/taap.2002.9403.

262. Øvrevik J, Låg M, Lecureur V, Gilot D, Lagadic-Gossmann D, Refsnes M, Schwarze PE, Skuland T, Becher R, Holme JA (2014), AhR and Arnt differentially regulate NF- $\kappa \mathrm{B}$ signaling and chemokine responses in human bronchial epithelial cells. Cell Commun Signal 12, 48, 1-7. https://doi.org/10.1186/s12964-014-0048-8.

263. Poland A, Glover E (1973), 2,3,7,8-Tetrachlorodibenzo-pdioxin: a potent inducer of -aminolevulinic acid synthetase. Science 179, 4072, 476-477. PMID: 4705342.

264. Poland A, Glover E (1973), Chlorinated dibenzo-p-dioxins: potent inducers of delta-aminolevulinic acid synthetase and aryl hydrocarbon hydroxylase. II. A study of the structureactivity relationship. Mol Pharmacol 9, 6, 736-747. PMID: 4762634.

265. Poland A, Glover E, Kende AS (1976), Stereospecific, high affinity binding of 2,3,7,8-tetrachlorodibenzo-p-dioxin by hepatic cytosol. Evidence that the binding species is receptor for induction of aryl hydrocarbon hydroxylase. J Biol Chem 251, 16, 4936-4946. PMID: 956169.

266. Okey AB, Bondy GP, Mason ME, Kahl GF, Eisen HJ, Guenthner TM, Nebert DW (1979), Regulatory gene 
product of the Ah locus. Characterization of the cytosolic inducer-receptor complex and evidence for its nuclear translocation. J Biol Chem 254, 22, 11636-11648. PMID: 500663.

267. Okey AB, Bondy GP, Mason ME, Nebert DW, ForsterGibson CJ, Muncan J, Dufresne MJ (1980), Temperaturedependent cytosol-to-nucleus translocation of the Ah receptor for 2,3,7,8-tetrachlorodibenzo-p-dioxin in continuous cell culture lines. J Biol Chem 255, 23, 11415-11422. PMID: 6254968 .

268. Hoffman EC, Reyes H, Chu FF, Sander F, Conley LH, Brooks BA, Hankinson O (1991), Cloning of a factor required for activity of the Ah (dioxin) receptor. Science 252, 5008, 954-958. PMID: 1852076.

269. Trombino AF, Near RI, Matulka RA, Yang S, Hafer LJ, Toselli PA, Kim DW, Rogers AE, Sonenshein GE, Sherr DH (2000), Expression of the aryl hydrocarbon receptor/transcription factor (AhR) and AhR-regulated CYP1 gene transcripts in a rat model of mammary tumorigenesis. Breast Cancer Res Treat 63, 2, 117-131. PMID: 11097088.

270. Schlezinger JJ, Liu D, Farago M, Seldin DC, Belguise K, Sonenshein GE, Sherr DH (2006), A role for the aryl hydrocarbon receptor in mammary gland tumorigenesis. Biol Chem 387, 9, 1175-1187. https://doi.org/10.1515/ BC.2006.145.

271. Fenton SE, Reed C, Newbold RR (2012), Perinatal environmental exposures affect mammary development, function, and cancer risk in adulthood. Annu Rev Pharmacol Toxicol 52, 455-479. https://doi.org/10.1146/annurevpharmtox-010611-134659.

272. Vacher S, Castagnet P, Chemlali W, Lallemand F, Meseure D, Pocard M, Bieche I, Perrot-Applanat M (2018), High AHR expression in breast tumors correlates with expression of genes from several signaling pathways namely inflammation and endogenous tryptophan metabolism. PLoS One 13, 1, e0190619. https://doi.org/10.1371/journal. pone.0190619.

273. Yang X, Liu D, Murray TJ, Mitchell GC, Hesterman EV, Karchner SI, Merson RR, Hahn ME, Sherr DH (2005), The aryl hydrocarbon receptor constitutively represses c-myc transcription in human mammary tumor cells. Oncogene 24, 53, 7869-7881. https://doi.org/10.1038/sj.onc.1208938.

274. Modjtahedi N, Lavialle C, Poupon MF, Landin RM, Cassingena R, Monier R, Brison O (1985), Increased level of amplification of the c-myc oncogene in tumors induced in nude mice by a human breast carcinoma cell line. Cancer Res 45, 9, 4372-4379. PMID: 4028021.

275. Whittaker JL, Walker RA, Varley JM (1986), Differential expression of cellular oncogenes in benign and malignant human breast tissue. Int J Cancer 38, 5, 651-655. PMID: 3770994.

276. Pavelic ZP, Steele P, Presler HD (1991), Evaluation of cmyc proto-oncogene in primary human breast carcinomas. Anticancer Res 11, 4, 1421-1427. PMID: 1660688.

277. Berns EM, Klijn JG, van Putten WL, van Staveren IL, Portengen H, Foekens JA (1992), c-myc amplification is a better prognostic factor than HER2/neu amplification in primary breast cancer. Cancer Res 52, 5, 1107-1113. PMID: 1737370 .

278. Borg A, Baldetorp B, Ferno M, Olsson H, Sigurdsson H (1992), c-myc amplification is an independent prognostic factor in postmenopausal breast cancer. Int J Cancer 51, 5, 687-691. PMID: 1612775.

279. Marcu KB, Harris LJ, Stanton LW, Erikson J, Watt R, Croce CM (1983), Transcriptionally active c-myc oncogene is contained within NIARD, a DNA sequence associated with chromosome translocations in B-cell neoplasia. Proc Natl Acad Sci USA 80, 2, 519-523. PMCID: PMC393410.

280. Mushinski JF, Bauer SR, Potter M, Reddy EP (1983), Increased expression of myc-related oncogene mRNA characterizes most BALB/c plasmacytomas induced by pristane or Abelson murine leukemia virus. Proc Natl Acad Sci USA 80, 4, 1073-1077. PMCID: PMC393530.

281. Roy-Burman P, Devi BG, Parker JW (1983), Differential expression of c-erbB, c-myc and c-myb oncogene loci in human lymphomas and leukemias. Int J Cancer 32, 2, 185 191. PMID: 6603429.

282. Little CD, Nau MM, Carney DN, Gazdar AF, Minna JD (1983), Amplification and expression of the c-myc oncogene in human lung cancer cell lines. Nature 306, 5939, 194-196. PMID: 6646201

283. Griffin CA, Baylin SB (1985), Expression of the c-myb oncogene in human small cell lung carcinoma. Cancer Res $45,1,272-275$.

284. Kohl NE, Gee CE, Alt FW (1984), Activated expression of the N-myc gene in human neuroblastomas and related tumors. Science 226, 4680, 1335-1337. PMID: 6505694.

285. Makino R, Hayashi K, Sato S, Sugimura T (1984), Expressions of the c-Ha-ras and c-myc genes in rat liver tumors. Biochem Biophys Res Commun 119, 3, 1092-1102. PMID: 6712668

286. Yaswen P, Goyette M, Shank PR, Fausto N (1985), Expression of c-Ki-ras, c-Ha-ras, and c-myc in specific cell types during hepatocarcinogenesis. Mol Cell Biol 5, 4, 780786. PMID: 2581126.

287. Sikora K, Evan G, Stewart J, Watson JV (1985), Detection of the c-myc oncogene product in testicular cancer. Br J Cancer 52, 2, 171-176.

288. Stewart J, Evan G, Watson J, Sikora K (1986), Detection of the c-myc oncogene product in colonic polyps and carcinomas. Br J Cancer 53, 1, 1-6. PMID: 3511934.

289. Sikora K, Chan S, Evan G, Gabra H, Markham N, Stewart J, Watson J (1987), c-myc oncogene expression in colorectal cancer. Cancer 59, 7, 1289-1295.

290. Sovak MA, Bellas RE, Kim DW, Zanieski GJ, Rogers AE, Traish AM, Sonenshein GE (1997), Aberrant nuclear factor-kappaB/Rel expression and the pathogenesis of breast cancer. J Clin Invest 100, 12, 2952-2960.

291. Tian Y, Ke S, Denison MS, Rabson AB, Gallo MA (1999), Ah receptor and NF-kappaB interactions, a potential mechanism for dioxin toxicity. J Biol Chem 274, 1, 510515. PMID: 9867872

292. Kim DW, Gazourian L, Quadri SA, Romieu-Mourez R, Sherr DH, Sonenshein GE (2000), The RelA NF-kappaB subunit and the aryl hydrocarbon receptor (AhR) cooperate to transactivate the c-myc promoter in mammary cells. Oncogene 19, 48, 5498-5506. https://doi.org/10.1038/sj. onc. 1203945

293. Stobbe-Maicherski N, Wolff S, Wolff C, Abel J, Sydlik U, Frauenstein K, Haarmann-Stemmann T (2013), The interleukin-6-type cytokine oncostatin $\mathrm{M}$ induces aryl hydrocarbon receptor expression in a STAT3-dependent manner in human HepG2 hepatoma cells. FEBS J 280, 24, 6681-6690. https://doi.org/10.1111/febs.12571.

294. DiNatale BC, Schroeder JC, Francey LJ, Kusnadi A, Perdew GH (2010), Mechanistic insights into the events that lead to synergistic induction of interleukin 6 transcription upon activation of the aryl hydrocarbon receptor and inflammatory signaling. J Biol Chem 285, 32, 24388-24397. https://doi.org/10.1074/jbc.M110.118570.

295. Nguyen CH, Brenner S, Huttary N, Atanasov AG, Dirsch VM, Chatuphonprasert W, Holzner S, Stadler S, Riha J, Krieger S, de Martin R, Bago-Horvath Z, Krupitza G, Jäger 
W (2016), AHR/CYP1A1 interplay triggers lymphatic barrier breaching in breast cancer spheroids by inducing 12(S)-HETE synthesis. Hum Mol Genet 25, 22, 5006-5016. https://doi.org/10.1093/hmg/ddw329.

296. Metidji A, Omenetti S, Crotta S, Li Y, Nye E, Ross E, Li V, Maradana MR, Schiering C, Stockinger B (2018), The environmental sensor AHR protects from inflammatory damage by maintaining intestinal stem cell homeostasis and barrier integrity. Immunity 49, 2, 353-362.e5. https://doi. org/10.1016/j.immuni.2018.07.010.

297. Kawajiri K, Fujii-Kuriyama Y (2017), The aryl hydrocarbon receptor: A multifunctional chemical sensor for host defense and homeostatic maintenance. Exp Anim 66, 2, 7589. https://doi.org/10.1538/expanim.16-0092.

298. Vogel CF, Sciullo E, Matsumura F (2004), Activation of inflammatory mediators and potential role of ah-receptor ligands in foam cell formation. Cardiovasc Toxicol 4, 4, 363-373. PMID: 15531779.

299. Pierre S, Chevallier A, Teixeira-Clerc F, Ambolet-Camoit A, Bui LC, Bats AS, Fournet JC, Fernandez-Salguero P, Aggerbeck M, Lotersztajn S, Barouki R, Coumoul X (2014), Aryl hydrocarbon receptor-dependent induction of liver fibrosis by dioxin. Toxicol Sci 137, 1, 114-124. https://doi. org/10.1093/toxsci/kft236.

300. Harrill JA, Layko D, Nyska A, Hukkanen RR, Manno RA, Grassetti A, Lawson M, Martin G, Budinsky RA, Rowlands JC, Thomas RS (2016), Aryl hydrocarbon receptor knockout rats are insensitive to the pathological effects of repeated oral exposure to 2,3,7,8-tetrachlorodibenzo-pdioxin. J Appl Toxicol 36, 6, 802-814. https://doi.org/ 10.1002/jat.3211.

301. Harrill JA, Parks BB, Wauthier E, Rowlands JC, Reid LM, Thomas RS (2015), Lineage-dependent effects of aryl hydrocarbon receptor agonists contribute to liver tumorigenesis. Hepatology 61, 2, 548-560. https://doi.org/ 10.1002/hep.27547.

302. Gao Z, Bu Y, Liu X, Wang X, Zhang G, Wang E, Ding S, Liu Y, Shi R, Li Q, Fu J, Yu Z (2016), TCDD promoted EMT of hFPECs via AhR, which involved the activation of EGFR/ERK signaling. Toxicol Appl Pharmacol 298, 48-55. https://doi.org/10.1016/j.taap.2016.03.005.

303. Opitz CA, Litzenburger UM, Sahm F, Ott M, Tritschler I, Trump S, Schumacher T, Jestaedt L, Schrenk D, Weller M, Jugold M, Guillemin GJ, Miller CL, Lutz C, Radlwimmer B, Lehmann I, von Deimling A, Wick W, Platten M (2011), An endogenous tumour-promoting ligand of the human aryl hydrocarbon receptor. Nature 478, 7368, 197-203. https://doi.org/10.1038/nature10491.

304. Gramatzki D, Pantazis G, Schittenhelm J, Tabatabai G, Köhle C, Wick W, Schwarz M, Weller M, Tritschler I (2009), Aryl hydrocarbon receptor inhibition downregulates the TGF-beta/Smad pathway in human glioblastoma cells. Oncogene 28, 28, 2593-2605. https://doi.org/10.1038/ onc. 2009.

305. Löb S, Königsrainer A, Zieker D, Brücher BL, Rammensee HG, Opelz G, Terness P (2009), IDO1 and IDO2 are expressed in human tumors: Levo- but not dextro-1-methyl tryptophan inhibits tryptophan catabolism. Cancer Immunol Immunother 58, 1, 153-157. https://doi.org/10.1007/ s00262-008-0513-6.

306. Alahdal M, Xing Y, Tang T, Liang J (2018), 1-methyl-Dtryptophan reduces tumor CD133+ cells, Wnt $/ \beta$-catenin and NF- $\kappa \beta$ p65 while enhances lymphocytes NF- $\kappa \beta 2$, STAT3, and STAT4 pathways in murine pancreatic adenocarcinoma. Sci Rep 8, 1, 9869. https://doi.org/10.1038/ s41598-018-28238-8.
307. Lewis HC, Chinnadurai R, Bosinger SE, Galipeau J (2017), The IDO inhibitor 1-methyl tryptophan activates the aryl hydrocarbon receptor response in mesenchymal stromal cells. Oncotarget 8, 54, 91914-91927. https://doi.org/ 10.18632 /oncotarget.20166.

308. Murphy KA, Villano CM, Dorn R, White LA (2004), Interaction between the aryl hydrocarbon receptor and retinoic acid pathways increases matrix metalloproteinase-1 expression in keratinocytes. J Biol Chem 279, 24, 2528425293.

309. Haque M, Francis J, Sehgal I (2005), Aryl hydrocarbon exposure induces expression of MMP-9 in human prostate cancer cell lines. Cancer Lett 225, 1, 159-166. https://doi. org/10.1016/j.canlet.2004.11.043.

310. Peng TL, Chen J, Mao W, Song X, Chen MH (2009), Aryl hydrocarbon receptor pathway activation enhances gastric cancer cell invasiveness likely through a c-Jun-dependent induction of matrix metalloproteinase-9. BMC Cell Biol 10, 27. https://doi.org/10.1186/1471-2121-10-27.

311. Villano CM, Murphy KA, Akintobi A, White LA (2006), 2,3,7,8-tetrachlorodibenzo-p-dioxin (TCDD) induces matrix metalloproteinase (MMP) expression and invasion in A2058 melanoma cells. Toxicol Appl Pharmacol 210, 3, 212-224.

312. Wei Y, Zhao L, He W, Yang J, Geng C, Chen Y, Liu T, Chen H, Li Y (2016), Benzo[alpyrene promotes gastric cancer cell proliferation and metastasis likely through the Aryl hydrocarbon receptor and ERK-dependent induction of MMP9 and c-myc. Int J Oncol 49, 5, 2055-2063. https://doi.org/10.3892/ijo.2016.3674.

313. Yin XF, Chen J, Mao W, Wang YH, Chen MH (2013), Downregulation of aryl hydrocarbon receptor expression decreases gastric cancer cell growth and invasion. Oncol Rep 30, 1, 364-370. https://doi.org/10.3892/or.2013.2410.

314. Fujisawa-Sehara A, Yamane M, Fujii-Kuriyama Y (1988), A DNA-binding factor specific for xenobiotic responsive elements of P-450c gene exists as a cryptic form in cytoplasm: its possible translocation to nucleus. Proc Natl Acad Sci USA 85, 16, 5859-5863. PMCID: PMC281864.

315. Whitlock JP Jr (1999), Induction of cytochrome P4501A1. Annu Rev Pharmacol Toxicol 39, 103-125. https://doi.org/ 10.1146/annurev.pharmtox.39.1.103.

316. Legraverend C, Hannah RR, Eisen HJ, Owens IS, Nebert DW, Hankinson O (1982), Regulatory gene product of the Ah locus. Characterization of receptor mutants among mouse hepatoma clones. J Biol Chem 257, 11, 6402-6407.

317. Okey AB (2007), An aryl hydrocarbon receptor odyssey to the shores of toxicology: The Deichmann Lecture, International Congress of Toxicology-XI. Toxicol Sci 98, 1, 5-38. https://doi.org/10.1093/toxsci/kfm096.

318. Shimizu Y, Nakatsuru Y, Ichinose M, Takahashi Y, Kume H, Mimura J, Fujii-Kuriyama Y, Ishikawa T (2000), Benzo [a]pyrene carcinogenicity is lost in mice lacking the aryl hydrocarbon receptor. Proc Natl Acad Sci USA 97, 2, 779-782. PMCID: PMC15407.

319. Nebert DW, Dalton TP, Okey AB, Gonzalez FJ (2004), Role of aryl hydrocarbon receptor-mediated induction of the CYP1 enzymes in environmental toxicity and cancer. J Biol Chem 279, 23, 23847-23850. https://doi.org/10.1074/jbc. R400004200.

320. Brücher BLDM, Jamall IS (2016), Somatic mutation theoryWhy it's wrong for most cancers. Cell Physiol Biochem 38, 5, 1663-1680. https://doi.org/10.1159/000443106.

321. Takeda T, Komiya Y, Koga T, Ishida T, Ishii Y, Kikuta Y, Nakaya M, Kurose H, Yokomizo T, Shimizu T, Uchi H, Furue M, Yamada H (2017), Dioxin-induced increase in leukotriene B4 biosynthesis through the aryl hydrocarbon 
receptor and its relevance to hepatotoxicity owing to neutrophil infiltration. J Biol Chem 292, 25, 10586-10599. https://doi.org/10.1074/jbc.M116.764332.

322. Su HH, Lin HT, Suen JL, Sheu CC, Yokoyama KK, Huang SK, Cheng CM (2016), Aryl hydrocarbon receptor-ligand axis mediates pulmonary fibroblast migration and differentiation through increased arachidonic acid metabolism. Toxicology 370, 116-126. https://doi.org/10.1016/ j.tox.2016.09.019.

323. Chiappini F, Bastón JI, Vaccarezza A, Singla JJ, Pontillo C, Miret N, Farina M, Meresman G, Randi A (2016), Enhanced cyclooxygenase-2 expression levels and metalloproteinase 2 and 9 activation by Hexachlorobenzene in human endometrial stromal cells. Biochem Pharmacol 109, 91-104. https://doi.org/10.1016/j.bcp.2016.03.024.

324. de Tomaso Portaz AC, Caimi GR, Sánchez M, Chiappini F, Randi AS, Kleiman de Pisarev DL, Alvarez L (2015), Hexachlorobenzene induces cell proliferation, and aryl hydrocarbon receptor expression (AhR) in rat liver preneoplastic foci, and in the human hepatoma cell line HepG2. AhR is a mediator of ERK1/2 signaling, and cell cycle regulation in HCB-treated HepG2 cells. Toxicology 336, 3647. https://doi.org/10.1016/j.tox.2015.07.013.

325. Díaz-Díaz CJ, Ronnekleiv-Kelly SM, Nukaya M, Geiger PG, Balbo S, Dator R, Megna BW, Carney PR, Bradfield CA, Kennedy GD (2016), The aryl hydrocarbon receptor is a repressor of inflammation-associated colorectal tumorigenesis in mouse. Ann Surg 264, 3, 429-436. https://doi.org/ 10.1097/SLA.0000000000001874.

326. Jönsson ME, Franks DG, Woodin BR, Jenny MJ, Garrick RA, Behrendt L, Hahn ME, Stegeman JJ (2009), The tryptophan photoproduct 6-formylindolo[3,2-b]carbazole (FICZ) binds multiple AHRs and induces multiple CYP1 genes via AHR2 in zebrafish. Chem Biol Interact 181, 3, 447-454. https://doi.org/10.1016/j.cbi.2009.07.003.

327. Ji T, Xu C, Sun L, Yu M, Peng K, Qiu Y, Xiao W, Yang H (2015), Aryl hydrocarbon receptor activation down-regulates IL-7 and reduces inflammation in a mouse model of DSS-induced colitis. Dig Dis Sci 60, 7, 1958-1966. https://doi.org/10.1007/s10620-015-3632-x.

328. Chen JY, Li CF, Kuo CC, Tsai KK, Hou MF, Hung WC (2014), Cancer/stroma interplay via cyclooxygenase-2 and indoleamine 2,3-dioxygenase promotes breast cancer progression. Breast Cancer Res 16, 4, 410. https://doi.org/ 10.1186/s13058-014-0410-1.

329. Hanieh H, Mohafez O, Hairul-Islam VI, Alzahrani A, Bani Ismail M, Thirugnanasambantham K (2016), Novel aryl hydrocarbon receptor agonist suppresses migration and invasion of breast cancer cells. PLoS One 11, 12, e0167650. https://doi.org/10.1371/journal.pone.0167650.

330. Alzahrani AM, Hanieh H, Ibrahim HM, Mohafez O, Shehata T, Bani Ismail M, Alfwuaires M (2017), Enhancing miR-132 expression by aryl hydrocarbon receptor attenuates tumorigenesis associated with chronic colitis. Int Immunopharmacol 52, 342-351. https://doi.org/10.1016/j. intimp.2017.09.015.

331. Fueldner C, Kohlschmidt J, Riemschneider S, Schulze F, Zoldan K, Esser C, Hauschildt S, Lehmann J (2018), Benzo (a)pyrene attenuates the pattern-recognition-receptor induced proinflammatory phenotype of murine macrophages by inducing IL-10 expression in an aryl hydrocarbon receptor-dependent manner. Toxicology 409, 80-90. https://doi.org/10.1016/j.tox.2018.07.011.

332. Xue J, Zhao Q, Sharma V, Nguyen LP, Lee YN, Pham KL, Edderkaoui M, Pandol SJ, Park W, Habtezion A (2016), Aryl Hydrocarbon Receptor Ligands in Cigarette Smoke
Induce Production of Interleukin-22 to Promote Pancreatic Fibrosis in Models of Chronic Pancreatitis. Gastroenterology 151, 6, 1206-1217. https://doi.org/10.1053/ j.gastro.2016.09.064.

333. Fader KA, Nault R, Kirby MP, Markous G, Matthews J, Zacharewski TR (2017), Convergence of hepcidin deficiency, systemic iron overloading, heme accumulation, and REV-ERB $\alpha / \beta$ activation in aryl hydrocarbon receptorelicited hepatotoxicity. Toxicol Appl Pharmacol 321, 1-17. https://doi.org/10.1016/j.taap.2017.02.006.

334. Duan Z, Li Y, Li L (2018), Promoting epithelial-tomesenchymal transition by D-kynurenine via activating aryl hydrocarbon receptor. Mol Cell Biochem 448, 1-2, 165-173. https://doi.org/10.1007/s11010-018-3323-y.

335. Song L, Guo L, Li Z (2017), Molecular mechanisms of 3,3'4,4',5-pentachlorobiphenyl-induced epithelial-mesenchymal transition in human hepatocellular carcinoma cells. Toxicol Appl Pharmacol 322, 75-88. https://doi.org/ 10.1016/j.taap.2017.03.003.

336. Litzenburger UM, Opitz CA, Sahm F, Rauschenbach KJ, Trump S, Winter M, Ott M, Ochs K, Lutz C, Liu X, Anastasov N, Lehmann I, Höfer T, von Deimling A, Wick W, Platten M (2014), Constitutive IDO expression in human cancer is sustained by an autocrine signaling loop involving IL-6, STAT3 and the AHR. Oncotarget 5, 4, 1038-1051. https://doi.org/10.18632/ oncotarget.1637.

337. Gao S, Li S, Duan X, Gu Z, Ma Z, Yuan X, Feng X, Wang H (2017), Inhibition of glycogen synthase kinase 3 beta (GSK3 $\beta$ ) suppresses the progression of esophageal squamous cell carcinoma by modifying STAT3 activity. Mol Carcinog 56, 10, 2301-2316. https://doi.org/10.1002/ mc.22685.

338. Li CH, Liu CW, Tsai CH, Peng YJ, Yang YH, Liao PL, Lee CC, Cheng YW, Kang JJ (2017), Cytoplasmic aryl hydrocarbon receptor regulates glycogen synthase kinase 3 beta, accelerates vimentin degradation, and suppresses epithelialmesenchymal transition in non-small cell lung cancer cells. Arch Toxicol 91, 5, 2165-2178. https://doi.org/10.1007/ s00204-016-1870-0.

339. Santiago-Josefat B, Mulero-Navarro S, Dallas SL, Fernandez-Salguero PM (2004), Overexpression of latent transforming growth factor-beta binding protein 1 (LTBP-1) in dioxin receptor-null mouse embryo fibroblasts. J Cell Sci 117, 849-859.

340. Chang X, Fan Y, Karyala S, Schwemberger S, Tomlinson CR, Sartor MA, Puga A (2007), Ligand-independent regulation of transforming growth factor beta1 expression and cell cycle progression by the aryl hydrocarbon receptor. Mol Cell Biol 27, 17, 6127-6139. https://doi.org/10.1128/ MCB.00323-07.

341. Belancio VP, Roy-Engel AM, Deininger PL (2010), All y'all need to know 'bout retroelements in cancer. Semin Cancer Biol 20, 4, 200-210. https://doi.org/10.1016/j.semcancer. 2010.06.001.

342. Beck CR, Garcia-Perez JL, Badge RM, Moran JV (2011), LINE-1 elements in structural variation and disease. Annu Rev Genom Hum Genet 12, 187-215. https://doi.org/ 10.1146/annurev-genom-082509-141802.

343. Rodić N, Burns KH (2013), Long interspersed element-1 (LINE-1): Passenger or driver in human neoplasms? PLoS Genet 9, 3, e1003402. https://doi.org/10.1371/journal. pgen.1003402.

344. Ostertag EM, Kazazian HH Jr (2001), Biology of mammalian L1 retrotransposons. Annu Rev Genet 35, 501-538. https://doi.org/10.1146/annurev.genet.35.102401.091032. 
345. Schulz WA (2006), L1 retrotransposons in human cancers. J Biomed Biotechnol 2006, 1, 83672. https://doi.org/ 10.1155/JBB/2006/83672.

346. Teneng I, Stribinskis V, Ramos KS (2007), Context-specific regulation of LINE-1. Genes Cells 12, 10, 1101-1110. https://doi.org/10.1111/j.1365-2443.2007.01117.x.

347. He ZM, Li J, Hwa YL, Brost B, Fang Q, Jiang SW (2014), Transition of LINE-1 DNA methylation status and altered expression in first and third trimester placentas. PLoS One $9, \quad 5, \quad$ e96994. https://doi.org/10.1371/journal. pone.0096994.

348. Marques-Rocha JL, Milagro FI, Mansego ML, Mourão DM, Martínez JA, Bressan J (2016), LINE-1 methylation is positively associated with healthier lifestyle but inversely related to body fat mass in healthy young individuals. Epigenetics 11, 1, 49-60. https://doi.org/10.1080/ 15592294.2015.1135286.

349. Gogna P, O'Sullivan DE, King WD (2018), The effect of inflammation-related lifestyle exposures and interactions with gene variants on long interspersed nuclear element-1 DNA methylation. Epigenomics 10, 6, 785-796. https://doi. org/10.2217/epi-2017-0164.

350. Stribinskis V, Ramos KS (2006), Activation of human long interspersed nuclear element 1 retrotransposition by benzo (a)pyrene, an ubiquitous environmental carcinogen. Cancer Res 66, 5, 2616-2620. https://doi.org/10.1158/0008-5472. CAN-05-3478.

351. Bojang P Jr, Roberts RA, Anderton MJ, Ramos KS (2013), Reprogramming of the HepG2 genome by long interspersed nuclear element-1. Mol Oncol 7, 4, 812-825. https://doi. org/10.1016/j.molonc.2013.04.003.

352. Baptista NB, Portinho D, Casarin RC, Vale HF, Casati MZ, De Souza AP, Andia DC (2014), DNA methylation levels of SOCS1 and LINE-1 in oral epithelial cells from aggressive periodontitis patients. Arch Oral Biol 59, 7, 670-678. https://doi.org/10.1016/j.archoralbio.2014.03.015.

353. Maugeri A, Barchitta M, Mazzone MG, Giuliano F, Basile G, Agodi A (2018), Resveratrol modulates SIRT1 and DNMT functions and restores LINE-1 methylation levels in ARPE-19 cells under oxidative stress and inflammation. Int J Mol Sci 19, 7. pii: E2118. https://doi.org/10.3390/ ijms19072118.

354. Andia DC, Planello AC, Portinho D, da Silva RA, Salmon CR, Sallum EA, Junior FH, de Souza AP (2015), DNA methylation analysis of SOCS1, SOCS3, and LINE-1 in microdissected gingival tissue. Clin Oral Invest 19, 9, 23372344. https://doi.org/10.1007/s00784-015-1460-1.

355. Reyes-Reyes EM, Ramos IN, Tavera-Garcia MA, Ramos KS (2016), The aryl hydrocarbon receptor agonist benzo(a) pyrene reactivates LINE-1 in HepG2 cells through canonical TGF- $\beta 1$ signaling: Implications in hepatocellular carcinogenesis. Am J Cancer Res 6, 5, 1066-1077. PMCID: PMC4889720.

356. Coufal NG, Garcia-Perez JL, Peng GE, Yeo GW, Mu Y, Lovci MT, Morell M, O'Shea KS, Moran JV, Gage FH (2009), L1 retrotransposition in human neural progenitor cells. Nature 460, 7259, 1127-1131. https://doi.org/ 10.1038 /nature08248.

357. Muotri AR, Marchetto MC, Coufal NG, Oefner R, Yeo G, Nakashima K, Gage FH (2010), L1 retrotransposition in neurons is modulated by MeCP2. Nature 468, 7322, 443446. https://doi.org/10.1038/nature09544.

358. Faulkner GJ, Billon V (2018), L1 retrotransposition in the soma: A field jumping ahead. Mob DNA 9, 22. https://doi. org/10.1186/s13100-018-0128-1.

359. Otsubo T, Okamura T, Hagiwara T, Ishizaka Y, Dohi T, Kawamura YI (2015), Retrotransposition of long inter- spersed nucleotide element-1 is associated with colitis but not tumors in a murine colitic cancer model. PLoS One 10, 2, e0116072. https://doi.org/10.1371/journal. pone. 0116072

360. Miki Y, Nishisho I, Horii A, Miyoshi Y, Utsunomiya J, Kinzler KW, Vogelstein B, Nakamura Y (1992 Feb 1), Disruption of the APC gene by a retrotransposal insertion of L1 sequence in a colon cancer. Cancer Res 52, 3, 643-645.

361. Solyom S, Ewing AD, Rahrmann EP, Doucet T, Nelson HH, Burns MB, Harris RS, Sigmon DF, Casella A, Erlanger B, Wheelan S, Upton KR, Shukla R, Faulkner GJ, Largaespada DA, Kazazian HH Jr (2012), Extensive somatic L1 retrotransposition in colorectal tumors. Genome Res 22, 12, 2328-2338. https://doi.org/10.1101/gr.145235.112.

362. Scott EC, Gardner EJ, Masood A, Chuang NT, Vertino PM, Devine SE (2016), A hot L1 retrotransposon evades somatic repression and initiates human colorectal cancer. Genome Res 26, 6, 745-755. https://doi.org/10.1101/ gr.201814.115.

363. Asch HL, Eliacin E, Fanning TG, Connolly JL, Bratthauer G, Asch BB (1996), Comparative expression of the LINE-1 p40 protein in human breast carcinomas and normal breast tissues. Oncol Res 8, 6, 239-247. PMID: 8895199.

364. Cruickshanks HA, Tufarelli C (2009), Isolation of cancerspecific chimeric transcripts induced by hypomethylation of the LINE-1 antisense promoter. Genomics 94, 6, 397-406. https://doi.org/10.1016/j.ygeno.2009.08.013.

365. Miglio U, Berrino E, Panero M, Ferrero G, Coscujuela Tarrero L, Miano V, Dell'Aglio C, Sarotto I, Annaratone L, Marchiò C, Comoglio PM, De Bortoli M, Pasini B, Venesio T, Sapino A (2018), The expression of LINE1-MET chimeric transcript identifies a subgroup of aggressive breast cancers. Int J Cancer 143, 1, 2838-2848. https://doi.org/10.1002/ijc.31831.

366. Shukla R, Upton KR, Muñoz-Lopez M, Gerhardt DJ, Fisher ME, Nguyen T, Brennan PM, Baillie JK, Collino A, Ghisletti S, Sinha S, Iannelli F, Radaelli E, Dos Santos A, Rapoud D, Guettier C, Samuel D, Natoli G, Carninci P, Ciccarelli FD, Garcia-Perez JL, Faivre J, Faulkner GJ (2013), Endogenous retrotransposition activates oncogenic pathways in hepatocellular carcinoma. Cell 153, 1, 101-111.

367. Tchénio T, Casella JF, Heidmann T (2000), Members of the SRY family regulate the human LINE retrotransposons. Nucleic Acids Res 28, 2, 411-415. PMCID: PMC102531.

368. Song MS, Rossi JJ (2017), Molecular mechanisms of Dicer: Endonuclease and enzymatic activity. Biochem J 474, 10, 1603-1618. https://doi.org/10.1042/BCJ20160759.

369. Lau CC, Sun T, Ching AK, He M, Li JW, Wong AM, Co NN, Chan AW, Li PS, Lung RW, Tong JH, Lai PB, Chan HL, To KF, Chan TF, Wong N (2014), Viral-human chimeric transcript predisposes risk to liver cancer development and progression. Cancer Cell 25, 3, 335-349. https://doi.org/10.1016/j.ccr.2014.01.030.

370. Sciamanna I, Landriscina M, Pittoggi C, Quirino M, Mearelli C, Beraldi R, Mattei E, Serafino A, Cassano A, Sinibaldi-Vallebona P, Garaci E, Barone C, Spadafora C (2005), Inhibition of endogenous reverse transcriptase antagonizes human tumor growth. Oncogene 24, 24, 39233931. https://doi.org/10.1038/sj.onc.1208562.

371. Patnala R, Lee SH, Dahlstrom JE, Ohms S, Chen L, Dheen ST, Rangasamy D (2014), Inhibition of LINE-1 retrotransposon-encoded reverse transcriptase modulates the expression of cell differentiation genes in breast cancer cells. Breast Cancer Res Treat 143, 2, 239-253. https://doi.org/ $10.1007 / \mathrm{s} 10549-013-2812-7$.

372. Rangasamy D, Lenka N, Ohms S, Dahlstrom JE, Blackburn AC, Board PG (2015), Activation of LINE-1 Retrotrans- 
poson Increases the Risk of Epithelial-Mesenchymal Transition and Metastasis in Epithelial Cancer. Curr Mol Med 15, 7, 588-597. PMCID: PMC5384359.

373. Tahara T, Shibata T, Okubo M, Kawamura T, Horiguchi N, Ishizuka T, Nakano N, Nagasaka M, Nakagawa $\mathrm{Y}$, Ohmiya N (2016), Demonstration of potential link between Helicobacter pylori related promoter $\mathrm{CpG}$ island methylation and telomere shortening in human gastric mucosa. Oncotarget 7, 28, 43989-43996. https://doi.org/10.18632/ oncotarget.9764.

374. Tahara T, Tahara S, Horiguchi N, Kawamura T, Okubo M, Yamada H, Yoshida D, Ohmori T, Maeda K, Komura N, Ikuno H, Jodai Y, Kamano T, Nagasaka M, Nakagawa Y, Tsukamoto T, Urano M, Shibata T, Kuroda M, Ohmiya N (2018), Methylation status of IGF2 DMR and LINE1 in leukocyte DNA provides distinct clinicopathological features of gastric cancer patients. Clin Exp Med 18, 2, 215220. https://doi.org/10.1007/s10238-017-0471-4.

375. Anastasiadis PZ, Moon SY, Thoreson MA, Mariner DJ, Crawford HC, Zheng Y, Reynolds AB (2000), Inhibition of RhoA by p120 catenin. Nat Cell Biol 2, 9, 637-644. https://doi.org/10.1038/35023588.

376. Bhowmick NA, Ghiassi M, Bakin A, Aakre M, Lundquist CA, Engel ME, Arteaga CL, Moses HL (2001), Transforming growth factor-beta1 mediates epithelial to mesenchymal transdifferentiation through a RhoA-dependent mechanism. Mol Biol Cell 12, 1, 27-36. https://doi.org/10.1091/ mbc.12.1.27.

377. Fleming YM, Ferguson GJ, Spender LC, Larsson J, Karlsson S, Ozanne BW, Grosse R, Inman GJ (2009), TGF-beta-mediated activation of RhoA signalling is required for efficient (V12)HaRas and (V600E)BRAF transformation. Oncogene 28, 7, 983-993. https://doi.org/ 10.1038/onc.2008.449.

378. Blaney Davidson EN, Remst DF, Vitters EL, van Beuningen $\mathrm{HM}$, Blom AB, Goumans MJ, van den Berg WB, van der Kraan PM (2009), Increase in ALK1/ALK5 ratio as a cause for elevated MMP-13 expression in osteoarthritis in humans and mice. J Immunol 182, 12, 7937-7945. https://doi.org/10.4049/jimmunol.0803991.

379. Roelen BA, van Rooijen MA, Mummery CL (1997), Expression of ALK-1, a type 1 serine/threonine kinase receptor, coincides with sites of vasculogenesis and angiogenesis in early mouse development. Dev Dyn 209, 4, 418430. https://doi.org/10.1002/(SICI)1097-0177(199708) 209:4<418::AID-AJA9>3.0.CO;2-L

380. de Vinuesa AG, Bocci M, Pietras K, Ten Dijke P (2016), Targeting tumour vasculature by inhibiting activin receptor-like kinase (ALK)1 function. Biochem Soc Trans 44, 4, 1142-1149. https://doi.org/10.1042/BST20160093.

381. Bellovin DI, Bates RC, Muzikansky A, Rimm DL, Mercurio AM (2005), Altered localization of p120 catenin during epithelial to mesenchymal transition of colon carcinoma is prognostic for aggressive disease. Cancer Res 65, 23, 1093810945. https://doi.org/10.1158/0008-5472.CAN-05-1947.

382. Tenhagen M, Klarenbeek S, Braumuller TM, Hofmann I, van der Groep P, Ter Hoeve N, van der Wall E, Jonkers J, Derksen PW (2016), p120-catenin is critical for the development of invasive lobular carcinoma in mice. J Mammary Gland Biol Neoplasia 21, 3-4, 81-88. https://doi.org/ 10.1007/s10911-016-9358-3.

383. Noren NK, Liu BP, Burridge K, Kreft B (2000), p120 catenin regulates the actin cytoskeleton via Rho family GTPases. J Cell Biol 150, 3, 567-580. https://doi.org/ 10.1083/jcb.150.3.567.
384. Yilmaz M, Christofori G (2010), Mechanisms of motility in metastasizing cells. Mol Cancer Res 8, 5, 629-642. https://doi.org/10.1158/1541-7786.MCR-10-0139.

385. Sarrió D, Pérez-Mies B, Hardisson D, Moreno-Bueno G, Suárez A, Cano A, Martín-Pérez J, Gamallo C, Palacios J (2004), Cytoplasmic localization of p120ctn and E-cadherin loss characterize lobular breast carcinoma from preinvasive to metastatic lesions. Oncogene 23, 19, 3272-3283. https://doi.org/10.1038/sj.onc.1207439.

386. Carnahan RH, Rokas A, Gaucher EA, Reynolds AB (2010), The molecular evolution of the p120-catenin subfamily and its functional associations. PLoS One 5, 12, e15747. https://doi.org/10.1371/journal.pone.0015747.

387. Ridley AJ, Hall A (1992), The small GTP-binding protein rho regulates the assembly of focal adhesions and actin stress fibers in response to growth factors. Cell 70, 389399 .

388. Bordoni R, Fine R, Murray D, Richmond A (1990), Characterization of the role of melanoma growth stimulatory activity (MGSA) in the growth of normal melanocytes, nevocytes, and malignant melanocytes. J Cell Biochem 44, 4, 207-219. https://doi.org/10.1002/jcb.240440403.

389. Lázár-Molnár E, Hegyesi H, Tóth S, Falus A (2000), Autocrine and paracrine regulation by cytokines and growth factors in melanoma. Cytokine 12, 6, 547-554. https://doi.org/10.1006/cyto.1999.0614.

390. Yang G, Rosen DG, Zhang Z, Bast RC Jr, Mills GB, Colacino JA, Mercado-Uribe I, Liu J (2006), The chemokine growth-regulated oncogene 1 (Gro-1) links RAS signaling to the senescence of stromal fibroblasts and ovarian tumorigenesis. Proc Natl Acad Sci USA 103, 44, 16472-16477. https://doi.org/10.1073/pnas.0605752103.

391. Margolis B, Skolnik EY (1994), Activation of Ras by receptor tyrosine kinases. J Am Soc Nephrol 5, 6, 12881299.

392. Grosheva I, Shtutman M, Elbaum M, Bershadsky AD (2001), p120 catenin affects cell motility via modulation of activity of Rho-family GTPases: A link between cell-cell contact formation and regulation of cell locomotion. J Cell Sci 114, Pt 4, 695-707.

393. Soto E, Yanagisawa M, Marlow LA, Copland JA, Perez EA, Anastasiadis PZ (2008), p120 catenin induces opposing effects on tumor cell growth depending on E-cadherin expression. J Cell Biol 183, 4, 737-749. https://doi.org/ $10.1083 /$ jcb. 200805113.

394. Schackmann RC, Tenhagen M, van de Ven RA, Derksen PW (2013), p120-catenin in cancer - Mechanisms, models and opportunities for intervention. J Cell Sci 126, Pt 16, 3515-3525. https://doi.org/10.1242/jcs.134411.

395. Jawhari AU, Noda M, Pignatelli M, Farthing M (1999), Upregulated cytoplasmic expression, with reduced membranous distribution, of the src substrate p120(ctn) in gastric carcinoma. J Pathol 189, 2, 180-185. https://doi.org/ 10.1002/(SICI)1096-9896(199910)189:2<180::AIDPATH414>3.0.CO;2-2.

396. Ogden SR, Wroblewski LE, Weydig C, Romero-Gallo J, O'Brien DP, Israel DA, Krishna US, Fingleton B, Reynolds AB, Wessler S, Peek RM Jr (2008), p120 and Kaiso regulate Helicobacter pylori-induced expression of matrix metalloproteinase-7. Mol Biol Cell 19, 10, 4110-4121. https://doi. org $/ 10.1091 / \mathrm{mbc} . \mathrm{E} 08-03-0283$.

397. Daniel JM, Reynolds AB (1999), The catenin p120(ctn) interacts with Kaiso, a novel BTB/POZ domain zinc finger transcription factor. Mol Cell Biol 19, 5, 3614-3623. https://doi.org/10.1128/MCB.19.5.3614. 
398. Fox DT, Peifer M (2007), Cell adhesion: separation of p120's powers? Curr Biol 17, 1, R24-R27. https://doi.org/ 10.1016/j.cub.2006.11.040.

399. Yanagisawa M, Anastasiadis PZ (2006), p120 catenin is essential for mesenchymal cadherin-mediated regulation of cell motility and invasiveness. J Cell Biol 174, 7, 1087-1096. https://doi.org/10.1083/jcb.200605022.

400. Carton I, Hermans D, Eggermont J (2003), Hypotonicity induces membrane protrusions and actin remodeling via activation of small GTPases Rac and Cdc42 in Rat-1 fibroblasts. Am J Physiol Cell Physiol 285, 4, C935-C944. https://doi.org/10.1152/ajpcell.00069.2003.

401. Moshfegh Y, Bravo-Cordero JJ, Miskolci V, Condeelis J, Hodgson L (2014), A Trio-Rac1-Pak1 signalling axis drives invadopodia disassembly. Nat Cell Biol 16, 6, 574-586. https://doi.org/10.1038/ncb2972. Erratum in: Nat Cell Biol 2015 Mar, 17, 350. https://doi.org/10.1038/ncb3123.

402. Gastonguay A, Berg T, Hauser AD, Schuld N, Lorimer E, Williams CL (2012), The role of Rac1 in the regulation of $\mathrm{NF}-\kappa \mathrm{B}$ activity, cell proliferation, and cell migration in nonsmall cell lung carcinoma. Cancer Biol Ther 13, 8, 647-656. https://doi.org/10.4161/cbt.20082.

403. Inumaru J, Nagano O, Takahashi E, Ishimoto T, Nakamura S, Suzuki Y, Niwa S, Umezawa K, Tanihara H, Saya H (2009), Molecular mechanisms regulating dissociation of cell-cell junction of epithelial cells by oxidative stress. Genes Cells 14, 6, 703-716. https://doi.org/10.1111/j.13652443.2009.01303.x.

Cite this article as: Brücher B.L.D.M \& Jamall I.S 2019. Transition from normal to cancerous cell by precancerous niche (PCN) induced chronic cell-matrix stress. 4open, 2, 14. 